\title{
13. HOLOCENE TO PLEISTOCENE PLANKTONIC FORAMINIFERA OF LEG 15, SITE 147 (CARIACO BASIN (TRENCH), CARIBBEAN SEA) AND THEIR CLIMATIC INTERPRETATION
}

\author{
Fred Rögl and Hans M. Bolli, Geology Department, Swiss Federal Institute of Technology, Zurich, Switzerland
}

\begin{abstract}
The Pleistocene to Holocene planktonic foraminifera of Site 147 in the Cariaco Basin, off the north coast of eastern Venezuela, were investigated for their ecologic significance. Characteristic species and their frequency, are plotted and the results compared with curves by Emiliani (1966) and Ericson and Wollin (1968). Several warm- and cold-water intervals are distinguished. Site 147 falls into the upper part of the Globorotalia truncatulinoides truncatulinoides Zone (approximately 320,000 years to Recent) and comprises from bottom to top the Pleistocene Globorotalia hessi (part only), Globigerina calida calida, Globigerina bermudezi and the Holocene Globorotalia fimbriata subzones. This compares with zones $\mathrm{V}$ to $\mathrm{Z}$ of Ericson and Wollin (1968).

Fifty-nine planktonic foraminiferal species and subspecies were distinguished, of which four are described as new. They are Globigerina clarkei n. sp., Globigerina megastoma cariacoensis $\mathrm{n}$. ssp., Hastigerinella riedeli n. sp., and Globorotalia bermudezi $\mathrm{n}$. sp. Neogloboquadrina blowi is introduced as a new name for Globigerina subcretacea Chapman. Variability and details of wall structures of the well-preserved planktonic foraminifera are illustrated by scanning electron micrographs.
\end{abstract}

Abstract

Introduction

Hydrological Setting

Paleoecological Investigations

Working Method

Ecology of characteristic planktonic foraminifera

Observations on Site 147

Paleoclimatic Interpretation of Site 147

Climatic Zonation and Correlation

Climatologic Zonation of Site 147

\section{CONTENTS}

Biostratigraphic Zonation of Site 147 Systematics $\quad 561$ Globigerinidae $\quad 561$ Globigerininae $\quad 562$ Hastigerininae $\quad 566$ Globorotaliidae $\quad 567$

Remarks on other faunal and floral components in Site 147 residues $\quad 572$ Acknowledgments $\quad 573$

References $\quad 573$

\section{INTRODUCTION}

The purpose of the Leg 15 Site 147 was to investigate the sediments of the Cariaco Basin, a small basin in the Caribbean Sea, situated along the north coast of eastern Venezuela. This basin is about $160 \mathrm{~km}$ long in an east-west direction, is about $60 \mathrm{~km}$ wide, and has a maximum depth of some 1400 meters. It is cut off from the open Caribbean Sea by a sill having an average depth of approximately 100 meters. The deepest passage is 146 meters near Farallon Centinella (Figure 1). This barrier prevents the exchange of deep water between the trough and the open sea. Together with the low freshwater inflow, it is largely responsible for the euxinic bottom conditions and the particular faunal population. The basin is divided by a north-south saddle into an eastern and western partial-basin. Site 147 is situated in a water depth of 892 meters near the saddle on the northern slope of the Western basin at $10^{\circ} 42.48^{\prime} \mathrm{N}$; $65^{\circ} 10.48^{\prime} \mathrm{W}$.

Site 147 was continuously cored to 162 meters and recovered Holocene and late Pleistocene sediments exceedingly rich in well preserved planktonic faunas including foraminifera. The 18 cores recovered 119.2 meters of sediments (recovery rate $74 \%$ ). Additional holes - 147A and B - were drilled at the same location for geochemical purposes.

The rich and well-preserved planktonic foraminifera of this extraordinarily thick recent to young Pleistocene section proved most suitable for detailed systematic and ecologic investigation, and for attempting paleoclimatic interpretations and correlation with published data of the Caribbean and Atlantic. 


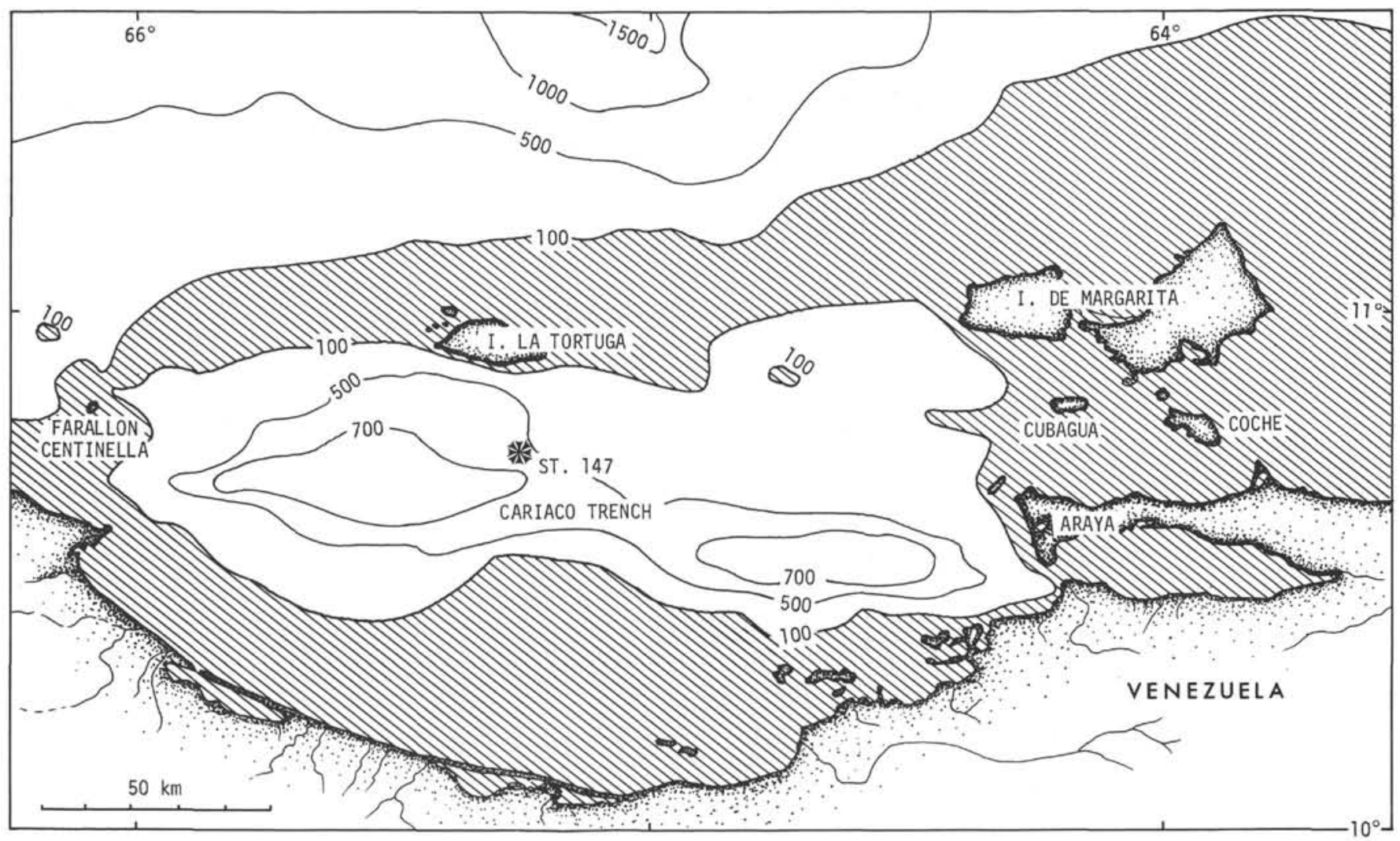

Figure 1. Cariaco Basin and location of Site 147 (from Mapa Batimetrico de la Rep. de Venezuela, III Congr. Geol. Venezolano, 1959, and after Richards and Vaccaro, 1956). Depth is in fathoms.

Some of the Recent Cariaco Basin planktonic foraminifera are included in the papers of Bermudez (1961), Bermudez and Bolli (1969), Seiglie (1963), and Seiglie and Bermudez (1963).

The figured specimens are deposited at the Museum of Natural History, Basel, under the numbers NMB C 26943-27226 and C 27621-27622.

\section{HYDROLOGICAL SETTING}

The hydrographical and chemical investigations in the southern Caribbean Sea illustrate a number of different factors which influence the ecology in the Venezuelan offshore area (Richards and Vaccaro, 1956; Richards, 1960; Gade, 1961). Because the Cariaco Basin is isolated from the open Caribbean by a sill, water circulation below sill depth is not possible and anaerobic conditions prevail from 475 meters to the bottom. The highest elevations of the ridge surrounding the Cariaco Basin consist of an arch of islands with Farallon Centinella, Tortuga, Margarita, Cubagua, Coche and the Araya penninsula (Figure 1); the deepest passage is near Farallon Centinella, 146 meters below sea level.

Isolation of the Cariaco water mass causes dissolved oxygen to decrease to zero at 475 meters. Hydrogen sulfide increases from there to the bottom. Temperature and salinity figures also show the abnormal conditions. The temperature decreases from surface values of $24^{\circ}$ to $26^{\circ} \mathrm{C}$ to $18^{\circ} \mathrm{C}$ at sill depth, and stays constant at $17^{\circ} \mathrm{C}$ from 460 meters to the bottom. The surface salinity varies from $35.28 \%$ in December (end of rainy season) to $36.57^{\circ} \%$ o in February; at 180-meter depth it is a constant $36.33 \%$ \%
From there to 520 meters the salinity decreases very slowly and remains constant at $36.20 \%$ from 520 meters to the bottom. North of the Basin, in the open Caribbean, the values of temperature and salinity in the upper layers are the same as in the Cariaco Basin, but they drop to $8.6^{\circ} \mathrm{C}$ and $34.91 \%$, respectively, at 488 meters.

The planktonic foraminifera living close to the surface are not influenced by these peculiar conditions. But deep-water forms, such as Sphaeroidinella dehiscens, flourishing at depths greater than 500 meters, and common outside the trough, are very scarce in the Cariaco Basin sediments.

The surface conditions in the Cariaco Basin are influenced by a number of different water masses. Strong upwelling of cold water along the north coast of Venezuela gives rise to a planktonic foraminiferal population that is different from that of the open Caribbean Sea. For instance, Globigerina bulloides is frequent in coastal waters but scarce in the warmer open Caribbean.

\section{PALEOECOLOGICAL INVESTIGATIONS}

\section{Working Method}

The planktonic foraminifera of at least one sample from each section of the cores were investigated in detail. Additional samples were checked for possible faunal changes within the core (about 110 samples from Site 147). The samples were washed through U.S. standard sieves and the following fractions used: $0.420 \mathrm{~mm}, 0.177 \mathrm{~mm}$, and 0.063 $\mathrm{mm}$. The fraction larger than $0.177 \mathrm{~mm}$ was selected for 
the statistical work. Depending on available material, 400 to 1900 (average 800) specimens from each sample were determined specifically.

A comparison with sample intervals used in Emiliani (1966) and Ericson and Wollin (1968), based mainly on piston cores, shows that coverage of the section at Site 147 is comparable since the rate of sedimentation in the Cariaco Basin is 20 to 50 times higher than in those sections.

To obtain a curve representing the presumed climatic changes in the examined sections, typical species were selected and their percentages of the total fauna were determined (Table 1). The selected cold water forms are Globigerina bulloides s.1., Globorotalia inflata, Neogloboquadrina pachyderma pachyderma and $N$. pachyderma incompta. Those indicative of warm water are Globigerinoides ruber, $G$. trilobus sacculifer and the Globorotalia cultrata-menardii-tumida group. The ratio of three typical warm-water species against important cold and warm water species as expressed by the formula

G. ruber + G.t. sacculifer + G. menardii-group

G. ruber + G.t. sacculifer $+G$. menardii-group

$+G$. bulloides $+N$. pachyderma $+G$. inflata

is shown in the far right column ("warm-water indicators") of Table 1.

For correlation with published temperature curves as shown on Figure 2, only the G. menardii-tumida group and percentage of warm-water indicators were used. For their climatic studies Ericson and Wollin (1968) used only the $G$. menardii-tumida group, which, however, occurs only sporadically at Site 147. Additional species were therefore included. A value of less than 10 percent of warm-water forms is regarded as indicating a cold environment, and a rise above 80 percent a warm one.

Gaps in the climatic curve of Site 147, in the top 60 meters are due to incomplete core recovery. From 60 meters to bottom, recovery was practically complete.

In addition to this quantitative work, all fractions, including the finest, were investigated for additional planktonic foraminiferal species and for other microfossils.

\section{Ecology of Characteristic Planktonic Foraminifera}

The pertinent data for climatologic analysis were obtained from publications dealing with the ecology of planktonic foraminifera (Bé, 1960, 1969; Bé and Tolderlund, 1971; Boltovskoy; 1969; Bradshaw, 1959; Cifelli, 1971; Zobel, 1971).

Cifelli (1971) shows that the distribution of planktonic species is controlled by more than temperature. Other factors, such as salinity, upwelling, or distribution of water masses are also of significance. This is confirmed by Zobel (1971) on the distribution of Globigerinoides ruber and $G$. trilobus sacculifer in the Arabian Sea. The distribution of these two tropical to subtropical species is apparently controlled also by salinity (Bé and Tolderlund, 1969). Optimal conditions for $G$. trilobus sacculifer seem to exist at salinities of 34.5 to $36.0 \%$ and for G. ruber at either higher or lower values. This may be the reason for the scarcity of $G$. trilobus sacculifer in the Cariaco Basin, where the average salinity is somewhat above $36^{\circ} \%$.
Changes in temperature are here regarded as being expressed in the irregularities of the faunal composition. A paleoclimatologic analysis of the sections by a grouping of the species that are abundant and characteristic of certain water temperatures is therefore feasible. Seasonal variations of the number of specimens present can be ignored because the vertical thickness of samples used measures about $2 \mathrm{~cm}$, which represent approximately 40 years of sedimentation.

Glacial periods during the Pleistocene did not sufficiently lower the water temperature in the central part of the Caribbean Sea to permit the entry of subpolar faunas. Only the upwelling of colder water masses, still active today, can explain the presence of colder water (transitional to subpolar) forms along the coastal area including the Cariaco Basin.

Association of the planktonic foraminifera at Site 147 ranges from temperate to tropical in character.

\section{Indicators of Cooler Waters}

Globigerina bulloides: This species appears to be the best marker for cooler intervals in the investigated samples of Site 147. It is complementary in its occurrence to Globigerinoides ruber, which is a distinct warm-water form. The maximum occurrence of Recent Globigerina bulloides is in subpolar waters, extending also into temperate and subtropical areas.

Neogloboquadrina pachyderma-incompta is treated here as one group and subdivided only on the direction of coiling. Left coiling $N$. pachyderma pachyderma, representing the extreme cold-water form, occurs in Site 147 but only in a few samples and in small numbers. Abundant in the sections are dextrally coiled specimens of $N$. pachyderma incompta, known from subpolar to temperate waters.

Globorotalia inflata is not a pronouncedly cold-water form but is complementary in its occurrence to the Globorotalia menardii-tumida group. The value of the species for climatic interpretation is somewhat restricted because of its apparent optimal development at different temperatures, as was shown by Cifelli (1971).

\section{Indicators for Warm Waters}

Globigerinoides ruber is characteristic of subtropicaltropical areas, but its optimal occurrence is also dependent on salinities above the $36.0^{\circ} \%$ or below $34.5^{\circ} \%$. G. ruber is regarded as one of the most useful climatic indicators in Site 147.

Globigerinoides trilobus sacculifer occurs in identical temperature ranges as $G$. ruber but in salinity ranges between 34.5 and $36.0^{\circ} \%$; the interval not suitable for $G$. ruber. The species is scarce at Site 147.

Globorotalia menardii-tumida group: Here are included G. cultrata, G. fimbriata, G. menardii, G. tumida tumida, and $G$. tumida flexuosa. All are typical for tropicalsubtropical waters, $G$. tumida s.l. being confined to the warmest areas. Ericson and Wollin (1968) used this group of species for their climatologic curve.

There are other species, but of lesser significance, than these two groups of distinct climatic indicators. The depth and temperature ranges of some are taken from the literature, as shown on Figure 3. 
TABLE 1

Selected Species as Percentage of Total Planktonic Foraminiferal Fauna and Relationship of Cold-and Warm-Water species

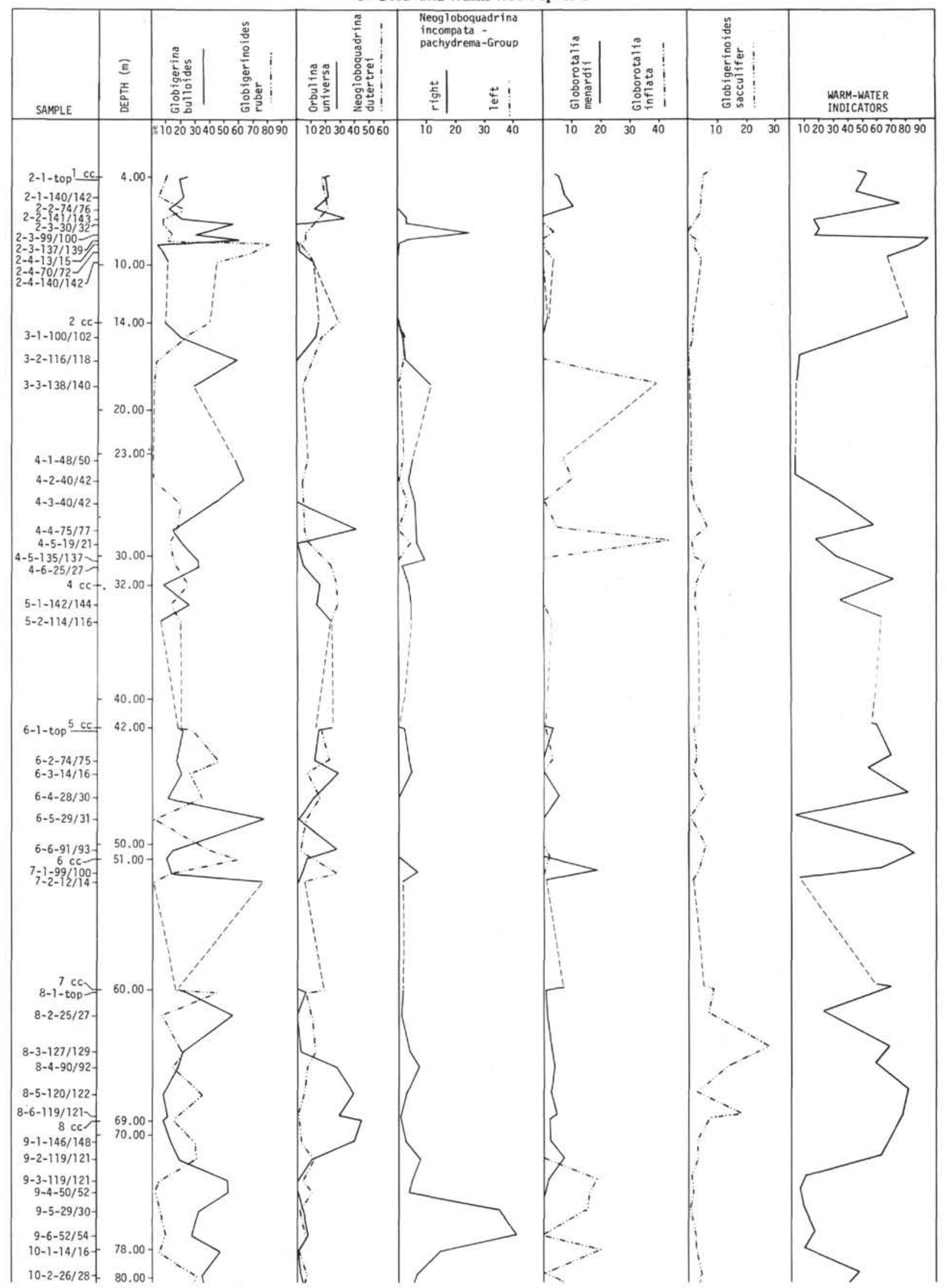


TABLE 1 - Continued

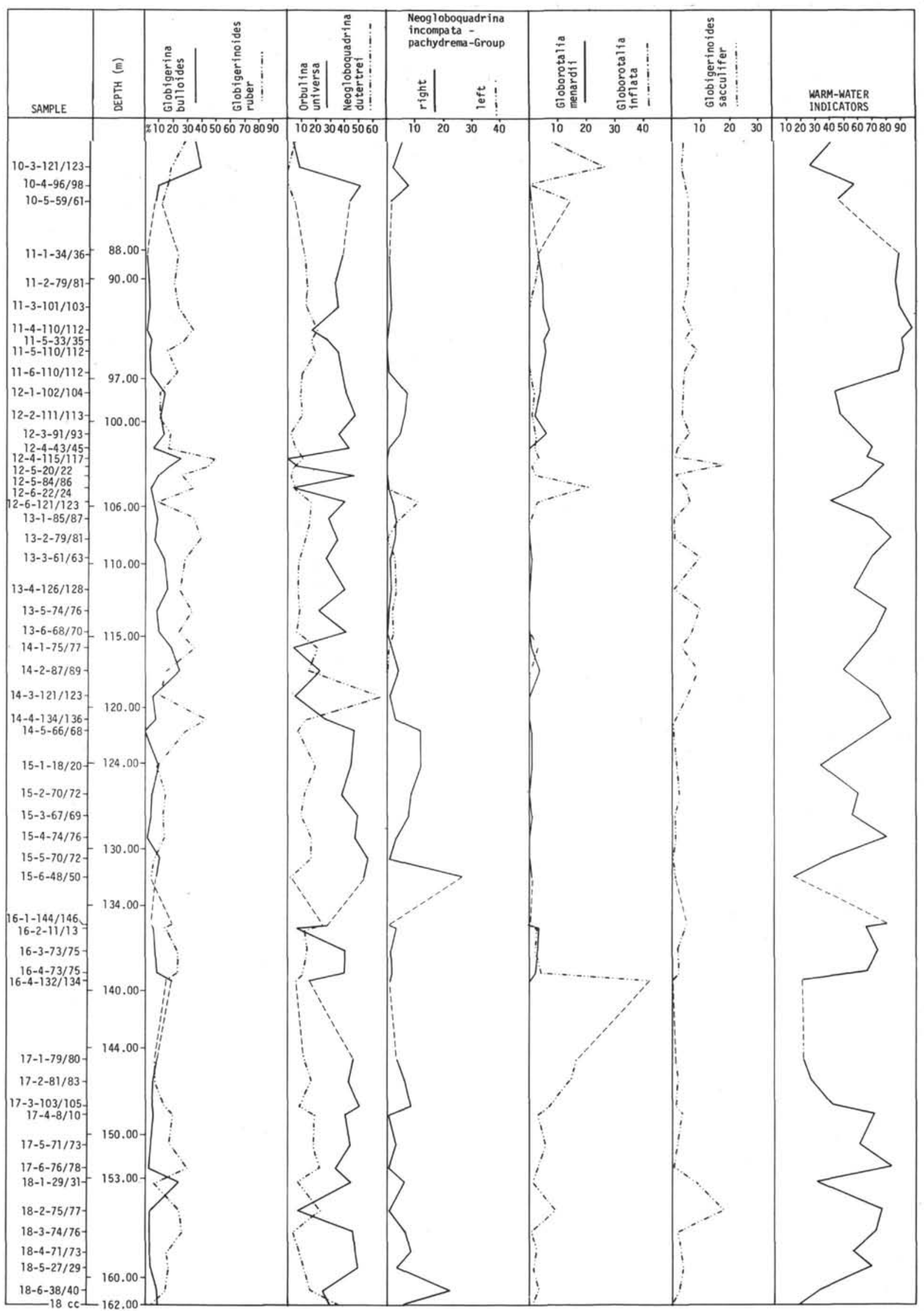


F. RÖGL, H. M. BOLLI

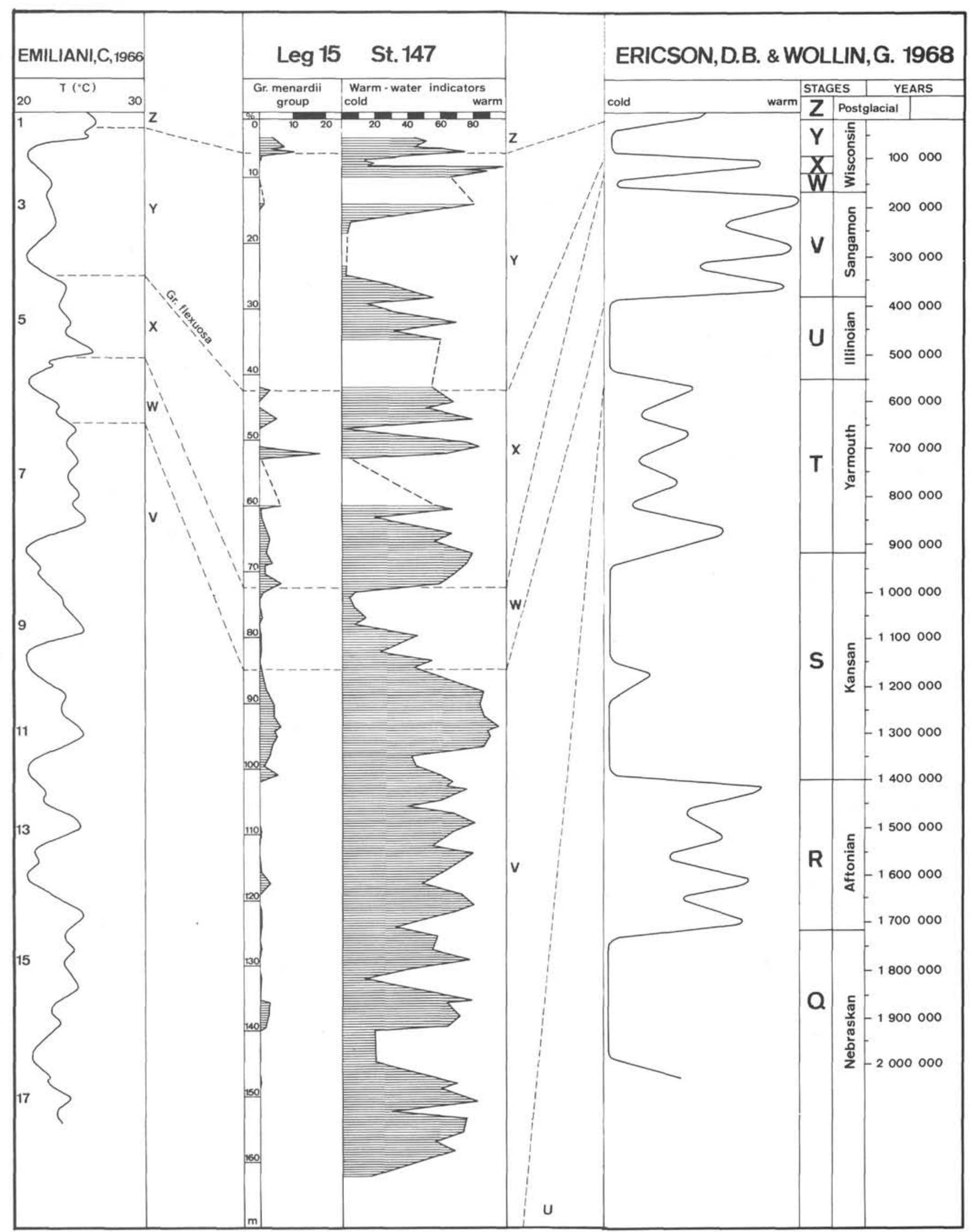

Figure 2. Climatological interpretation of the planktonic foraminifera in Site 147 and the correlation with the standard - curves of C. Emiliani (1966) and D. B. Ericson and G. Wollin (1968). 


\begin{tabular}{|c|c|c|c|c|c|c|c|c|c|}
\hline & $\begin{array}{l}a \\
\overleftarrow{4} \\
0 \\
0\end{array}$ & $\begin{array}{l}\alpha \\
\stackrel{\alpha}{1} \\
\overrightarrow{0} \\
0 \\
0 \\
\infty \\
D \\
\sim\end{array}$ & 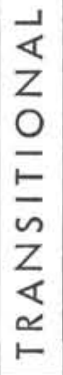 & 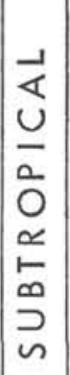 & 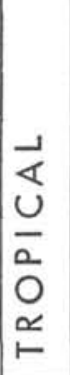 & ir & $\mathrm{C}^{\circ}$ & \multicolumn{2}{|r|}{ DEPTH } \\
\hline $\begin{array}{l}\text { Neogloboquadrina pachyderma } \\
\text { pachyderma, sinistrally coiling }\end{array}$ & & & & & & $0-9$ & 2 & & $500-2000$ \\
\hline Globigerinita uvula & & & & & & & & & \\
\hline Globorotalia cavernula & - & & & & & $4-6$ & & $0-1000$ & $0-250$ \\
\hline Globigerina quinqueloba & - & & & & & $1-21$ & $\begin{array}{l}1-5 \\
11-18\end{array}$ & & \\
\hline $\begin{array}{l}\text { Neogloboquadrina pachyderma } \\
\text { pachyderma, dextrally coiling }\end{array}$ & & & - & & & $10-18$ & & & $500-2000$ \\
\hline $\begin{array}{l}\text { N. pachyderma f. superficiaria } \\
(=N \text {. pachyderma incompta) }\end{array}$ & & & - & & & & & $0-500$ & \\
\hline Globigerina bulloides & & & - & - & & $0-27$ & $3-19$ & $0-1000$ & $250-1000$ \\
\hline Globorotalia inflata & & - & - & - & & $1-27$ & $\begin{array}{c}2-6 \\
13-19\end{array}$ & $0-100$ & \\
\hline Globorotalia truncatulinoides & & - & - & - & & $4-27$ & $17-22$ & & \\
\hline Orbulina universa & & & & & 一 & $10-30$ & $\begin{array}{l}12-1 / \\
17-23\end{array}$ & $0-100$ & \\
\hline Globigerina calida & & & & & - & $15-33$ & & & \\
\hline Globigerinita glutinata & - & - & - & & - & & & $0-750$ & \\
\hline Hastigerina pelagica & & - & - & & - & $7-29$ & $20-26$ & 01000 & deep \\
\hline Globorotalia crassaformis & & & - & & - & $16-27$ & & $0-1500$ & 100 \\
\hline Neogloboquadrina dutertrei & & & - & & & $9-30$ & $16-24$ & $0-750$ & 250 \\
\hline Globigerinoides conglobatus & & & - & & & $15-30$ & $21-29$ & $0-250$ & \\
\hline Globorotalia menardii - group & & & - & & & $16-30$ & $20-25$ & $0-1000$ & $500-1000$ \\
\hline Globigerinella siphonifera & & & & & & $12-30$ & $19-28$ & $0-750$ & $0-250$ \\
\hline Pulleniatina obliquiloculata & & & & & & $19-30$ & $22-24$ & & \\
\hline Globigerinoides ruber & & & & & & $14-30$ & $21-29$ & $0-700$ & $0-100$ \\
\hline Globigerinoides sacculifer & & & & & & $15-30$ & $24-30$ & $0-1000$ & $50-100$ \\
\hline Globorotalia tumida & & & & - & & $19-31$ & $29-31$ & & \\
\hline
\end{tabular}

Figure 3. Ecologic distribution of selected planktonic foraminifera (after Bé, 1967, 1969; Bé and Tolderlund, 1971; Boltovskoy, 1969). 


\section{Observations on Site 147}

Due to the peculiar hydrological conditions in the Cariaco Basin, tests of planktonic animals are strongly predominant in the sediments, with planktonic foraminifera forming the largest part. Also frequent are planktonic living larval stages of benthonic molluscs, pteropods, and fish debris. Radiolaria are present in some samples. Ostracods are present, as well as sclerites and fragments of siliceous sponges, corals, and echinoderms. Benthonic foraminifera mostly Bolivinas and other dwarfed specimens - make up a negligible portion of the foraminiferal fauna. Postlarval stages of molluscs were present but scarce. They may possibly have been carried in along with some large-sized benthonic foraminifera from the shallower and better aerated areas of the trough.

Fine quartz detritus was found in only one sample (Core 14 , Section 4, 134-136 cm). No other indication exists for transportation or reworking in the material of Site 147. The distribution of Recent sediments and planktonic foraminiferal faunas in the Cariaco Basin are illustrated in the investigations of Miro (1971) and Miro and Orell (1971).

Remarkable is the rich occurrence of Diatomeae at two levels (Core 2, Section 3, 30-101 cm and Core 6, Section 5, $29-31 \mathrm{~cm})$, both within cold-temperature intervals.

The characteristic red color in Globigerinoides ruber and Globigerina rubescens is particularly strong from the top to Core 6, gradually becoming weaker from there to Core 12, Section 4. Levels exist within this interval where the species have no red coloring. These levels seem to coincide with cold-temperature intervals, which agrees with investigations in the Recent, where noncolored Globigerinoides ruber occur in colder water (Boltovskoy, 1969; Be and Tolderlund, 1971).

Pyrite and gypsum occur as fillings of foraminiferal tests or as crystal aggregates in several samples, but these two minerals are only rarely found together. A relation of these minerals with climatic changes could not be established with certainty, but pyrite seems to have a certain preference for temperate climates. Though no clear trend could be seen for gypsum, it would appear that, in general, gypsum shows a preference for colder intervals but is often also present with warm-water faunas. One reason for the formation of gypsum may be the stronger isolation of the Cariaco Basin from the open Caribbean due to lowering of the sea level in colder periods, causing lagoonal conditions with increased salinity.

\section{PALEOCLIMATIC INTERPRETATION OF SITE 147}

The uppermost samples available (Core 1, core catcher to Core 2, Section 1, 140-142 cm, to $5.42 \mathrm{~m}$ ) contain a fauna of planktonic foraminifera with about 50 percent warm-water forms, comparable to that living today in the Cariaco Basin, and corresponding to a surface temperature of $24^{\circ}$ to $26^{\circ} \mathrm{C}$.

The interval immediately below (Core 2, Section 2, 20-22 cm to Core 2, Section 2, 74-76 cm, 5.70-6.26 m) shows a period of warmer water with about 60 to 75 percent warm-water forms. It probably corresponds to the warm period of the early Holocene.

The Samples Core 2, Section $2(141-143 \mathrm{~cm})$ to Core 2, Section $3(137-139 \mathrm{~cm})(6.91-8.39 \mathrm{~m})$ indicate a fairly distinct lowering of temperature, but still with 15 to 35 percent warm-water forms.

This is underlain by a section indicating warm conditions, from Core 2, Section $3(147-149 \mathrm{~cm})$ to Core 2, Section $4(140-142 \mathrm{~cm})(8.47-9.92 \mathrm{~m})$, containing up to 98 percent warm-water forms.

After a sampling gap from 9.92 meters to 14.00 meters, there is a gradual lowering of the temperature to Sample Core 3, Section $1(100-102 \mathrm{~cm})(15.02 \mathrm{~m})$. The Samples Core 3, Section $2(116-118 \mathrm{~cm})$ to Core 4, Section 2 (40-42 $\mathrm{cm})(16.66-24.92 \mathrm{~m}$, with a gap from $18.40-23.48 \mathrm{~m})$ have mainly cold-water faunas, and only 3 to 6 percent of warm-water aspect.

Moderate temperatures with some intermittent tendencies for cooling are indicated from Core 4, Section 3 (40-42 $\mathrm{cm})$ to Core 5, Section $2(114-116 \mathrm{~cm})(26.40-34.66 \mathrm{~m})$. A sample gap exists from 34.66 to 42.00 meters.

The presence of Globorotalia tumida flexuosa in Core 6, Section 1, top $(42.00 \mathrm{~m})$ represents an important stratigraphic and climatic level.

An extended warm-water interval with short but distinct cold interruptions follows from Core 5, core catcher to Core 9, Section $2(119-121 \mathrm{~cm})(42.00-71.71 \mathrm{~m})$, with a sample gap from 52.46 to 60.00 meter.

A second very cold interval with only 5 to 9 percent warm-water forms lies between Core 9, Section 3 (119-121 $\mathrm{cm})$ and Core 10, Section $1(14-16 \mathrm{~cm})(73.19-78.16 \mathrm{~m})$. A longer warm period in this section ranges from Core 11, Section $1(3436 \mathrm{~cm})$ to Core 11 , Section $6(110-112 \mathrm{~cm})$ (88.34-96.62 m), with 85 to 95 percent warm-water forms. The interval from 79.76 to 84.61 meters shows an intermediate temperature range.

The curve follows an irregular course within the moderately warm to warm range of 40 to 80 percent warm-water forms from 98.02 meters to the bottom of the section. Some colder fluctuations are indicated in Core 15, Section $6(48-50)(132.00 \mathrm{~m})$ and Core 16 , Section 4 $(132-134 \mathrm{~cm})$ to Core 17 , Section $2(81-83 \mathrm{~cm})$ $(139.82-146.33 \mathrm{~m})$. The bottom sample (Core 18, core catcher, at 162.00 meters) is again indicative of a cooling period.

\section{CLIMATIC ZONATION AND CORRELATION}

The foraminiferal percentage curve of Site 147 is compared on Figure 3 with the standard curves for marine Pleistocene climatology of the Caribbean and Atlantic area by Emiliani (1966), and Ericson and Wollin (1968). The curve of Emiliani (1966) is based on $\mathrm{O}^{18 / \mathrm{O}^{16}}$ paleotemperature determinations compared with some faunal changes within the Globorotalia menardii group and also of Globigerinoides ruber, G. conglobatus, G. sacculifer, and some other planktonic species (Emiliani, 1969). Ericson and Wollin's (1968) curve, based only on the Globorotalia menardii-tumida group, provides a clear though greatly simplified picture.

Some difficulties in our investigations arose from the almost complete deficiency of detailed faunal investigations in the Late Pleistocene. Only one well-established Late Pleistocene datum is known so far for the Caribbean/ Atlantic; that is the extinction level of Globorotalia tumida flexuosa at the top of stage 5 (flexuosa Zone) of Emiliani 
(1966), and in Zone X of Ericson et al. (1961). The last occurrence of this subspecies in Site 147 is in Core 6, Section 1 (top) (42.00 m). This extinction of Globorotalia tumida flexuosa can apparently be taken as a fairly reliable correlation level.

Another event is the extinction of Globorotaloides hexagonus in the Atlantic, where the last scarce specimens also occur in Zone X of Ericson et al. (1961).

\section{Climatologic Zonation of Site 147}

Zones V to Z of Ericson et al. (1961 and 1968), could be recognized in Site 147 as well as stages 1 through 7 of Emiliani (1966). The lower part of the Site 147 section cannot be clearly correlated with Emiliani's stages.

Zone $\mathbf{Z}$ (stage 1,0 to $6.26 \mathrm{~m}$ ): The post-glacial interval (11,000 years to Recent, according to Wollin, et al., 1971) can readily be correlated. It is characterized by the occurrence of Globorotalia cultrata fimbriata and Globorotalia cultrata (= modern G. menardii of Emiliani, 1969). This correlation is also confirmed by the determination of an absolute age of 11,000 years on a nearby piston core at 8.4 meters (Heezen et al., 1959).

Zone Y (stage 1, lower part, to stage $4 ; 6.91$ to 42.00 $\mathrm{m})$ : The top of the zone is characterized by a short cooling period to 8.37 meters, corresponding with the short cooling in stage 1 of Emiliani. A warmer section underlies it to 15.00 meters, the first warming of stage 1. Corresponding with stage 2 is the exceptionally cold period of 16.66 to 24.92 meters. Temperatures are assumed to have been fluctuating between 24.92 meters and 34.66 meters, an interval that corresponds with Emiliani's stage 3. A recovery gap between 34.66 meters and 42.00 meters might be equivalent to Emiliani's cold stage 4 .

Zone X (stage 5, 42.00-71.71 m): This zone is characterized by the extinction of Globorotalia tumida flexuosa at its top and by the abundance of this subspecies together with $G$. tumida tumida and small-sized $G$. menardii. The last scarce specimens of Globorotaloides hexagonus occur in this interval. Globigerina calida calida first occurs near the base of this zone, which allows a correlation with Blow's (1969) Globigerina calida calidaSphaeroidinella dehiscens excavata Zone boundary. This interval is climatically warm, but is interrupted by short, very cool periods.

Zone W (stage 6;73.19-84.61 m): This represents a distinctly cold period of fairly short duration, characterized by a small-sized fauna. Globigerina bermudezi appears here. A second absolute age determination at 75 meters by Broecker (this volume) gives 150,000 years. This is in good agreement with Zone W of Ericson and Wollin.

Zone V (stage 7-?; 88.34-162.00 m): This zone begins with a long and distinct temperature maximum from 88.34 to 96.62 meters that corresponds to stage 7 . With its moderate temperatures, the zone becomes somewhat indistinct in its lower part and consequently correlation with Emiliani's curve (that fluctuates between stages 8 and 15) is difficult.

By extrapolation of the sedimentation rate of about 50 $\mathrm{cm} / 10^{3} \mathrm{y}$ in the upper part of the section, Site 147 has a total age range of some 320,000 years and thus does not extend to the base of Zone V.

\section{BIOSTRATIGRAPHIC ZONATION OF SITE 147}

Some of the climatologic boundaries found at Site 147 can be correlated with biostratigraphic zones. The entire section is part of the Globorotalia truncatulinoides truncatulinoides Zone, ranging from Pleistocene to Holocene (Bolli, 1970). The subdivision of this zone into subzones is proposed by Bolli (this volume) with reference to several Caribbean sites, including Site 147.

Globorotalia fimbriata Subzone (0-6.26 m; Core 2, Section 2, 74-76 cm): Corresponds to Zone $\mathrm{Z}$ or the Holocene, characterized by the range of Globorotalia fimbriata. Also characteristics is the occurrence of thinwalled and flattened specimens of Globorotalia cultrata.

Globigerina bermudezi Subzone (6.91-42.00 m; Core 2, Section 2, 141-143 cm to Core 5, core catcher): Equals Zone Y. This is the interval between the top of Globorotalia tumida flexuosa and the first occurrence of Glororotalia fimbriata. This subzone has no special marker and was named after Globigerina bermudezi which is common in sediments of Site 147, but is not restricted to the subzone and is still living.

Globigerina calida calida Subzone (42.00-69.00 m; Core 6 , Section 1, top to Core 8 , core catcher): The subzone ranges from the first occurrence of Globigerina calida calida to the extinction of Globorotalia tumida flexuosa. It is only part of the Globigerina calida calida-Sphaeroidinella dehiscens excavata Zone of Blow (1969), and corresponds to the larger part of Zone X and is therefore of Late Pleistocene age. Globorotaloides hexagonus has its last occurrence in this zone.

Globorotalia hessi Subzone (70.46-162.00 m; Core Bl. 9, Section 1, 146-148 $\mathrm{cm}$ to bottom of section): The subzone extends from the first occurrence of the zonal marker to the first appearance of Globigerina calida calida. The subzonal marker is absent in Site 147, but the top of the subzone is determined by the first occurrence of Globigerina calida calida. Globigerina bermudezi appears in the upper part of this zone. At Site 147, the subzone includes the lowermost part of Zones X, W, and V.

Globorotalia crassaformis viola Subzone: This is the lowest of the four Pleistocene subzones, with its marker becoming extinct at the base of the Globorotalia hessi Subzone. The marker is absent in Site 147; thus it may be concluded that the site bottomed within the Globorotalia hessi Subzone.

\section{SYSTEMATICS}

Many authors (Bolli, Loeblich and Tappan, 1957; Banner and Blow, 1959 and 1960; Loeblich and Tappan, 1964; Blow, 1965; El Naggar, 1971) have based the classification of planktonic foraminifera on the test morphology alone. To avoid resulting inconsistancies, some (Parker, 1962; Lipps, 1966; Bé, 1967) made an attempt to arrive at a more natural system in that they regarded the wall structure as of primary systematic importance. An attempt is made in the following to select from the two systems the criteria essential for the classification.

\section{Family GLOBIGERINIDAE Carpenter, Parker and Jones, 1862}

Characterized by a perforate wall and the possession of long and massive spines which are present at least during the earlier part of the ontogeny. In contrast, the family Globorotaliidae does not 
possess spines. Where the spines are lost in the adult stage, their base may become covered by secondary calcite incrustations. The spines are clearly separated from the material of the chamber wall and begin, as a rule, to grow on the primary membrane and are surrounded at the base by a cuff of plate-shaped calcite crystals. Those of older chambers may penetrate through the walls of the younger ones. Only exceptionally are the spines directly attached on the chamber wall. These features are discussed by, for example, Be (1965), Hemleben (1969), and Bé and Hemleben (1970). In the cross section, the spines may be circular, triangular, or triradiate. Tests are trochospiral, streptospiral, planispiral, or spherical; chambers are globular, oviform, or clavate; walls are smooth and rough to cancellate. The position of primary aperture is umbilical, extraumbilical, or spiroumbilical; secondary apertures are possible.

\section{Subfamily GLOBIGERININAE Carpenter, Parker and Jones, 1862}

As the family definition but with the following restrictions: test trochospiral or spherical involute, chambers globular to oviform. The position of the primary aperture is umbilical, sometimes also extraumbilical to spiroumbilical. Secondary apertures may occur. The spines are circular to triangular in cross section.

\section{Genus GLOBIGERINA d'Orbigny, 1826}

As for the subfamily definition but with the following restrictions: test trochospiral, primary aperture umbilical, sometimes also extending extraumbilically. Without secondary apertures.

\section{Globigerina bermudezi Seiglie, 1963}

(Plate 2, Figure 11-19; Plate 2, Figure 4)

1963 Globigerina bermudezi-Seiglie, G.A., Bol. Inst. Oceanogr., Univ. Oriente, 2 (1), p. 90 , pl. 1, fig. 1-8.

The form shows much variation. The first one and a half to two low trochospiral whorls are similar to Globigerina bulloides s.l., however, the last few chambers are narrower and show typical umbilical extensions. The umbilicus is wide and large, the shape of the aperture variable. Typical specimens (Plate 2, Figures 11-13, 15) possess a wide final chamber, distinctly elongated in spiro-umbilical direction, with a large low arched umbilical - extraumbilical aperture. The final, occasionally also the penultimate aperture. The final, occasionally also the penultimate chamber, may become partially detached (Plate 2, Figures 14, 16-19), which results in a distinct size increase and a more variable shape of the aperture. This partial detachment may also extend to the spiral side, where large and irregular shaped secondary apertures may be formed fairly frequently. The wall structure is similar to that of Globigerina bulloides bulloides, but mostly somewhat more delicate and with larger pores.

The form is present in Site 147 from top to Core 10, Section 5 $(59-61 \mathrm{~cm})$ which coincides with the lower boundary of Zone W of Ericson and Wollin (1968). It is living today in the Cariaco Basin. Ancestral forms with umbilical apertures with the tendency to become extraumbilical and partially detached and widened final chamber (Plate 1, Figure 21; Plate 2, Figure 18) reach down to Core 16 , Section $1(144-146 \mathrm{~cm})$.

\section{Globigerina bulloides - group}

The test consists basically of a fairly low trochospire with four globular chambers in the last whorl. The variability of this group is considerable and gave rise to the erection of a number of separate but obviously closely related species. To indicate the close relationship they are all treated here as subspecies of Globigerina bulloides.

Compared with the central type, Globigerina bulloides quadrilatera is characterized by a reduced final chamber, Globigerina bulloides umbilicata by an increase in the number of chambers. Globigerina bulloides riveroae differs by having a larger size and slightly extraumbilical position of the aperture. The variability within Globigerina bulloides bulloides is restricted to the size of aperture, wall thickness, and more or less compact arrangement of chambers.

It would appear that occurrence and distribution of the various subspecies depends on ecologic factors, mainly temperature. The more compact Globigerina bulloides bulloides, with thick wall and small aperture, is apparently largely restricted to colder waters, while forms with more delicate walls, larger apertures, and chambers arranged more loosely are indicative of temperate conditions, which are also preferred by the more loosely coiled Globigerina bulloides umbilicata. It is likely that factors other than temperature, still to be determined, play a role in the distribution of the Globigerina bulloides subspecies.

Globigerina bulloides bulloides d'Orbigny, 1826

(Plate 1, Figures 1-9 and 11; Plate 12, Figures 1 and 8)

1826 Globigerina bulloides - d'Orbigny, A., Ann. Sci. Nat., 7, p.

277, no. 1.1960 Globigerina bulloides d'Orb. - Banner, F.T. and

Blow, W.H., Cushm. Found. Foram. Res. Contr., 11, p. 3, pl. 1, fig. 1, 4 (lectotype).

Shape of test low trochospiral; four chambers per whorl, increasing regularly in size. Wall with small regularly distributed pores and thin spines with circular cross section in between. At the base the spines are surrounded by plate shaped crystals. Forms with distinctly incised sutures and large, semicircular apertures are frequent (Plate 1, Figures 1-4, 5-7). Lower down in the section of Site 147 , and in intervals of colder water, chambers are less distinctly separated by sutural incisions, apertures are less highly arched, and the walls are thicker (Plate 1, Figures 8-9). Another variation of aperture is shown on Plate 1, Figure 11, by a form with a large final chamber and low arched aperture.

Very large sized Globigerina may possess secondary apertures on the spiral side. However these cannot be directly compared with those in Globigerinoides, because they are mostly of irregular shape and appear at random. In Globigerina bulloides bulloides such secondary apertures are comparatively rare (Plate 1, Figure 3 ), they are more frequent in the large, more loosely coiled forms, such as Globigerina bulloides umbilicata.

Globigerina bulloides cf. quadrilatera Galloway and Wissler, 1927 (Plate 1, Figures 12-16; Plate 12, Figures 2-3 and 7)

Specimens are frequent within the variability range of Globigerina bulloides, where the final chamber is reduced in size. Such smaller final chambers are as a rule delicate and transparent. The wall structure is identical to that in Globigerina bulloides where the final chamber is reduced in size. Such smaller final chambers are as a rule delicate and transparent. The wall structure is identical to that in Globigerina bulloides s.s. The wall of the final chamber may be covered by widely spaced plate shaped crystals, indicators for a beginning thickening of the wall (Plate 1, Figure 16; Plate 12, Figure 7). A preferential radial arrangement of these crystals in rows may serve as a strengthening of the newly formed wall. Plate 12, Figures 2-3 illustrate subsequent growth patterns of the wall surface, during which an increase of the pore radius takes place in the older chambers.

Globigerina bulloides cf. quadrilatera also differs from Globigerina bulloides bulloides in that the reduced final chamber no longer follows the normal coiling pattern but is tilted towards the umbilicus. In Globigerina quadrilatera s.s. the chambers are more closely appressed.

\section{Globigerina bulloides riveroae Bolli and Bermudez, 1965} (Plate 1, Figure 10)

1965 Globigerina riveroae - Bolli, H. M. and Bermudez, P. J., Asoc. Venez. Geol., Min. Petrol., Bol. Inf., 8, no. 5, p. 137, pl. 1, fig. 1-6.

Specimens assigned to this species differ from Globigerina bulloides bulloides in their large and wide aperture, umbilical in position with tendency to become extraumbilical. The final chamber is not hemispherical, as is typical for Globigerina bulloides s.s., but slightly appressed tangentially and thus shows sometimes a certain affinity to Globigerina bermudezi.

\section{Globigerina intermediate between G. bulloides bulloides and G. bulloides umbilicata (Plate 1, Figures 17-18)}

This form also possesses four chambers per whorl. The chambers are arranged in a slightly wider spire than in Globigerina bulloides 
bulloides but are similar to Globigerina diplostoma Reuss, a form originally described from the Middle Miocene of the Vienna Basin. Globigerina diplostoma is close to Globigerina praebulloides Blow.

Globigerina bulloides umbilicata Orr and Zaitzeff, 1971

(Plate 1, Figures 19-20 and 22-24; Plate 11, Figures 13)

1971 Globigerina umbilicata - Orr, W.N. and Zaitzeff, J.B., J. Foram. Res., 1, p. 18, pl. 1, fig. 1a-3c.

This form differs from Globigerina bulloides bulloides in the wider spiral arrangement of the chambers and an increase of from 4 to $4-1 / 2$ to 5 chambers per whorl. Such five-chambered specimens were referred to by Blow $(1969$, p. 317) as Globigerina bulloides concinna Reuss. However Globigerina concinna was described from the Middle Miocene of the Vienna Basin and is more related to Globigerina praebulloides. It has no phylogenetic relation to the Pliocene-Recent Globigerina bulloides umbilicata. Plate 1, Figure 24 illustrates that secondary apertures may be present on the spiral side.

Globigerina calida calida Parker, 1962

(Plate 3, Figure 1-8; Plate 12, Figures 9-12)

1959 Globigerina sp. - Bradshaw, J.S., Cushm. Found. Foram. Res., Contr., 10, p. 38, pl. 6, fig. 19, 26-28. 1962 Globigerina calida -

Parker, F.L., Micropaleont., 8 p. 221, pl. 1, fig. 9-13, 15. 1969

Globigerina calida calida Parker - W. H., Proc. 1st Int. Conf.

Plankt. Microfoss. p. 380, pl. 13, fig. 9-10.

The species was emended by Blow (1969) and is here treated accordingly. Shape of test low trochospiral with tendency to become planispiral; chambers globular, those of the last whorl becoming radially elongate; four to six chambers in the last whorl; aperture an asymmetrial arch, umbilicalextraumbilical in position, and surrounded by a wide asymmetrical lip. The wall is thick, regularly perforated; radius of pores is wider in earlier chambers. Chamber surface densely covered by massive spines which possess a circular to triangular cross section. The basal spine-cuffs merge in earlier chambers to high ridges and at the same time increase the wall thickness (Plate 12, Figure 10-12). The mode of coiling and the shape of spines point to a certain affinity with Globigerinella, e.g., Globigerinella siphonifera.

Occurrence: According to Blow, restricted to the ?Late Pleistocene-Holocene. In Site 147 from Core 1 to Core 8 (core-catcher) (near the base of Zone X of Ericson and Wollin).

Globigerina calida praecalida Blow, 1969

(Plate 3, Figure 9-13; Plate 13, Figure 2)

1969 Globigerina calida praecalida - Blow, W. H., Proc. 1st Int. Conf. Plankt. Microfoss., p. 380, pl. 13, fig. 6-7; pl. 14, fig. 3.

This form is the ancestor of Globigerina calida calida, from which it differs in the narrower umbilicus and in having chambers that increase more slowly in size, show no radial elongation and are more closely appressed. The subspecies was originally described as having four chambers in the last whorl, but here also includes forms with five chambers.

The coiling is very low trochospiral giving the test an almost planispiral Globigerinella siphonifera-like look, but with the aperture remaining in an interiomarginal umbilical-extraumbilical position. The aperture is similar to that in Globigerina calida calida. The wall is very thick with large pores.

Occurrence: Present in Site 147; predominant in the lower part of the section, to become largely replaced by Globigerina calida calida in the lower part of Zone X (Ericson and Wollin).

Range: Globorotalia dutertrei Zone to Holocene.

Globigerina clarkei Rögl and Bolli n. sp. (Plate 4, Figures 13-15)

1971 Globigerina aff. Globigerina quinqueloba Natland Brönnimann, P. and Resig, J., Init. Rept. DSDP, 7, p. 1300, pl. 43 , fig. $8-9$.

Holotype: Plate 4, Figure 14.

Dimensions: maximum diameter $0.135 \mathrm{~mm}$; minimum diameter $0.118 \mathrm{~mm}$; height of test $0.062 . \mathrm{cm}$.

Type locality: Cariaco Basin, Caribbean Sea: lat $10^{\circ} 42,48^{\prime} \mathrm{N}$; long $65^{\circ} 10,48^{\prime} \mathrm{W}$.
Type sample: Deep Sea Drilling Project, Leg 15, Site 147, Core 4 , core-catcher $(32.00 \mathrm{~m})$.

Type stratum: Late Pleistocene; Globorotalia truncatulinoides truncatulinoides Zone, Globigerina bermudezi Subzone; Zone Y after Ericson and Wollin.

Depository: Museum of Natural History, Basel, No. C-27173

Description: Shape of test very low trochospiral, axially compressed; equatorial periphery subcircular - elongate, slightly lobulate; axial periphery rounded. Ten subglobular axially compressed, tightly arranged chambers, five in the last whorl, final chamber slightly radially elongate. Sutures distinct, fairly incised, radial. Umbilicus small, shallow. Aperture a narrow slit, umbilical extraumbilical, with aperture flap. Wall very thick, almost smooth, only slightly transparent, with few but large and widely spaced pores, no spines visible.

Paratypes: Fifty specimens. Leg 15, Site 147, Core 4, corecatcher: NMB C-27171-72, 27226/1-24. Core 15, Section 2 (70-72 $\mathrm{cm})$ : NMB C-27226/25-48.

Dimensions (paratypes): Maximum diameter $0.103-0.132 \mathrm{~mm}$; average $0.117 \mathrm{~mm}$; minimum diameter $0.086-0.132 \mathrm{~mm}$, average $0.099 \mathrm{~mm}$.

Number of chambers (paratypes): 9-13, average 11.31.

The shape of test is intermediate between Globigerina quinqueloba and Turborotalita humilis, somewhat elongate, only slightly lobulate and axially compressed. Nine to thirteen chambers in two to two and a half whorls. Final chamber radially elongate. Aperture narrow, usually with an apertural flap, extending towards the umbilicus. In specimens with very thick walls the apertural slit may become almost completely closed (Plate 4, Figure 15). The wall is very thick; in more delicate specimens it may be covered by fine, spine-like rugosities, similar to the bases of spines in Globigerina quinqueloba.

Remarks: Until the origin of the new species is established it is placed in Globigerina with some reservation.

Differential diagnosis: The new species appears to be closest to Globigerina quinqueloba from which it differs in the smaller size, thickness of chamber wall and the more umbilicalextraumbilical position of the aperture. With largest diameter varying between 0.11 to $0.25 \mathrm{~mm}$ with an average of $0.19 \mathrm{~mm}$, and 11 to 18 chambers, average 13.3 chambers, Globigerina quinqueloba of Site 147, though small in size, is distinctly larger than the new species. According to Parker $(1962$, p. 225) G. quinqueloba reaches up to $0.27 \mathrm{~mm}$ in diameter. The test is also more compressed, the chambers less inflated and closer arranged in the new species, with shallower and less distinct intercameral sutures.

Turborotalita humilis which possesses a similarily compressed test of about equal size in Site 147 as Globigerina clarkei n.sp., always has six to seven chambers in the last whorl against five in the new species. Turborotalita humilis is further more circular in equatorial outline and the much narrower chambers are more closely attached. The last chamber is not bulla-like in Globigerina clarkei $\mathrm{n} . \mathrm{sp}$. as it is in T. humilis.

Occurrence: With some interruptions throughout Site 147, more frequent in the lower part of the section of Site 147. In Site 147, from Late Pleistocene to Holocene, Globorotalia truncatulinoides truncatulinoides Zone; after Brönnimann and Resig, 1971, from Middle Pliocene to Middle Pleistocene.

The species is named for Captain J.A. Clarke, master of the Glomar Challenger.

Globigerina cf. falconensis Blow, 1959

(Plate 2, Figure 20; Plate 13, Figure 1)

1962 Globigerina falconensis Blow - Parker, F. L., Micropaleont.,

8 , p. 224 , pl. 1 , fig. $14,16-19.1971$ Globigerina falconensis

Blow - Bé, A.W.H., Vilks, G. and Lott, L., Micropaleont., 17, pl.

1 , fig. 5 .

The arrangement of chambers is similar to that in Globigerina bulloides bulloides, but the aperture which possesses a broad symmetrical lip is more distinctly umbilical in position, and the periphery is distinctly more lobate in equatorial view. The final chamber is either distinctly larger and radially somewhat elongate or much smaller than the penultimate chamber. The thin wall possesses average sized and widely spaced pores and loosely spread delicate spines with circular cross section. The Recent lobate form evolves 
gradually from the Miocene form, which is more more compact (Blow, 1959) and has more closely appressed chambers.

Globigerina megastoma cariacoensis Rögl and Bolli n. ssp.

(Plate 2, Figures 1-10; Plate 12, Figures 5-6; text Figure 4a-c)

Holotype: Plate 2, Figure 2; text-Figure 4a-c.

Dimensions: Largest diameter $0.403 \mathrm{~mm}$; height of spira 0.404 $\mathrm{mm}$.

Type locality: Cariaco Basin, Caribbean Sea, lat $10^{\circ} 42,48^{\prime} \mathrm{N}$; long $65^{\circ} 10,48^{\prime} \mathrm{W}$

Type sample: Deep Sea Drilling Project, Leg 15, Site 147, Core 2 , Section 1 , top $(4.00 \mathrm{~m})$.

Type stratum: Holocene; Globorotalia truncatulinoides truncatulinoides Zone; Globorotalia fimbriata Subzone; Zone Z after Ericson and Wollin.

Depository: Museum of Natural History, Basel (NMB), No. C-26962.

Description: Shape of test high trochospiral; equatorial periphery fairly lobate; axial periphery rounded. Fifteen globular chambers, increasing regularly in size, loosely arranged in slightly over three whorls. Umbilicus fairly shallow and large, near quadrangular in outline. Aperture a wide and low arch without lip; apertures of earlier chambers are visible in the umbilicus. The wall is transparent and delicate, densely and regularly covered by large pores, and with not very frequent, fine spines, circular in cross section. Around the base of the spines are cuffs of small plate shaped crystals.

Paratypes: Sixty-three specimens (NMB C-26960-64, 26981-83, 26986-87, 27082-83, 27223/1-50); Leg 15, Site 147, Core 2, Section 1, top.

Dimensions (paratypes): Diameter $0.277-0.473 \mathrm{~mm}$; height of spira $0.239-0.567 \mathrm{~mm}$; average diameter $0.363 \mathrm{~mm}$; average height of spira $0.366 \mathrm{~mm}$.

Number of chambers (paratypes): 11-17; average 13.67.

The height of spire is variable but always distinctly greater than in Globigerina bulloides s.1. The chambers are arranged in a loose high spire of slightly over three whorls. The chambers are globular or somewhat elongate in the last whorl and the final chamber may be tilted over the umbilicus (Plate 2, Figure 6). The wall structure is uniform. The wall is fairly thin, possesses regularly arranged large pores with a diameter larger than in Globigerina bulloides. The cuffs of small crystalls surrounding the spines at their base are clearly separated from each other. Only rarely are they enlarged giving the surface a rough appearance (Plate 2, Figures 5-6).

Differential diagnosis: The subspecies differs from Globigerina megastoma megastoma Earland, 1934 (see lectotype description of Banner and Blow, 1960, p. 14) in the wider aperture without lip and the larger number of chambers, 13 to 14 against 11 . The relationship is shown in the similar high trochospiral arrangement of chambers and the similar shape of the ultimate chamber. It would appear that differing ecological conditions account for the morphologic differences between Globigerina megastoma cariacoensis and the antarctic Globigerina megastoma megastoma. The elongated shape of chambers in some specimens suggests a relation to Globigerina bermudezi, in which chambers, however, are arranged in a much lower spire and with an aperture having the tendency to be more extraumbilical in position.

Globigerina megastoma cariacoensis is readily distinguished from Globigerina bulloides s.l. The chambers are arranged in a much higher trochospire, are more loosely coiled, and increase less rapidly in size. Through this, the test becomes more circular in equatorial view and the umbilicus is distinctly wider. The aperture is much larger, but not so highly arched, and the wall is more delicate with distinctly larger pores.

Occurrence: Throughout Site 147, particularly frequent in Cores 1 through 8 (Zone $\mathrm{X}$ to $\mathrm{Z}$ of Ericson and Wollin). Late Pleistocene to Holocene.

\section{? Globigerina quinqueloba Natland, 1938}

$$
\text { (Plate 4, Figure 10-12) }
$$

1938 Globigerina quinqueloba - Natland, M.L., Scripps Inst. Oceanogr., Bull., Tech. Ser., 4, no. 5, p. 149, pl. 6, fig. 7. 1962 Globigerina quinqueloba Natland - Parker, F.L., Micropaleont.,
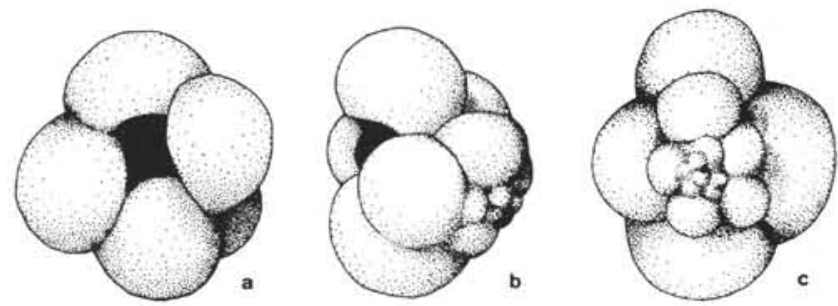

$0,5 \mathrm{~mm}$

Figure 4. Globigerina megastoma cariacoensis Rögl and Bolli, n. ssp. - DSDP, Leg. 15, Site 147, Core 2, Section 1 (top), Holocene.

8 , p. 225 , pl. 2, fig. 7-16. 1970 Globigerina quinqueloba egelida - Cifelli, R. and Smith, R.K., Smithson. Contr. Palaeobiol., 4, p. 32 , pl. 3, fig. 4-7.

Shape of test very low trochospiral; five chambers in the last whorl. Chambers subglobular, last chamber radially elongate and extending over the umbilicus. The umbilicus and the umbilicalextraumbilical aperture also may be partially covered by an apertural flap. Blow $(1969$, p. 373, no. 203) places the species in Turborotalita, which appears justified considering the shape of test and last chamber. However, living Globigerina quinqueloba possesses very thin, long and flexible spines (Hemleben, 1969, pl. 17, fig. 4), which are not preserved in specimens from the sediment. With the possession of spines, Globigerina quinqueloba belongs to family Globigerinidae and not to Globorotaliidae and Turborotalita. The position of Globigerina quinqueloba within the genus Globigerina looks questionable based on shape of test. The wall is thin, vitreous transparent, almost smooth, with few but large pores and only few and small bases of spines. The apertural flap is often missing in globular final chambers. Such specimens compare well with Globigerina quinqueloba egelida Cifelli \& Smith. However, no distinct morphologic or stratigraphic difference was observed between Globigerina quinqueloba s.s. and Globigerina quinqueloba egelida.

Globigerina rubescens Hofker, 1956

(Plate 4, Figure 6-9; Plate 13, Figure 3)

1956 Globigerina rubescens - Hofker, J., Copenhagen Univ. Zool.

Mus., Spolia, 15, p. 234, pl. 32, fig. 26, pl. 35, fig. 18-21.

Small, high trochospiral test, consisting of globular chambers, four in the last whorl. Aperture high arched with thick, symmetrical lip. Umbilicus shallow. Occasionally specimens have a secondary aperture on the spiral side between ultimate chamber and inner whorl (Plate 4, Figure 9). The wall is thick, rough, covered by a thin calcite crust which covers the honeycomb shaped pits containing the small pores. The delicate spines are circular in cross section. The characteristic orange red coloring is preserved only in the upper part of the section of Site 147 .

Globigerina sp. 1

(Plate 2, Figures 21-23; Plate 11, Figure 14)

This low trochospiral Globigerina is similar to Globigerina bulloides s.s. in its early stage. The apertural face of the final chamber appears compressed and contains an oblique umbilical, extraumbilical extended aperture. The wall structure is similar to that in Globigerina bulloides. Occasional specimens may possess a secondary spiral aperture in the last chamber. The form was found only in a few samples.

Globigerina sp. 2

(Plate 2, Figures 24-26; Plate 11, Figure 15)

1965 Globigerina bulloides d'Orb. - Cifelli, R., Smithson. Misc.

Coll., 148 , no. 4 , p. 11 , pl. 1 , fig. 5 .

The test of this scarce and stratigraphicaly restricted form possesses four chambers in the last whorl. The umbilicus is completely covered by a large bulla-like chamber, leaving a very 
small aperture only. One to two additional small bullae may occur in continuation of this large final chamber. The wall is very thin, transparent and possesses very delicate spines. It would appear that these forms belong to the Globigerina bulloides group, but possess aberrant bulla-like final chambers.

\section{Bulla like structures in some Globigerinas (Plate 11, Fig- ures 7-12)}

Bulla-like structures or strongly aberrant final chambers may occur occasionally in species of Globigerina. They are not to be confused with true bullae as in Globigerinita dissimilis, where the structure is distinct and present in a high number of specimens. Of the investigated species, only Globigerina sp. 2 (Plate 2, Figures 24-26) possesses bullae-like final chambers in most specimens.

\section{Genus GLOBIGERINOIDES Cushman, 1927}

As the subfamily definition but with the following restrictions: test trochospiral, primary aperture umbilical, with secondary sutural apertures on spiral side, one or more per chamber, often confined to the last few chambers.

\section{Globigerinoides conglobatus (Brady, 1879)} (Plate 4, Figure 22)

1879 Globigerina conglobata - Brady, H.B., Quart. J. Micr. Sci., London, n.s., 19, p.286. 1960 Globigerina conglobata Brady Banner, F.T. and Blow, W.H., Cushm. Found. Foram. Res., Contr., 11, p. 6, pl. 4, fig. 4 (lectotype).

This characteristic species is very poorly represented in the 147 section.

Globigerinoides ruber ruber (d'Orbigny, 1839)

(Plate 5, Figures 1-5 and 10; Plate 14, Figures 7-9)

1839 Globigerina rubra - d'Orbigny, A., in de la Sagra, Hist. Phys. Nat. Ile Cuba, p. 82-83, pl. 4, fig. 12-14. 1960 Globigerina rubra d'Orb. - Banner, F.T. and Blow, W.H., Cushm. Found. Foram. Res., Contr., 11, p. 19, pl. 3, fig. 8 (lectotype).

Test low to fairly distinct trochospiral, with three globular chambers per whorl. The average sized, low to semicircular apertures are symmetrical above the intercameral sutures of previous whorls. The late chambers possess two secondary apertures each. The sutures are distinctly and deeply incised. The chamber wall is thick and coarsely perforated. The increasing thickness of the wall and the development of pores in a single individual, from a delicate final chamber to earlier ones is shown on Plate 14, Figures 7-9. The spines, circular to triangular in cross section, are present in newly formed chambers, but mostly broken off in earlier ones. Thin secondary calcite crusts cover the spine remains, their bases, and the chamber wall. Calcite crests developing between spine bases form a honeycomb shaped surface. The red coloring, typical for this species, is preserved interspaced with layers containing primary white colored specimens down to Core 6 , Section 1 , top. Only scarce specimens are found down to Core 12, Section 4. The coloring becomes progressively weaker in the deeper part of the interval and remains particularly restricted to the early chambers.

\section{Globigerinoides ruber elongatus (d’Orbigny, 1826)}

(Plate 5, Figures 11-12; Plate 14, Figure 12)

1826 Globigerina elongata - d'Orbigny, A., Ann. Sci. Nat., ser. 1, 7, p. 277 , no. 4. 1960 Globigerina elongata d'Orb. - Banner, F.T. and Blow, W.H., Cushm. Found. Foram. Res., Contr., 11, p. 12, pl. 3, fig. 10 (lectotype).

Test medium to high trochospiral; chambers are not as globular and the distinct sutures less deeply incised compared with Globigerinoides ruber ruber. Apertures are semicircular and of average size. There is a single secondary aperture per chamber, in contrast to two in Globigerinoides ruber ruber. The wall is thick, very coarsely perforated and shows no red coloring. Globigerina cyclostoma Galloway and Wissler, 1927 from the Pleistocene of California is probably a synonym.

Globigerinoides ruber pyramidalis (Van den Broeck, 1876) (Plate 5, Figure 7-9; Plate 14, Figure 12)

1876 Globigerina bulloides d'Orb. var. rubra d'Orb. subvar. pyramidalis - Broeck, E., van den, Ann. Soc. Belg. Micr., 2 (1875-1876), p. 127, pl. 3, fig. 9-10.1961 Globigerinoides ruber var. pyramidalis (van den Broeck) - Bermudez, P.J., Mem. III. Congr. Geol. Venez., Bol. Geol., 3, p. 1235, pl. 11, fig. 2-3.

Shape of test high trochospiral; chambers globular with large, semicircular apertures; sutures distinct and deep. Like Globigerinoides ruber ruber, each chamber possesses two secondary spiral apertures. The subspecies differes from it in the height of spire, the more loosely arranged chambers and the larger apertures. The wall is similar in the two forms and also red coloring.

\section{Globigerinoides cf. ruber pyramidalis (Van den Broeck, 1876)} (Plate 5, Figure 6; Plate 14, Figure 10)

Small-sized specimens are included here with a chamber arrangement similar to Globigerinoides ruber pyramidalis, but with smaller chambers in a very tight and high spire. The wall structure is identical with that of juvenile Globigerinoides ruber ruber and Globigerinoides ruber pyramidalis.

\section{Globigerinoides suleki Bermudez, 1961 \\ (Plate 4, Figure 23; Plate 15, Figure 3)}

1961 Globigerinoides suleki - Bermudez, P.J., Mem. III. Congr. Geol. Venez., Bol. Geol., 3, p. 1241, pl. 10, fig. 9.

The average size, low trochospiral test consists of globular chambers, which increase rapidly in size, three to three and a half per whorl. Chambers are separated by deeply incised sutures. The umbilicus is very small and deep, therefore the umbilical aperture is only poorly visible. The wall is thin, with closely spaced, large pores, Delicate spines with circular cross section rest on bar-like bases. The species is not frequent in the section and restricted mainly to the warm-water cycles.

Globigerinoides tenellus Parker, 1958

(Plate 5, Figures 16-18; Plate 13, Figures 12)

1958 Globigerinoides tenellus - Parker, F.L., Swed. Deep-Sea Exped., Rept., 8, fasc. 2, no. 4, p. 280, pl. 6, fig. 7-11.

Shape of test low to high trochospiral. Wall thick, coarse, with small, widely spaced pores. Secondary calcite crusts cover the contours of the surface as in Globigerina rubescens (Plate 13, Figure 12). The bases of spines, circular in cross section, are distinct and fairly high. Typical is the high arched, umbilical aperture and the high spiral, secondary apertures (Plate 5, Figure 17). The species is intermittently present in the lower part of Site 147, where it may be common. It was not observed in its uppermost part.

\section{Globigerinoides trilobus sacculifer (Brady, 1877)}

(Plate 5, Figures 13-15, Figures 1-2)

1877 Globigerina sacculifera - Brady, H.B., Geol. Mag. London, n.s., dec. 2, 4, p. 535. 1884 Globigerina sacculifera - Brady, H.B., Rept. Voy. Chall., Zoll., 9, pt. 22, p. 604 , pl. 80, fig. $11-17$, pl. 82, fig. 4. 1957 Globigerinoides triloba sacculifera (Brady) - Bolli, H.M., U.S. Nat. Mus., Bull., 215, p. 113, pl. 25, fig. 5-6. 1960 Globigerina sacculifera Brady - Banner, F.T. and Blow, W.H., Cushm. Found. Foram. Res., Contr., 11, p. 21, pl. 4, fig. 1-2 (Lectotype and ideotype). 1970 Globigerinoides trilobus sacculifer (Brady) - Bolli, H.M., Init. Repts. DSDP, 4, p. 579 , pl. 1, fig. 5 .

The species compares in its variability with the ideotype and holotype of Banner and Blow (1960). All stages within the population are included in the species, including those with spherical, laterally compressed (Plate 5, Figures 13-15) or typically sack-like extended final chamber. 
Globigerinoides sp.

(Plate 5, Figure 19-20)

The spherical, low to medium trochospiral test possesses two and a half whorls of globular, closely arranged chambers, which are separated by distinct but only weakly incised sutures. The last whorl consists of three and a half to four chambers. The umbilicus is large and shallow. The primary aperture is wide, asymmetrical, low arched and extends toward the periphery. The secondary apertures are also wide, low arched and asymmetrical. The wall is thick with spine bases similar to those in Globigerinoides tenellus but with smaller pores.

\section{Genus ORBULINA d'Orbigny, 1839}

Orbulina universa d'Orbigny, 1839

(Plate 4, Figures 18-21; Plate 14, Figures 4-6)

1839 Orbulina universa - d'Orbigny, A., in de la Sagra, Hist. Phys. Nat. Ile Cuba, p. 3; pl. 1, fig. 1.1971 Orbulina universa d'Orb. Thiede, J., Meteor-Forsch. Erg., Reihe C., no. 7, p. 25, pl. 1, fig. $1-9$.

The question whether Orbulina universa should be treated as a single species has been discussed on several occasions, e.g., by Parker (1962). Considerable variability exists also in the Site 147 material. In addition to spherical forms of varying size, are present specimens of egg shape, somewhat pointed in the polar areas, or of globular but slightly polygonal shape, somewhat pointed in the polar areas, or of globular but slightly polygonal shape. Two- and threechambered forms occur which are here left in Orbulina, and are not included in Biorbulina, which is regarded as a synonym. The wall structure is similar to that of other genera of the family, in that it gradually thickens during ontogeny, during which an enlargement of pore size also takes place. The calcification of test is shown also by Thiede (1971). The tendency of the average size specimens to be smaller in cooler water is clearly illustrated in the Site 147 section, where in such intervals the specimens only reach a quarter or a third of their normal size in warm waters (Plate 4, Figure 21). Typical for these colder water small forms are the much increased wall thickness and the almost closed pores (Plate 14, Figure 6).

\section{Genus SPHAEROIDINELLA Cushman, 1927}

Sphaeroidinella dehiscens (Parker and Jones, 1865)

1865 Sphaeroidina bulloides d'Orb. var. dehiscens - Parker, W.K. and Jones, T.R., Roy. Soc. London, Phil. Trans., 155, p. 369, pl. 19, fig. 5a-b. 1960 Sphaeroidina bulloides d'Orb. var. dehiscens Parker and Jones - Banner, F.T. and Blow, W.H., Cushm.

Found. Foram. Res., Contr., 11, p. 35, pl. 7, fig. 3.

This species is extremely scarce in Site 147 where only a few specimens were found. The reason for this is probably the shallow Cariaco Basin sill, causing a partial isolation of the Basin from the open Caribbean Sea. Be' (1967) has noted that Sphaeroidinella dehiscens occurs only in water depth of over 500 meters.

\section{Genus CANDEINA d'Orbigny, 1839}

\section{Candeina nitida nitida d'Orbigny, 1839}

1839 Candeina nitida - d'Orbigny, A., in de 1 a Sagra, Hist. Phys. Nat. Ile Cuba, p. 107. 1969 Candeina nitida nitida d'Orb. Blow, W.H., Proc. 1st Int. Conf. Plankt. Microfoss., p. 335, pl. 23 , fig. $1-4$.

The species is present only in the core catcher of Core 1 .

\section{Subfamily HASTIGERININAE Bolli, Loeblich and Tappan, 1957}

As the family definition but with the following restrictions: test initially trochospiral later becoming streptospiral or planispiral. Chambers globular, ovate to clavate. Dependent on coiling, the aperture is umbilical, extraumbilical, spiroumbilical or equatorial. The spines are triangular or triradiate in cross section; circular cross sections are also found. The investigated genera are distinguished on the mode of coiling and not on the shape of spines.

\section{Genus GLOBIGERINELLA Cushman, 1927}

Synonym: Bolliella Banner and Blow, 1959.

Early portion of test low trochospiral becoming planispiral and biumbilicate involute to evolute. Aperture low arched, equatorial.
Chambers globular to radially extended. Wall evenly covered with spines, which may be circular or triradiate in cross section.

\section{Globigerinella siphonifera siphonifera (d'Orbigny, 1839)}

(Plate 3, Figures 14-15 and 19; Plate 13, Figure 4)

1839 Globigerina siphonifera - d'Orbigny, A., in de la Sagra, Hist. Phys. Nat. Ile Cuba, 8, p. 83, pl. 4, fig. 15-18. 1879 Globigerina aequilateralis - Brady, H.B., Quart. J. Micr. Sci., London, n.s., 19, p. 285. 1960 Hastigerina (Hastigerina) siphonifera (d'Orb.) Banner, F.T. and Blow, W.H., Micropaleont., 6, p. 22, fig. 2 (lectotype). 1962 Globigerinella siphonifera (d'Orb.) - Parker, F.L., Micropaleont., 8, p. 228, pl. 2, fig., 22-28. 1969 Globigerinella aequilateralis (Brady) - Bé, A.W.H., Proc. 1st Int. Conf. Plankt. Microfoss., p. 89, pl. 1-2.

Shape of test in the adult is a loosely coiled planispire, slightly compressed laterally. The early stage often distinctly trochospiral. Globular chambers increase gradually in size. Wall rough, regularly covered by pores and bases of spines. Large triradiate spines amongst numerous delicate ones with a circular cross section are present in particular in juvenile tests (Plate 3, Figures 14 and 19, Plate 13, Figure 4). The similarity between the species and Hastigerina pelagica is discussed by Bé (1969).

\section{Globigerinella siphonifera involuta (Cushman, 1917)}

(Plate 3, Figures 16-18; Plate 13, Figures 5)

1917 Globigerina aequilateralis Brady var. involuta - Cushman, J.A., U.S. Nat. Mus., Proc., 51, no. 2172, p. 662. 1921 Globigerina aequilateralis Brady var. involuta - Cushman, J.A., U.S. Nat. Mus., Bull., 4, no. 100, p. 293, fig. 11. 1961 Globigerinella involuta (Cushman) - Bermudez, P.J., Mem. III. Congr. Geol. Venez., Bol. Geol., 3, p. 1212, pl. 6, fig. 11, pl. 7, fig. 1. 1969 Hastigerina (Hastigerina) siphonifera involuta (Cushman) - Blow, W.H., Proc. 1st Int. Conf. Plankt. Microfoss., p. 375 , no. 208.

The subspecies is involute and tightly coiled, with chambers of the last whorl rapidly increasing in size and becoming distinctly broader. Aperture a very narrow equatorial arch. The structure of the chamber wall is comparable with that of Globigerinella siphonifera siphonifera. The distinction of this subspecies from the central form is questioned by many authors. It is present mainly in the lower part of the Site 147 section.

\section{Genus HASTIGERINA Thomson, 1876}

Coiling planispiral throughout, aperture equatorial, chambers subglobular to radially extended. Large triradiate spines concentrated mainly in the peripheral area.

\section{Hastigerina pelagica (d'Orbigny, 1839)}

(Plate 3, Figures 20-23; Plate 13, Figures 10-11)

1839 Nonionina pelagica - d'Orbigny, A., Voy. Amer. Merid., 5, pt. 5, p. 27, pl. 3, fig. 13-14. 1876 Hastigerina murrayi - Thomson, W., Roy. Soc., London, Proc., 24, p. 534, pl. 22-23. 1884 Hastigerina pelagica (d'Orb.) - Brady, H.B., Rept. Boy. Chall., Zool., 9, p. 613, pl. 83, fig. 1-4, 6 (not 7-8). 1960 Hastigerina (Hastigerina) pelagica (d'Orb.) - Banner, F.T. and Blow, W.H., Micropaleont., 6 p. 20 (neotype). 1969 Hastigerina pelagica (d'Orb.) - Bé, A.W.H., Proc. 1st Int. Conf. Plankt. Microfoss., p. 89 , pl. 3-4.

Test bi-umbilicate, involute and planispiral. Chambers subglobular, regularly increasing in size. In juvenile stage, aperture low arched, ranging from umbilicus to umbilicus. In gerontic specimens the last, strongly broadened chambers are slightly separated from the inner whorl, which results in a considerable increase in the aperture volume (Plate 3, Figure 22). The wall of younger chambers is delicate, transparent, completely smooth, with wide spaced pores. In gerontic chambers, the wall is thicker, with large and more closely arranged pores. The large, massive, triradiate spines are particularly present in the early chambers. They may pierce through chambers of the next younger whorl, to which they may give support during their forming process (see Hemleben, 1969, p. 96, pl. $6-8$ ). In the gerontic stage the long spines of the early chambers are often visible as short stumps penetrating the late chambers (Plate 13, Figure 11). 


\section{Genus HASTIGERINELLA Cushman, 1927}

Synonym: Beella Banner and Blow, 1960.

Coiling becomes streptospiral after a trochospiral initial stage. Chambers subglobular to radially extended, may become hornshaped. Aperture umbilical - extraumbilical to equatorial, may become spiroumbilical in the streptospiral stage. Wall covered with spines of trigonal or triradiate cross section.

Hastigerinella digitata (Brady, 1879)

(Plate 4, Figures 16-17; Plate 13, Figures 6-9)

1879 Globigerina digitata - Brady, H.B., Quart. J. Micr. Sci., London, n.s., 19, p. 286 (part). 1884 Globigerina digitata Brady, H.B., Rept. Voy. Chall., Zoll., 9, pl. 80, fig. 6-10 (not pl. 82, fig. 6-7). Non 1911 Hastigerina digitata - Rhumbler, L., Plankt. Exped., Erg., 3 (1), p. 202, pl. 37, fig. 9-10 (homonym, nom. nud.). 1957 Hastigerinella digitata (Brady) - Bolli, H.M., Loeblich, A.R., Jr. and Tappan, H., U.S. Nat. Mus., Bull., 215, p. 32, pl. 5, fig. 3 a-b. 1960 Globorotalia (Beella) digitata (Brady) - Banner, F.T. and Blow, W.H., Micropaleont., 6, p. 26, fig. 11 a-c. 1962 Globigerina digitata Brady - Parker, F.L., Micropaleont., 8, p. 222, pl. 1, fig. 20-25.

Early whorls trochospiral, becoming extremely streptospiral in the adult. Aperture umbilical - extraumbilical to spiroumbilical depending on stage of coiling, with distinct lip. Chambers subglobular in the juvenile, later becoming distinctly radial elongate and increasing rapidly in size. Chambers of the last whorl have tube-like extensions with rounded to conical ends. Wall thick, regularly covered by pores and with widely spaced, very delicate spines of triangular to triradiate cross section (Plate 13, Figures 7-9).

\section{Hastigerinella riedeli Rögl and Bolli, n.sp.}

(Plate 4, Figures 1-5; Plate 14, Figures 1-3; text Figure 5 a-b)

Holotype: Plate 4, Figure 2; Text Figure 5 a-b.

Dimensions: Largest diameter $0.172 \mathrm{~mm}$; height of spira 0.111 $\mathrm{mm}$.

Type locality: Cariaco Basin, Caribbean Sea, lat $10^{\circ} 42,48^{\prime} \mathrm{N}$; long $65^{\circ} 10,48^{\prime} \mathrm{W}$.

Type sample: Deep Sea Drilling Project, Leg 15, Site 147. Core 6 , core-catcher $(51.00 \mathrm{~m})$.

Type stratum: Late Pleistocene; Globorotalia truncatulinoides truncatulinoides Zone, Globigerina calida calida Subzone; Zone X after Ericson and Wollin.

Depository: Museum of Natural History, Basel (NMB), No. C-27164

Description: Test very small, low trochospiral to fairly streptospiral. Twelve subglobular chambers in slightly over two whorls. Chambers increase slowly and regularly in size, are attached to each other fairly loosely and separated by distinct, deeply incised sutures. Last chamber slightly tilted towards the umbilicus, which is small and shallow. The final chamber possesses a small, low arched, umbilical aperture with a narrow, raised lip. The wall is delicate, transparent, smooth and shiny, with very small, widely spaced pores. Clusters of triangular, strong spines are positioned at the peripheral ends of chambers. At their base, the spines are surrounded by small, irregular, conical cuffs formed by calcite crystals.

Paratypes: Sixty-four specimens. Leg 15, Site 147, Core 2, Section 1 (top): NMB C-27162, 27224/1-4; Core 3, Section $1(100-102 \mathrm{~cm})$ : NMB C-27224/5-6; Core 4 (core-catcher): NMB C-27224/7-12; Core 5, Section 2 (114-116 cm): NMB C-27224/13-17; Core 6 (core-cather): NMB C-27163, 27165, 27170, 27224/18-60.

Dimensions (paratypes): Diameter $0.088-0.182 \mathrm{~mm}$; height of spire $0.052-0.126 \mathrm{~mm}$; average diameter $0.141 \mathrm{~mm}$; average height of spire $0.084 \mathrm{~mm}$.

Number of chambers (paratypes): 10-17, average 12.16 .

The variability of the species is largely restricted to the test size and the number of chambers, which are arranged in two to two and a half, exceptionally, three whorls. High spired specimens are rare.

The five chambers of the last whorl are distinctly larger and are on a lower plane than those of the inner portion (Plate 4, Figures 3 and 5). This is caused by a streptospiral arrangement of chambers,
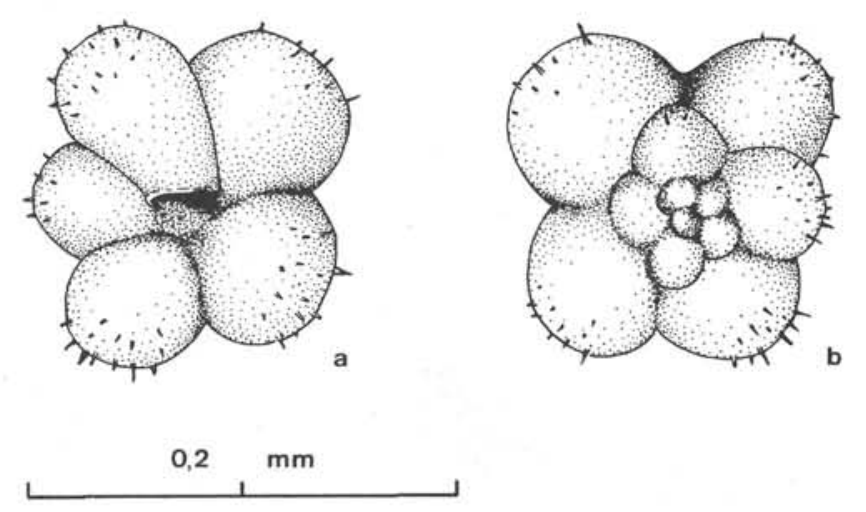

Figure 5. Hastigerinella riedeli Rögl and Bolli, n. sp. DSDP, Leg 15, Site 147, Core 6 (core catcher); Late Pleistocene.

which is also apparent in the position of the apertures (Plate 4, Figure 4; Plate 14, Figure 3).

Remarks: The species is placed in Hastigerinella because of its spine development and also because of the slight tendency to streptospiral coiling. The concentration of the spines at the distal ends of chambers is also typical for the genus. The new species is close to Hastigerinella rhumbleri Galloway, which has a similar arrangement of spines, but differs from it in the much smaller size. Hastigerinella rhumbleri is not present in Site 147. Occasionally specimens may have a reduced final chamber showing that the end of growth has been reached. The species differs from five chambered Globigerinas such as Globigerina quinqueloba in the robust triangular spines concentrated at the distal end of chambers and in the mode of coiling.

Distribution: The species is present throughout the section of Site 147 , from the Globorotalia hessi to the Globorotalia fimbriata Subzone of the Globorotalia truncatulinoides truncatulinoides Zone, Pleistocene to Holocene.

\section{Family GLOBOROTALIIDAE Cushman, 1927}

The definition of Parker (1962) is here adopted, following which the family is characterized by the absence of spines, the presence of which is typical for the Globigerinidae. Secondary knobs, pustules, crystallites and incrustations may cover the originally smooth wall surface. The test is trochospiral to streptospiral, chamber shape angular, oviform or globular. The perforated wall is smooth, rough or pitted.

\section{Genus GLOBOROTALIA Cushman, 1927}

Test low trochospiral, chambers subglobular to angular. A keel or imperforate band may be present along the periphery. Aperture umbilical - extraumbilical. Wall smooth with secondary thickening. Turborotalia is included in Globorotalia because presence or absence of a peripheral keel is regarded as of specific significance only.

Globorotalia bermudezi Rögl and Bolli n. sp.

(Plate 6, Figures 16-20; Plate 16, Figures 1-3; text Figure 6 a-c)

1971 Globorotalia (Turborotalia) sp. - Reiss, Z., Merling-Reiss, P. and Moshkovitz, S., Israel J. Earth-Sci., 20, p. 157, pl. 10, fig. $1-2$.

Holotype: Plate 6, Figure 17; Plate 16, Figures 2-3; text Figure 6 a-c.

Dimensions: Maximum diameter $0.237 \mathrm{~mm}$; minimum diameter $0.190 \mathrm{~mm}$; height of spira $0.083 \mathrm{~mm}$.

Type locality: Cariaco Trench, Caribbean Sea, lat $10^{\circ} 42,48^{\prime} \mathrm{N}$; long $65^{\circ} 10,48^{\prime} \mathrm{W}$.

Type sample: Deep Sea Drilling Project, Leg 15, Site 147, Core 2, Section 1, top $(4.00 \mathrm{~m})$.

Type stratum: Holocene; Globorotalia truncatulinoides truncatulinoides Zone; Globorotalia fimbriata Subzone; Zone Z after Ericson and Wollin.

Depository: Museum of Natural History, Basel (NMB), No. C-27087 

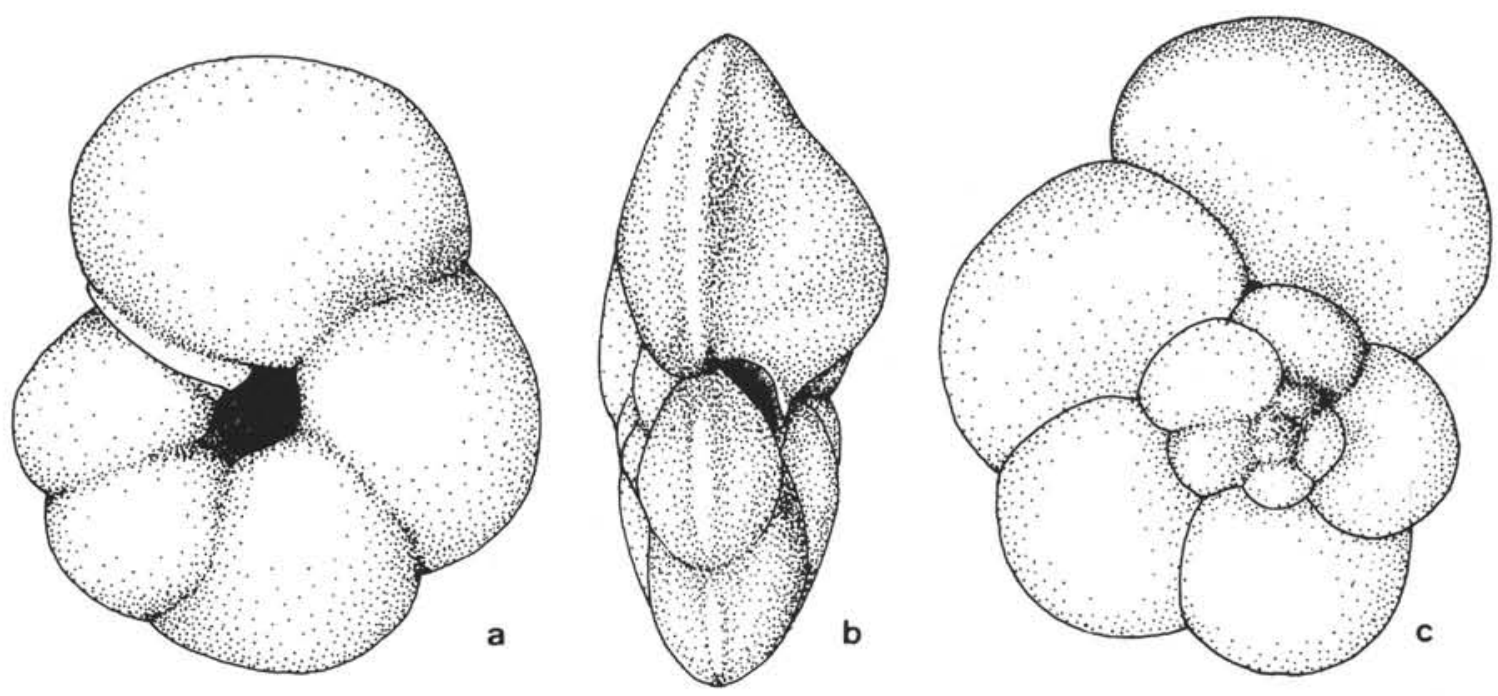

\title{
$0,2 \mathrm{~mm}$
}

\author{
L \\ Figure 6. Globorotalia bermudezi Rögl and Bolli, n. sp. - DSDP, Leg 15, Site 147, Core 2, Section 1, \\ (top); Holocene.
}

Description: Shape of test low trochospiral, axially strongly compressed, biconvex; equatorial periphery subcircular to slightly elongate, and lobulate; Axial periphery rounded, irregularly biconvex, slightly inflated spiral and more inflated umbilical side; peripheral margin without keel, but with a broad imperforate band. Twelve angled chambers in about two and a half whorls, five chambers in the last whorl. Chambers increase rapidly in size. Sutures distinct, fairly deep, slightly curved, somewhat more so on the spiral side. Umbilicus average sized, deep and open. Aperture a low umbilical - extraumbilical slit with a distinct lip. Wall very thin, transparent, smooth, with small, circular, but not very regularly distributed pores, which are more closely spaced on the umbilical than on the spiral side, where they are more frequent in the peripheral area (Plate 16, Figure 2). Very small and isolated knobs are present on the umbilical side (Plate 6, Figure 17; Plate 16, Figure 2, white spots).

Paratypes: Sixty-four specimens. Leg 15, Site 147, Core 2, Section 1 (top)(NMB C-27086, 27088-95, 27225/1-30); Core 4 (core-catcher)(27225/31-37); Core 11, Section $3(101-103 \mathrm{~cm})$ (27225/38-45); Core 18 (core-catcher)(27225/46-55).

Dimensions (paratype): Maximum diameter 0.162-0.294 mm; average $0.229 \mathrm{~mm}$; minimum diameter $0.132-0.254 \mathrm{~mm}$; average $0.191 \mathrm{~mm}$; height of spire $0.071-0.137 \mathrm{~mm}$; average $0.103 \mathrm{~mm}$.

Number of chambers (paratype): 10-16; average 12.81 .

The coiling mode is somewhat variable with the result that in axial view the spiral side can be slightly concave, plane or convex. The umbilical side is always distinctly convex.

Remarks: Globorotalia bermudezi n. sp. is apparently identical with the Globorotalia sp. described by Reiss et al. (1971) from the Mediterranean. A superficial similarity exists with Globorotalia scitula but the new species has a distinctly more open and deeper umbilicus. Furthermore, the chambers in Globorotalia bermudezi are higher on the umbilical side and more clearly separated. In Globorotalia scitula, the spiral intercameral sutures are much more curved and become almost tangential to the periphery. The wall of the new species is finer and more irregular perforated. Its average size is smaller and it also possesses smaller chambers.

Occurrence: Mostly common throughout Site 147, an indication that the new species lives closer to the surface than Globorotalia scitula which is rare. The new species is also present in the Pleistocene of the Caribbean Sites 148, 149, and 154A, and was reported by Reiss et al. (1971) from Mediterranean Late Pleistocene to Recent.
Range: Pleistocene to Recent, Globorotalia truncatulinoides trauncatulinoides Zone.

\section{Globorotalia cavernula Bë, 1967 \\ (Plate 7, Figures 5-6)}

1967 Globorotalia cavernula - Bé, A.W.H., Cushm. Found. Foram. Res., Contr., 18, p. 128, pl. 10, fig. 1-6. 1969 Globorotalia cavernula Bé and Boltovskoy, E., Micropaleont., 15, p. 252, pl. 2, fig. 13-14.

The sinistrally coiling test possesses a flat spiral and a high umbilical side. The equatorial periphery is only slightly lobate. Angle between spiral and umbilical side fairly acute. Last whorl with five chambers. Umbilicus characteristically wide and deep.

The species was originally described from the subantarctic Pacific and was later recognized by Boltovskoy from the transition zone of the Indian Ocean. Currents probably carried the species from the south into the Caribbean. Few specimens occur in Site 147 in the Samples Core 2, Section 1, top and Core 4, core-catcher, latest Pleistocene to Holocene.

Globorotalia crassaformis crassaformis (Galloway and Wissler, 1927) (Plate 7, Figures 7-14; Plate 16, Figures 7-8)

1927 Globigerina crassaformis - Galloway, J.J. and Wissler, St.G., J. Paleont., 1, p. 41, pl. 7, fig. 12 a-c. 1969 Globorotalia

(Turborotalia) crassaformis crassaformis (Galloway and Wissler)

- Blow, W.H., Proc. 1st Int. Conf. Plankt. Microfoss., p. 347, pl.

4 , fig. $1-3$, pl. 37 , fig. $1-4$.

Last whorl with four to five chambers. Spiral side flat, umbilical side high but somewhat variable. High-conical forms with acute periphery and four chambers are closest to the original description (Plate 7, Figures 7-10). A peripheral keel or imperforate band is usually present. Coiling is mostly sinistral. The wall is thin, often transparent, with few pustules, particularly on the umbilical side of earlier chambers (Plate 16, Figure 8). The pores are large, of irregular oval shape (Plate 16, Figure 7), more regularly distributed on umbilical than on spiral side.

\section{Globorotalia cultrata (d'Orbigny, 1839) (Plate 6, Figures 1-2)}

1839 Rotalina (Rotalina) cultrata - d'Orbigny, A., in de la Sagra, Hist. Phys. Nat. Ile Cuba, p. 76, 8, pl. 5, fig 7-9. 1960 Rotalina cultrata d'Orb. - Banner, F.T. and Blow, W.H., Cushm. Found., Foram. Res., Contr., 11, p. 34, pl. 6, Fig. 1 a-c (neotype). 1960 
Rotalina nitida Fornasini - Banner, F.T. and Blow, W.H., ibidem, p. 33, pl. 6, fig. 3 a-c (lectotype). 1969 Globorotalia (Globorotalia) cultrata (d'Orb.) - Blow, W.H., Proc. 1st Int. Conf. Plankt. Microfoss., p. 358, no. 168, pl. 6, fig. 4-8.

This species is restricted in the section of Site 147 to the Globigerina bermudezi to Globorotalia fimbriata Subzone.

\section{Globotalia fimbriata (Brady, 1884)}

1884 Pulvinulina menardii (d'Orb.) var. fimbriata - Brady, H.B., Rept. Voy. Chall., Zool., 9, pt. 22, p. 691, pl. 103, fig. 3 a-b. 1960 Pulvinulina menardii (d'Orb.) var. fimbriata - Banner, F.T. and Blow, W.H., Cushm. Found. Foarm. Res., Contr., 11, p. 25, pl. 5, fig. 2 a-b (lectotype). 1969 Globorotalia (Globorotalia) fimbriata (Brady) - Blow, W.H., Proc. 1st Int. Conf. Plankt. Microfoss., p. 362 , pl. 42 , fig. 6.

The species differs from Globorotalia cultrata in the spine-like knobs along the peripheral keel. Present only in the Holocene of Site 147.

\section{Globorotalia hirsuta (d'Orbigny, 1839)}

1839 Rotalina hirsuta - d'Orbigny, A., in Barker-Webb, P. and Berthelot, S., Hist. Nat. Iles Canaries, 2 (2), p. 131, pl. 1, fig. 37-39. 1969 Globorotalia (Globorotalia) hirsuta hirsuta (d'Orb.)

- Blow, W.H., Proc. 1st Int. Conf. Plankt. Microfoss., p. 398, pl. 8 , fig. $1-3$, pl. 43 , fig. $1-2$ (neotype).

Only a few specimens of the species are present, which, according to Bé and Tolderlund (1971), is confined mainly to the deeper waters of the subtropical region.

Globorotalia inflata (d'Orbigny, 1839)

(Plate 7, Figures 15-22; Plate 16, Figure 6)

1839 Globigerina inflata - d'Orbigny, A., in Barker-Webb, P. and Berthelot, S., Hist. Nat. Iles Canaries, 2 (2), p. 134, pl. 2, fig. 7-9. 1967 Globorotalia (Turborotalia) inflata (d'Orb.) - Banner, F.T. and Blow, W.H., Micropaleont., 13, p. 144, pl. 4, fig. 1 a-c, 11 (neotype). 1971 Globorotalia inflata (d'Orb.) - Thiede, J., Meteor Forsch.-Ergeb., Reihe C., 7, p. 41, pl. 8, fig. 8-12, pl. 9, fig. 1-2.

This species is characteristic for temperate to cooler water masses of the oceans. The form occurs commonly in Site 147 only in intervals indicative for cooler water, but is not restricted to those. Globorotalia inflata and the Globorotalia menardii - group practically exclude each other.

\section{Globorotalia menardii (Parker, Jones and Brady, 1865)}

(Plate 6, Figures 3-4)

1826 Rotalia (Rotalia) menardii - d'Orbigny, A., Ann. Sci. Nat., Paris, ser. 1,7 , p. 273 , no. 26 (nom. nudum). 1865 Rotalia menardii - Parker, W.K., Jones, T.R. and Brady, H.B., Ann. Mag. Nat. Hist., London, 16, ser. 3, p. 20, pl. 3, fig. 81.1960 Rotalia menardii Parker, Jones and Brady - Banner, F.T. and Blow, W.H., Cushm. Found. Foarm. Res., Contr., 11, p. 31, pl. 6, fig. 2 a-c (lectotype). 1969 Globorotalia (Globorotalia cultrata menardii (Parker, Jones and Brady) - Blow, W.H., Proc. 1st Int.

Conf. Plankt. Microfoss., p. 359, no. 171, pl. 6, fig. 9-11.

The species is restricted in Site 147 to the lower part of the section down from Core 6 , Section $4(28-30 \mathrm{~cm}$ to near the bottom).

Globorotalia scitula scitula (Brady, 1882)

(Plate 6, Figures 13-15; Plate 16, Figure 5)

1882 Pulvinulina scitula - Brady, H.B., Roy. Soc. Edinburgh, Proc., 11, 1880-1882, no. 111, p. 716. 1960 Pulvinulina scitula Brady - Banner, F.T. and Blow, W.H., Cushm. Found. Foram. Res., Contr., 11, p. 27, pl. 5, fig. 5 a-c (lectotype). 1971 Globorotalia (Turborotalia) scitula scitula (Brady) - Reiss, Z., Merling-Reiss, P. and Moshkovitz, S., Israel J. Earth-Sci., 20, p. 157, pl. 9, fig. 4-6.

The low biconvex test consists of about fourteen chambers with four to five in the last whorl. The intercameral sutures are strongly curved on the spiral but radial to only slightly curved on the umbilical side. The umbilicus is small, almost closed. Rare in Site 147.
Globorotalia truncatulinoides truncatulinoides (d'Orbigny, 1839) (Plate 6, Figures 8 and 12)

1839 Rotalina truncatulinoides - d'Orbigny, A., in Barker-Webb, P. and Berthelot, S., Hist. Nat. Iles Canaries, 2 (2), p. 132, pl. 2, fig. 25-27. 1969 Globorotalia (Globorotalia) truncatulinoides truncatulinoides (d’Orb.) - Blow, W.H., Proc. 1st Int. Conf. Plankt. Microfoss., p. 403 , pl. 5, fig. 10-12, pl. 49, fig 6 (neotype). 1969 Globorotalia (Globorotalia) truncatulinoides pachytheca Blow, W.H., ibidem, p. 405 , pl. 5, fig. 13-15, pl. 48, fig. 1-5.

The specimens present in the Site 147 section are mostly thin walled, but transitional forms to the thicker walled Globorotalia truncatulinoides pachytheca, separated by Blow, occur. The species is not common in the section and its coiling direction is generally random.

\section{Globorotalia tumida tumida (Brady, 1877) (Plate 6, Figures 10-11)}

1877 Pulvinulina menardii (d'Orb.) var. tumida - Brady, H.B., Geol. Mag., n.s., dec. 2, 4, p. 535. 1884 Pulvinulina tumida Brady Brady, H.B., Rept. Voy. Chall., Zool., 9, pt. 22, pl. 103, fig. 4-6. 1960 Pulvinulina menardii (d'Orb.) var. tumida Brady - Banner, F.T. and Blow, W.H., Cushm. Found. Foram. Res., Contr., 11, p. 26 , pl. 5, fig. 1 a-c (lectotype).

The species is common in the warmer parts of Site 147.

\section{Globorotalia tumida flexuosa (Koch, 1923) (Plate 6, Figure 9)}

1923 Pulvinulina tumida Brady var. flexuosa - Koch, R., Ecl. Geol. Helv., 18, p. 357 , fig. 9 a - 10 b. 1961 Globorotalia menardii flexuosa (Koch) - Ericson, D.B., Ewing, M., Wollin, G. and Heezen, C., Geol. Soc. Amer., Bull., 72, p. 260, pl. 3. 1967 Globorotalia tumida (Brady) - Parker, F.L., Bull. Amer. Paleont., 52, p. 182 , pl. 32 , fig. 7 (only). 1970 Globorotalia tumida flexuosa (Koch) - Bolli, H.M., Init. Rept. DSDP, 4, p. 583, pl. 6, fig. 7-12.

The subspecies has a wide distribution in the tropical Pleistocene and disappears suddenly in the Atlantic and Caribbean at the end of the warm interstadial of the Wisconsin (Zone X or flexuosa-Zone). It is found in Site 147 down from Core 6, Section 1, top to near the bottom in the warm intervals.

\section{Globorotalia ungulata Bermudez, 1960 (Plate 6, Figures 5-7)}

1960 Globorotalia ungulata-Bermudez, P.J., Mem. III. Congr. Geol. Venez., Bol. Geol., 3 p. 1304, pl. 15, fig. 6 a-b. 1969 Globorotalia (Globorotalia) ungulata Bermudez-Blow, W.H., Proc. 1st Int. Conf. Plankt. Microfoss., p. 372, pl. 8, fig. 13-15. Test shape is similar to that of Globorotalia tumida. Characterized by a very high umbilical side and oval equatorial outline. Characteristic is the angular apertural face, almost perpendicular to the spiral side of the chamber. The wall is thin compared with Globorotalia tumida, with only the earlier chambers sometimes possessing some small secondary pustule-like calcite deposits. The species was originally described from the Recent. In Site 147 , it is not common and is restricted to the Globigerina calida calida to Globorotalia fimbriata Subzone. Blow (1969) gives its range as from within Pliocene to Holocene. Further data on the distribution of Globorotalia ungulata may well show that the species is restricted to the latest Pleistocene and Holocene.

\section{Globorotalia sp.}

(Plate 7, Figures 1-4; Plate 16, Figure 4)

Included here are fairly frequent, sinistrally coiling specimens of average size, axially compressed and biconvex; two and a half to three whorls with five chambers in the last whorl. Equatorial periphery subcircular and slightly lobate. Peripheral margin in axial view rounded with a broad nonperforated band in the earlier chambers (Plate 7, Figure 3), the periphery of the last chamber possesses pores. Wall delicate, transparent and coarsely perforated. Coiling direction and shape of pores (Plate 16, Figure 4) are similar to Globorotalia crassaformis, from which however it differs by a higher spiral and less inflated umbilical side. Equatorial and axial profiles are similar to Globorotalia scitula. 


\section{Genus GLOBOROTALOIDES Bolli, 1957}

This genus differs from Turborotalita in the pitted wall structure and from Neogloboquadrina in the bulla-like shape of the final chamber.

\section{Globorotaloides hexagonus (Natland, 1938)}

1938 Globigerina hexagona-Natland, M. L., Scripps Inst. Oceanogr., Bull., 4, no. 5, p. 149, pl. 7, fig. 1 a-c. 1962 Globoquadrina hexagona (Natland)-Parker, F. L., Micropaleont., 8, p. 244, pl. 8, fig. 5-13. 1969 Globorotaloides hexagona hexagona (Natland)-Blow, W. H., Proc. 1st Int. Conf. Plankt. Microfoss., p. 373. 1970 Globorotalia subcretacea (Lomnicki)-Bolli, H. M., Init. Rept. DSDP, 4, p. 582, pl. 8, fig. 16-18. 1971 Globorotaloides hexagona Natland-Cita, M. B., Rev. Micropaleont., 14 (5), p. 37.

The species is present in Site 147 sporadically from bottom to Core 8, Section $3(127-129 \mathrm{~cm})$, Globigerina calida calida Subzone, Zone $\mathrm{X}$ of Ericson and Wollin. It disappears in the AtlanticCaribbean province within the Late Pleistocene, but continues to the Recent in the Indo-Pacific (Ericson et al., 1961; Blow, 1969; Cita, 1971).

\section{Genus NEOGLOBOQUADRINA Bandy, Frerichs \& Vincent, 1967}

Test mostly low trochospiral, chambers subglobular, without peripheral keel. Aperture umbilical-extraumbilical, during the early part of ontogeny at least, may become umbilical in the adult and may possess a tooth-like lip. Wall originally smooth, without spines, later thickened and pitted through secondary calcite deposits.

It is assumed that the genus develops from Globorotalia from which it differs in the pitted wall surface and the often umbilical position of the aperture in the adult. Neogloboquadrina differs from Globoquadrina in the position of the aperture which is always umbilical in the latter. Globoquadrina also differs in the straight apertural face and in the presence of an apertural tooth which only occasionally occurs in Neogloboquadrina. The genus differs from Globigerina in the structure of the aperture and in the absence of spines.

Neogloboquadrina dutertrei dutertrei (d'Orbigny, 1839)

Plate 9, Figures 1-9; Plate 10, Figures 1-10; Plate 17, Figures 1-6

1839 Globigerina dutertrei-d'Orbigny A., in de la Sagra, Hist. Phys.

Nat. Ile Cuba, p. 84, 8, pl. 4, fig. 19-21. 1960 Globigerina

dutertrei d'Orb.-Banner, F. T. and Blow, W. H., Cushm. Found.

Foram. Res., Contr., 11, p. 11, pl. 2, fig. 1 a-c (lectotype). 1967

Neogloboquadrina dutertrei dutertrei (d'Orb.)-Bandy, O. L.,

Frerichs, W. E. and Vincent, E., Cushm. Found. Foram. Res.,

Contr., 18, p. 152, pl. 14, fig. 3, 6-12. 1967 Neogloboquadrina

dutertrei subcretacea (Lomnicki)-Bandy et al., ibidem, pl. 14,

fig. 4-5. 1965 Globigerina dutertrei d'Orb.-Cifelli, R., Smith.

Misc. Coll., 148, no. 4 , p. 12 , pl. 2, fig. 1-2. 1970 Globigerina

dutertrei d'Orb.-Cifelli, R. and Smith, R. K., Smith. Contr.

Paleobiol., 4, p. 21 , pl. 2, fig. 1-2, text-fig. 13 .

This large-sized species possesses four to six chambers in the last whorl, is usually low but may also be fairly high trochospiral. The aperture in the juvenile stage is umbilical-extraumbilical in position with distinct tooth (Plate 9, Figures 1-2 and 4). During ontogeny, the position of the aperture moves to umbilical, occasionally still with a tendency towards an extraumbilical position. In the adult, apertural teeth are often absent. They are present mainly in specimens of warm-water areas and may therefore be controlled by ecology (Bandy et al., 1967; Zobel, 1968). Specimens with apertural teeth are rare in Site 147.

Very large specimens with many chambers, such as are typical for Neogloboquadrina dutertrei eggeri (Brady) are absent. Specimens with six chambers in the last whorl are here placed within Neogloboquadrina dutertrei dutertrei. Juvenile stages of the five to six chambered adult forms often consist of four chambers only per whorl. A subspecific differentiation of the four chambered adult forms (Plate 9, Figures 8-9) does not therefore seem justified.

The wall is primarily thin, transparent and smooth. As a first stage the wall becomes strengthened by narrow, rib-like calcite deposits which finally unite between pores and form the well known pitted surface (Plate 17, Figures 1-3). Additional calcite deposits result in a further thickening of the wall, resulting in the pore diameters becoming reduced and the surface having a "sugar grain" texture (Plate 17, Figures 4-6).

As typical for the Pleistocene and Recent forms of the species, the direction of coiling is almost exclusively dextral. The species is present in varying frequences throughout Site 147.

Neogloboquadrina dutertrei blowi Rögl and Bolli, nom. nov. (Plate 9, Figures 19-22; Plate 17, Figure 12)

1884 Globigerina (cretacea d'Orb.?)-Brady, H. B., Rept. Voy. Chall., Zool., 9, p. 596, pl. 82, fig. 10. Non 1900 Globigerina (cretacea d'Orb.?)-Lomnicki, J. R., Kosmos, Lemberg, 1899, 24 (4-5), pl. 1, fig. 2. Non 1901 Globigerina subcretacea-Chapman, F. J., Linn. Soc. London, Zool., 28, no. 184 , p. 410 , pl. 36, fig. 16 (homonym). 1968 Globigerina dutertrei Orbigny 1839 forma C-Zobel, B., Geol. Jb., 85, p. 111, Abb. 3. 1969 Globorotalia (Turborotalia) Subcretacea (Lomnicki)-Blow, W. H., Proc. 1st Int. Conf. Plankt, Microfoss., p. 392, pl. 4, fig. 18-20 (lectotype of Globigerina (cretacea d'Orb.?) Brady, 1884). Nomen novum introduced for Globigerina subcretacea Chapman, 1902.

The large test is low trochospiral with five chambers in the last whorl. The arched aperture is of average height and remains umbilical-extraumbilical in position throughout ontogeny. The wall is similar to Neogloboquadrina dutertrei dutertrei, usually with thick incrustations and a fine crystalline surface (Plate 17, Figure 12). The species differs from $N$. dutertrei dutertrei in that the aperture remains umbilical-extraumbilical, and from Neogloboquadrina dutertrei pseudopima in the increased number of chambers in the last whorl and in the wider umbilicus.

Taxonomic remarks: Globigerina subcretacea was described by Lomnicki from the Miocene of Wielicka, Poland, and compared by him with Globigerina (cretacea d'Orb.?) of Brady, 1884. This comparison was based on the similarity of coiling between the Miocene form and the Recent one figured by Brady. Examination of material from Wieliczka, kindly made available by Mrs. E. Luczkowska, Krakow, has shown that the Miocene Globigerina subcretacea Lonicki is a true spinose Globigerina with an umbilical-extraumbilical aperture. It is likely that the species evolved from the Miocene Globigerina concinna Reuss.

Blow (1969) selected a lectotype for Globigerina subcretacea Lomnicki from the Globigerina (cretacea d'Orb.?) Brady material, without having seen specimens from the Miocene type locality. Because the synonymy proposed by Lomnicki with the Recent form of Brady is erroneous, Blow's lectotype is also not valid.

Only the Recent Globigerina subcretacea described by Chapman, 1902, where Brady's form is also cited in the synonymy list, compares with the lectotype of Blow. As a homonym it is, however, invalid. Neogloboquadrina dutertrei blowi nom. nov. is therefore introduced here.

Occurrence: According to Blow from Late Pliocene to Recent. With some interruptions present through Site 147.

\section{Neogloboquadrina dutertrei pseudopima (Blow, 1969)}

(Plate 9, Figures 13-18; Plate 17, Figures 7-9)

1969 Globorotalia (Turborotalia) acostaensis pseudopima-Blow, W. H., Proc. 1st Int. Conf. Plankt. Microfoss., p. 387, pl. 35, fig. 1-7. 1970 Globorotalia dutertrei pseudopima Blow-Bolli, H. M., Init. Rept. DSDP, 4, p. 580 , pl. 2, fig. 7-9.

This four chambered species is flattened on the spiral side, tightly coiled and possesses an umbilical-extraumbilical aperture throughout. Characteristic and particularly typical in specimens from the lower part of the section is the very small umbilicus. The wall is strongly thickened, coarse and pitted.

\section{Neogloboquadrina dutertrei ssp.}

(Plate 9, Figures 10-12; Plate 17, Figures 10-11)

In some samples of Site 147, there were observed specimens of the dutertrei group with bullae. It is a four chambered, fairly high trochospiral form, tightly coiled, with a near smooth surface. The pits are covered by a thin calcite crust (Plate 17, Figures 10-11). Some specimens possess a bulla-like final chamber, covering the umbilicus. 
Neogloboquadrina pachyderma pachyderma (Ehrenberg, 1861) (Plate 11, Figures 2-6; Plate 16, Figure 12)

1861 Aristospira pachyderma-Ehrenberg, C. G., K. Akad. Wiss. Berlin, Monatsber., p. 276, 277, 303. 1873 Aristospira pachyderma-Ehrenberg, C. G., K. Akad. Wiss. Berlin, Abh. (1872), pl. 1, Fig. 4. 1881 Globigerina bulloides d'Orb. var. borealis-Brady, H. B., Ann. Mag. Natur. Hist., ser. 5, 8, no. 48, p. 412. 1960 Globigerina pachyderma (Ehrenberg)-Bé, A. W. H., Cushm. Found. Foram. Res., Contr., 11, p. 66 , text-fig. 1. 1969 Globigerina pachyderma (Ehrenberg) forma typica-Boltovskoy, E., Micropaleont., 15, p. 248, pl. 1, fig. 11 a-c.

This species is placed in Neogloboquadrina for the wall structure and apertural position. The wall possesses no spines (Bé, 1969; Bé and Tolderlund, 1971). The aperture is umbilical-extraumbilical in the juvenile stage and may become almost umbilical in the adult. The wall is strongly thickened by secondary calcite incrustations. The surface has a pitted, "sugar grain" like texture (Plate 16, Figure 12). Differences exist between arctic and antarctic populations (Kennett, 1968, 1970). The specimens of Site 147 compare with the arctic forms.

\section{Neogloboquadrina pachyderma incompta (Cifelli, 1961)}

(Plate 10, Figures 11-22; Plate 16, Figures 10-11)

1961 Globigerina incompta-Cifelli, R., Cushm. Found. Foram. Res., Contr., 12, p. 83, pl. 4, fig. 1-7 (non fig. 2). 1965 Globigerina pachyderma incompta Cifelli-Cifelli, R., Smithson. Misc. Coll., 148, no. 4, p. 11, pl. 1, fig. 4-6. 1969 Globigerina pachyderma (Ehrenberg) forma superficiaria-Boltovskoy, E., Micropaleont., 15, p. 248, pl. 1, fig. 12 a-b, pl. 2, fig. 1.1970 Globigerina incompta Cifelli-Cifelli, R. and Smith, R. K., Smithson. Contr. Paleobiol., 4, p. 26, fig. 3, text-fig. 14.

The subspecies is close to Neogloboquadrina pachyderma pachyderma but differs in the test being larger, with four and a half to five more loosely coiled chambers in the last whorl. The wall is deeply pitted but not as thickly calcified as in $N$. pachyderma pachyderma. The main distribution of Recent forms is from close to the surface down to 500 meters. Boltovskoy, for this reason, distinguished this form as forma superficiaria. Small and thick walled specimens, comparable to $N$. pachyderma pachyderma are predominant between 500 and 2000 meters. The subspecies is restricted to subpolar and temperate areas.

The subspecies is closely connected also with the dutertrei group as is shown by the similarity of the juvenile stages (Cifelli and Smith, 1970). Variability in test size and height of spire are considerable in Site 147 specimens. However, adult specimens never reach the size of the Neogloboquadrina dutertrei group. Dextrally coiling specimens are predominant.

\section{Genus TURBOROTALITA Blow and Banner, 1962}

The genus differs from Globorotalia in the presence of a bulla or of umbilical modifications in the final chamber.

\section{Turborotalita anfracta (Parker, 1967)}

(Plate 8, Figures 1-7; Plate 15, Figure 10)

1967 Globorotalia anfracta-Parker, F. L., Bull. Amer. Paleont., 52, p. 175 , pl. 28 , fig. 3-8. 1971 Globorotalia (Turborotalia) anfracta Parker-Brönnimann, P. \& Resig, J., Init. Rept. DSDP, 7, pt. 2, pl. 43 , fig. $2-3,6$; pl. 47 , fig. 2 , pl. 48 , fig. 4 .

The very low trochospiral test possesses four to five and a half chambers in the last whorl and is broadly rounded at the periphery. Spiral side fairly concave. The inflated chambers of the last whorl are oblique to the coiling axis which results in a lobulate periphery. The modified final chamber is inflated on the umbilical side and possesses a large apertural flap covering the aperture. Wall smooth, delicate, transparent and finely perforate.

Occurrence: With some interruptions throughout Site 147. According to Parker the species occurs from Late Pliocene.

Turborotalita iota (Parker, 1962)

(Plate 8, Figures 17-23; Plate 16, Figure 9)

1962 Globigerinita iota-Parker, F. L., Micropaleont., 8, p. 250, pl. 10, fig. 26-30. 1971 Turborotalita iota (Parker)-Bronnimann, P. and Resig, J., Init. Rept. DSDP, 7, pt. 2, p. 1324, pl. 23, fig. 6-8. Test low trochospiral, four and a half to five chambers in the last whorl; the somewhat elongate final chamber extends and becomes narrower towards the umbilicus. The umbilicus is of ten covered by a small bulla which may extend along the intercameral sutures, possessing there infralaminal apertures. Wall thin, transparent, smooth, turning whitish in large specimens with secondary incrustations (Plate 8, Figures 21-23; Plate 16, Figure 9). The species is frequent in many parts of Site 147. Following Parker, it is frequent in the South Pacific down to $50^{\circ} \mathrm{S}$, absent in the arctic region.

\section{Turborotalita humilis (Brady, 1884)}

1884 Truncatulina humilis - Brady, H.B., Rept. Boy. Chall., Zool., 9, pt. 22 , p. 665 , pl. 94, fig. 7 a-c. 1960 Truncatulina humilis Brady - Banner, F.T. and Blow, W.H., Cushm. Found. Foram. Res., Contr., 11, p. 36, pl. 8, fig. 1 a-c (lectotype). 1962 Globigerinita humilis (Brady) - Parker, F.L., Micropaleont., 8, p. 249 , pl. 10, fig. 1-25. 1962 Turborotalita humilis (Brady) Blow, W.H. and Banner, F.T., in Eames, Banner, Blow and Clarke, Fundam. Mid-Tertiary Strat. Correl., p. 122.

Typical forms were found in only a few samples from Site 147.

$$
\text { Turborotalita sp. }
$$

(Plate 8, Figures 8-14; Plate 15, Figures 11-12)

A small- to medium-sized sinistrally coiling form with a modified final chamber occurs in the higher part of Site 147, down to Core 8, Section 1, top. The low trochospiral test is formed by ten to eleven subglobular chambers with four to five chambers in the last whorl. Wall thin, transparent and smooth in small sized specimens; may be thick and covered by small calcite crystals in larger ones (Plate 15, Figure 12), but is never pitted as in the genus Neogloboquadrina. Pore size and distribution are similar to Turborotalita anfracta. The final chamber extends toward the umbilicus and possesses a large apertural flap which covers the aperture and partically also the umbilicus. In some specimens the final chamber may spread bulla-like partially across the umbilicus (Plate 8, Figure 11). Parker (personal communication) indicates that the form may be related to the dutertrei - group from which it differs, however, in the direction of coiling and in the nonpitted wall texture.

\section{Genus GLOBIGERINITA Brönnimann, 1951}

Test fairly high trochospiral, chambers subglobular, wall smooth or with secondary incrustations of small crystallites, without spines, Aperture umbilical, bullae with infralaminal apertures are possible.

Globigerinita glutinata (Egger, 1895)

(Plate 5, Figures 21-23; Plate 15, Figures 4-5)

1895 Globigerina gultinata - Egger, J.G., Bayer. Akad. Wiss., Abh., 182 Abt. (1893), p. 371, pl. 13, fig. 19-21. 1951 Globigerinita naparimaensis - Brönnimann, P., Cushm. Found. Foarm. Res., Contr., 2, p. 16, 17, pl. 1-14. 1957 Tinophodella ambitacrena Loeblich, A.R. and Tappan, H., Wash. Acad. Sci., J., 47 (4), p. 114, fig. la-3c. 1962 Globigerinita glutinata (Egger) - Parker, F.L., Micropaleont., 8, p. 246, pl. 9, fig. 1-16.

The final chamber possesses a narrow, slit-like, umbilical aperture with distinct symmetrical lip, which eventually becomes covered by a bulla. The wall is delicate, transparent and finely perforate. Secondary incrustations may be present in the shape of coarse crystalline pustules (Plate 15, Figure 4-5).

\section{Globigerinita uvula uvula (Ehrenberg, 1861)}

(Plate 5, Figure 24; Plate 15, Figure 7)

1861 Pylodexia uvula - Ehrenberg, C.G., K. Preuss. Akad. Wiss. Berlin, Monatsber., p. 276, 277, 308. 1873 Pylodexia uvula Ehrenberg, C.G., K. Akad. Wiss. Berlin, Abh. (1872), pl. 2, fig. 24-25. 1960 Globigerina bradyi Wiesner - Banner, F.T. and Blow, W.H., Cushm. Found. Foram. Res., Contr., 11, p. 5, pl. 3, fig. 1-2 (lectotype). 1962 Globigerinita uvula (Ehrenberg) Parker, F.L., Micropaleont., 8, p. 252, pl. 8, fig. 14-26.

The very small and slender test is high trochospiral. The wall is thin, transparent and smooth, with few pustules. The species is known mainly from colder environments; in Site 147 it occurs throughout, but is more frequent in the colder cycles. 
Globigerinita uvula minuta (Natland, 1938)

(Plate 5, Figure 25; Plate 15, Figure 8)

1933 Globigerinoides minuta - Natland, M.L., Scripps Inst. Oceanogr., Bull., Tech. Ser., 3, no. 10, line 34 of table (nom. nudum). 1938 Globigerinoides minuta - Natland, M.L., ibidem, 4, no. 5, p. 150, pl. 7, fig. 2-3. 1959 Globigerinoides cf. minuta Natland - Bradshaw, J.S., Cushm. Found. Foarm. Res., Contr., 10 , p. 40 , pl. 7 , fig. $9-11$.

A form similar to Globigerinita uvula uvula, but distinctly larger, with strongly inflated chambers and comparatively low trochospiral test, occurs in Core 2, Section $2(2-4 \mathrm{~cm}$ to the core catcher). Like G. uvula s.s., it possesses a smooth wall, which is finely perforated but with stronger incrustations of crystalline knobs. Parker includes both forms in Globigerinita uvula, with the larger sized forms restricted to warmer waters. Following Bradshaw, the distribution of the species is from subarctic to temperate.

\section{Genus PULLENIATINA Cushman, 1927}

Banner and Blow (1967) regard Pulleniatina as a descendent from Globorotalia. This finds support in the globorotaloid test shape of the early Pulleniatina obliquiloculata primalis. Wall surfaces of juvenile tests of Pulleniatina obliquiloculata obliquiloculata are pitted (Plate 15, Figures 6 and 9), as in Neogloboquadrina, but also possess short spines, which however may be secondary pseudospines. Lipps (1966) maintains that the juvenile test of Pulleniatina is spinose, whereas, Be (1967) is of the opinion that there are no spines. Brönnimann and Resig's (1971) figures indicate that the wall ornamentations are pustules or crystallites rather than spines. Compared with Globigerina the spines in juvenile Pulleniatina are very short, thick and with crystallite like points at their ends. Origin and evolution of the genus still remains doubtful and a globigerinid origin can not entirely be excluded.

\section{Pulleniatina obliquiloculata obliquiloculata}

(Parker and Jones, 1865)

(Plate 8, Figures 15-16; Plate 15, Figures 6 and 9)

1862 Pullenia obliquiloculata Parker and Jones - in Carpenter, Introduct. Foram., p. 183 (nom. nudum). 1865 Pullenia sphaeroides (d'Orb.) var. obliquiloculata - Parker, W.K. and Jones, T.R., Roy. Soc. London, Phil. Trans., 155, p. 365, 368, pl. 19, fig. 4 a-b. 1957 Pulleniatina obliqueloculata (Parker and Jones) - Bolli, H.M., Loeblich, A.R. and Tappan, H., U.S. Nat. Mus., Bull., 215, p. 33, pl. 4, fig. 3a-5 (lectotype designated, not described). 1960 Pullenia sphaeroides (d'Orb.) var obliquiloculata Parker and Jones - Banner, F.T. and Blow, W.H., Cushm. Found. Foram. Res., Contr., 11, p. 25, pl. 7, fig. 4 a-c (lectotype). 1967 Pulleniatina obliquiloculata obliquiloculata (Parker and Jones) - Banner, F.T. and Blow, W.H., Micropaleont., 13, p. 137, pl. 3, fig. 4 a-c, pl. 4, fig. 9. 1971 Pulleniatina obliquiloculata obliquiloculata (Parker and Jones) Brönnimann, P. and Resig, G.J., Init. Rept. DSDP, 7, pt. 2, p. 1318 , pl. 16 , fig. $1-11$, pl. 17 , fig. $1-4$, pl. 18 , fig. $1-7$, pl. 19 , fig. 6.

The evolution of the test from a low trochospiral early stage (Plate 15, Figure 6) to a streptospiral chamber arrangement (Plate 8, Figure 15) is demonstrated. The wall is pitted with some pustules or short spines in the early stage (Plate 15, Figure 9) to become covered in the adult by a thick cortex of glassy calcite (Plate 8, Figure 16). The species is common in Site 147 with some interruptions.

Remarks on other faunal and floral components in Site 147 residues

The biogenic remains, other than planktonic foraminifera, are also of significance for ecologic interpretation. They were investigated along with the planktonic foraminifera and their distribution included in the range chart of Site 147 (Table 2). For calcareous nannoplankton and pteropods, reference is made to the chapters by W.W. Hay and P. Jung, respectively, in this volume.
Diatomeae: They may occur in great numbers in thin intervals containing cold-water foraminiferal faunas.

Benthonic Foraminifera: Most specimens present are dwarfed and delicate. Benthonic foraminifera are poor in species and number except for small bolivinids which are common in certain samples. Arenaceous species are very scarce. The Cariaco Trench benthonic foraminifera, especially from the Gulf of Cariaco, have been published by Bermudez and Seiglie (1963), Seiglie (1964) and Seiglie and Bermudez (1963). Dr. P.J. Bermudez (Caracas) has kindly aided in the determination of the following species present in Site 147:

Clavulina mexicana Cushman.

Dorothia sp.

Karreriella bradyi (Cushman)

Martinotiella communis d'Orb.

Textularia calva Lalicker

Textularia conica d'Orb.

Cyclogyra involvens (Reuss)

Spiroloculina convexa Said

Quinqueloculina div. sp.

Quinqueloculina angulata (Williamson)

Quinqueloculina bosciana (d'Orb.)

Lagena hexagona (Williamson)

Lagena striata d'Orb.

Lagena filicosta Reuss

Dentalina communis d'Orb.

Dentalina cuvieri d'Orb.

Dentalina pauperata d'Orb.

Nodosaria pyrula d'Orb.

Astacolus crepidulus (F.\&M.)

Frondicularia sagittula Van den Broeck

Lenticulina div.sp.

Lenticulina americana americana (Cushm.)

Lenticulina american spinosa (Cushm.)

Planularia div. sp.

Saracenaria latifrons (Brady)

Ramulina globulifera (Brady)

Seabrookia sp.

Fissurina div. sp.

Buliminella elegantissima (d'Orb.)

Buliminella silviae Bermudez \& Seiglie

Tretomphalus bulloides (d'Orb.)

Bolivina div. sp.

Bolivina capitata Cushm.

Bolivina interiuncta Cushm.

Bolivina lowmanni Phleger \& Parker

Bolivina plicatella mera Cushm. \& Ponton

Bolivina spathulata (Will.)

Bolivina striatula Cushm.

Bolivina tortuosa Brady

Cassidulinoides sp.

Bulimina marginata Cushm.

Bulimina inflata Seg.

Bulimina pupoides d'Orb.

Uvigerina auberiana d'Orb.

Uvigerina peregrina Cushm.

Sagrina pulchella d'Orb.

Siphogenerina sp.

Cancris sagrai d'Orb.

Discorbis cushmani Palmer \& Bermudez 
Siphonina pulchra Cushm.

Spirillina vivipara Ehrenberg

Patellina corrugata Will.

Planulina foveolata (Brady)

Cibicides div. sp.

Fursenkoina squammosa (d'Orb.)

Loxostomum sp.

Cassidulima subglobosa (Brady)

Chilostomella oolina Schwager

Chilostomella ovoidea Reuss

Florilus grateloupi (d'Orb.)

Nonionella atlantica Cushm.

Nonionella opima Cushm.

Pullenia bulloides (d'Orb.)

Melonis affinis (Reuss)

Gyroidina sp.

Anomalina div. sp.

Hanzawaia concentrica (Cushm.)

Hoeglundia elegans (d’Orb.)

Mollusca: Juvenile stages of gastropods and bivalves are present in addition to pteropods. Fragments of adult molluscs are scarce.

Enchinodermata: Sclerites of Holothurians, spines and plates of echinoids, and fragments of Ophiuroids are comparatively frequent. Small spines (Plate 18, Figures 1 and 15) are common in the finest fraction; they were determined to be spines of ophiurian arms by H. Mostler (Innsbruck), who regards them as belonging to the Recent Ophiothela danae and Ophientrena laucostictum. Small calcareous sclerites (Plates 18, Figures 2-14), occurring in the upper part of Site 147 were determined by G. Deflandre (Paris) as internal skeletons of Echinopulteus, the planktonic larval stage of echinoids.

Other remains: There are fish bones and scales which may be common, scarce sponge spicules and sclerites of octocorallia.

\section{ACKNOWLEDGMENTS}

The writers wish to thank the Deep Sea Drilling Project for having made Site 147 samples available for the present study. The Swiss Federal Institute of Technology, Zurich, provided laboratory facilities and technical help. The Swiss National Science Foundation made it possible for one of the authors (F. Rogl) to work on the project. The authors wish to express their thanks to J.P. Beckmann for reading the manuscript and discussing its contents. Frances L. Parker, P.J. Bermudez, G. Deflandre, W.W. Hay, H. Mostler, and W.R. Riedel have contributed to this study through discussions and the determination of various fossil groups. Eva Luczkowska kindly made available comparative material from the Miocene of Poland. The scanning electron micrographs were taken by H.E. Franz.

\section{REFERENCES}

Bandy, O.L., Frerichs, W.E. and Vincent, E., 1967. Origin, development, and geologic significance of Neogloboquadrina. Bandy, Frerichs, and Vincent, gen. nov. Cushm. Found. Foram. Res., Contr. 18, 152.

Banner, F.T. and Blow, W.H., 1959. The classification and stratigraphical distribution of the Globigerinaceae. Palaeontology 2,1 .
1960. The taxonomy, morphology and affinities of the genera included in the subfamily Hastigerininae. Micropaleontology 6, 19.

W.H., 1967. The origin, evolution and taxonomy of the foraminiferal genus Pulleniatina. Cushman, 1927. Micropaleontol. 13, 133.

Bé, A.W.H., 1960. Some observations on Arctic planktonic foraminifera. Contrib. 11, 64. Cushman Found. Foram. Res.

1965. The influence of depth on shell growth in Globigerinoides sacculifer (Brady). Micropaleontology 11,81 .

1967. Foraminifera. Families: Globigerinidae and Globorotaliidae. Fiches d'ident. Zooplancton, Charlottenlund Slot, Danemark, Sheet 108

1969. Planktonic foraminifera. Antarctic Map Folio Ser. Geogr. Soc. 11, 9.

Bé, A.W.H. and Hemleben, G., 1970. Calcification in a living foraminifer, Globigerinoides sacculifer (Brady). N. Jb. Geol. PaTāont., Abh. 134, 221.

Bé, A.W.H. and Tolderlund, D.S., 1971. Distribution and ecology of living planktonic foraminifera in surface waters of the Atlantic and Indian oceans. In Funnel, B.M. and Riedel, W.R. Micropaleontology of Oceans. London (Cambridge Univ. Press) 105.

Bermudez, P.J., 1961. Contribucion al estudio de las Globigerinidea de la region Caribe - Antillana (Paleoceno - Reciente). Mem. 3d Congr. Geol. Venez. Bol. Geol., Caracas. 1119.

Bermudez, P.J. and Bolli, H.M., 1969. Consideraciones sobre los sedimentos del Mioceno Medio al Reciente de las costas central y oriental de Venezuela. Bol. Geol., Caracas. 10 (20), 137.

Bermudez, P.J. and Seiglie, G.A., 1963. Estudio sistematico de los Foraminiferos del Golfo de Cariaco. Inst. Oceanogr. Univ. Oriente, Bol., Cumana, 2(2), 3.

Blow, W.H., 1965. Clavatorella, a new genus of the Globorotaliidae. Micropaleontology. 11, 365.

1969. Late Middle Eocene to Recent Planktonic foraminiferal biostratigraphy. Proc. 1st Int. Conf. Plankt. Microfoss., Geneva 1967. 199.

Blow, W.H. and Banner, F.T., 1962. The Mid-Tertiary (Upper Eocene to Aquitanian) Globigerinaceae. In Eames, F.E., Banner, F.T., Blow, W.H. and Clarke, W.J., (Eds.) 1962. Fundamentals of Mid-Tertiary stratigraphical correlation. Cambridge, Univ. Press, 61.

Bolli, H. M., 1970. The foraminifera of Sites $23-31$, Leg 4. In Bader, R.G., Gerard, R.D. et al., 1970. Initial Reports of the Deep Sea Drilling Project, Volume IV. Washington (U.S. Government Printing Office). 577.

Bolli, H.M. Loeblich, A.R., Jr. and Tappan, H., 1957. Planktonic foraminiferal families Hantkeninidae, Orbulinidae, Globorotaliidae and Globotruncanidae. Bull. U.S. Nat. Mus. 215, 3.

Boltovskoy, E., 1969. Living planktonic foraminifera at the $90^{\circ} \mathrm{E}$ meridian from the equator to the Antarctic. Micropaleontology 15, 237.

Bradshaw, J.S., 1959. Ecology of living planktonic foraminifera in the north and equatorial Pacific Ocean. Contrib., Cushman Found. Foram. Res. 10, 25.

Brönnimann, P. and Resig, J., 1971. A Neogene Globigerinacean biochronologic time-scale of the Southwestern Pacific. In Winterer, E.L. et al., (Eds.) Initial Reports of the Deep Sea Drilling Project, Volume VII (2). Washington (U.S. Government Printing Office) 1235 . 
Chapman, F.J., 1902. On the foraminifera collected round the Funafuti Atoll from shallow and moderately deep water. Linn. Soc. London, J., Zool. 28(184), 410.

Cifelli, R., 1971. On the temperature relationships of planktonic foraminifera. J. Foram. Res. 1(4), 170.

Cifelli, R, and Smith, R.K., 1971. Distribution of planktonic foraminifera in the vicinity of the North Atlantic Current. Smithson. Contr. Paleobiol. 4, 1.

Cita, M.B., 1971. Biostratigraphy, chronostratigraphy and paleoenvironment of the Pliocene of Cape Verde (North Atlantic). Rev. Micropaleontol. 14(5), 17.

El-Naggar, Z.R., 1971. On the classification, evolution and stratigraphical distribution of the Globigerinacea. Proc. 2nd Plankt. Conf., Roma 1970.

Emiliani, C., 1966. Paleotemperature analysis of Caribbean cores P 6304-8 and P 6304-9 and a generalized temperature curve for the past 425,000 years. J. Geol. 74(2), 109.

$$
15,265 \text {. }
$$

Ericson, D.B. and Wollin, G., 1956a. Correlation of six cores from the equatorial Atlantic and the Caribbean. Deep-Sea Res. 3, 104.

1956b. Micropaleontological and isotopic determinations of Pleistocene climates. Micropaleontology 2, 257.

, 1968. Pleistocene climates and chronology in deep-sea sediments. Science 162, 1227.

Ericson, D. B., Ewing, M., Wollin, G. and Heezen, B. C., 1961. Atlantic deep-sediment cores. Bull. Geol. Soc. Am. 72, 193.

Gade, H.G., 1961. On some oceanographic observations in the southeastern Caribbean Sea and adjacent Atlantic Ocean with special reference to the influence of the Orinoco River. Bol. Inst. Oceanogr. Univ. Oriente, 1(2), 287.

Hemleben, C., 1969. Zur Morphogenese planktonischer Foraminiferen. Zitteliana, München. 1, 91.

Kennett, J.P., 1968. Latitudinal variation in Globigerina pachyderma (Ehrenberg) in surface sediments of the southwest Pacific Ocean. Micropaleontology 14, 305. 1970. Comparison of Globigerina pachyderma (Ehrenberg) in Arctic and Antarctic areas. Contrib. Cushman Found. Foram. Res. 21, 47.

Lipps, J. H., 1966. Wall structure, systematics, and phylogeny studies of Cenozoic planktonic foraminifera. J. Paleont. 40, 1257.
Loeblich, A.R., Jr. and Tappan, H., 1964. Protista 2, Sarcodina chiefly "Thecamoebians" and Foraminiferida. In Moore, R.C., Treatise on Invertebrate Paleontology, Part C. 1-2.

Miro, M. D. de, 1971. Los foraminiferos planctonicos vivos y sedimentados del margin continental de Venezuela (resumen). Acta Geol. Hisp. Barcelona. 6 (4), 102.

Miro Orell, M. de, 1971. Morfologia submarina y sedimentos marinos recientes del margin continental del nororiente de Venezuela (resumen). Acta Geol. Hisp. Barcelona. 6 (1), 24.

Parker, F.L., 1962. Planktonic foraminiferal species in Pacific sediments. Micropaleontology 8, 219.

Reiss, Z., Merling - Reiss, P. and Moshkovitz, S., 1971. Quaternary planktonic Foraminiferida and nannoplankton from the Mediterranean continental shelf and slope of Israel. Israel J. Earth-Sci. 20, 141.

Richards, F.A., 1960. Some chemical and hydrographic observations along the north coast of South America. I. Cabo Tres. Punts to Curacao, including the Cariaco Trench and the Gulf of Cariaco. Deep-Sea Res. 7, 163.

Richards, F.A. and Vaccaro, R.F., 1956. The Cariaco Trench, an anaerobic basin in the Caribbean Sea. Deep-Sea Res. 3, 214.

Seiglie, G.A., 1963. Una nueva especie del genero Globigerina del Reciente de Venezuela. Bol. Inst. Oceanogr. Univ. Oriente. 2(1), 89.

1964. Algunos Foraminiferos arenaceos recientes de Venezuela. Bol. Inst. Oceanogr. Univ. Oriente. 3(1-2), 5.

Seiglie, G.A. and Bermudez, P.J., 1963. Distribucion de los Foraminiferos del Golfo de Cariaco. Bol. Inst. Oceanogr. Univ. Oriente. 2(1), 5.

Thiede, J., 1971. Plaktonische Foraminiferen in Sedimenten vom ibero-marokkanischen Kontinentalrand. Meteor Forsch.-Ergeb., Reihe C. 7, 15.

Wollin, G., Ericson, D.B. and Ewing, M., 1971. Late Pleistocene climates recorded in Atlantic and Pacific deep-sea sediments. In Turekian, K.K., The Late Cenozoic glacial ages. London (Yale Univ.) 199.

Zobel, B., 1968. Phänotypische Varianten von Globigerina dutertrei d'Orbigny (Foram.); ihre Bedeutung für die Stratigraphie in quartären Tiefsee - Sedimenten. Geol. Jb., 85,97 .

1971. Foraminifera from plankton tows, Arabian Sea; areal distribution as influenced by Ocean water masses. Proc. 2nd Plankt. Conf., Roma 1970. 1323. 

TABLE 2

Distribution of Microfossils

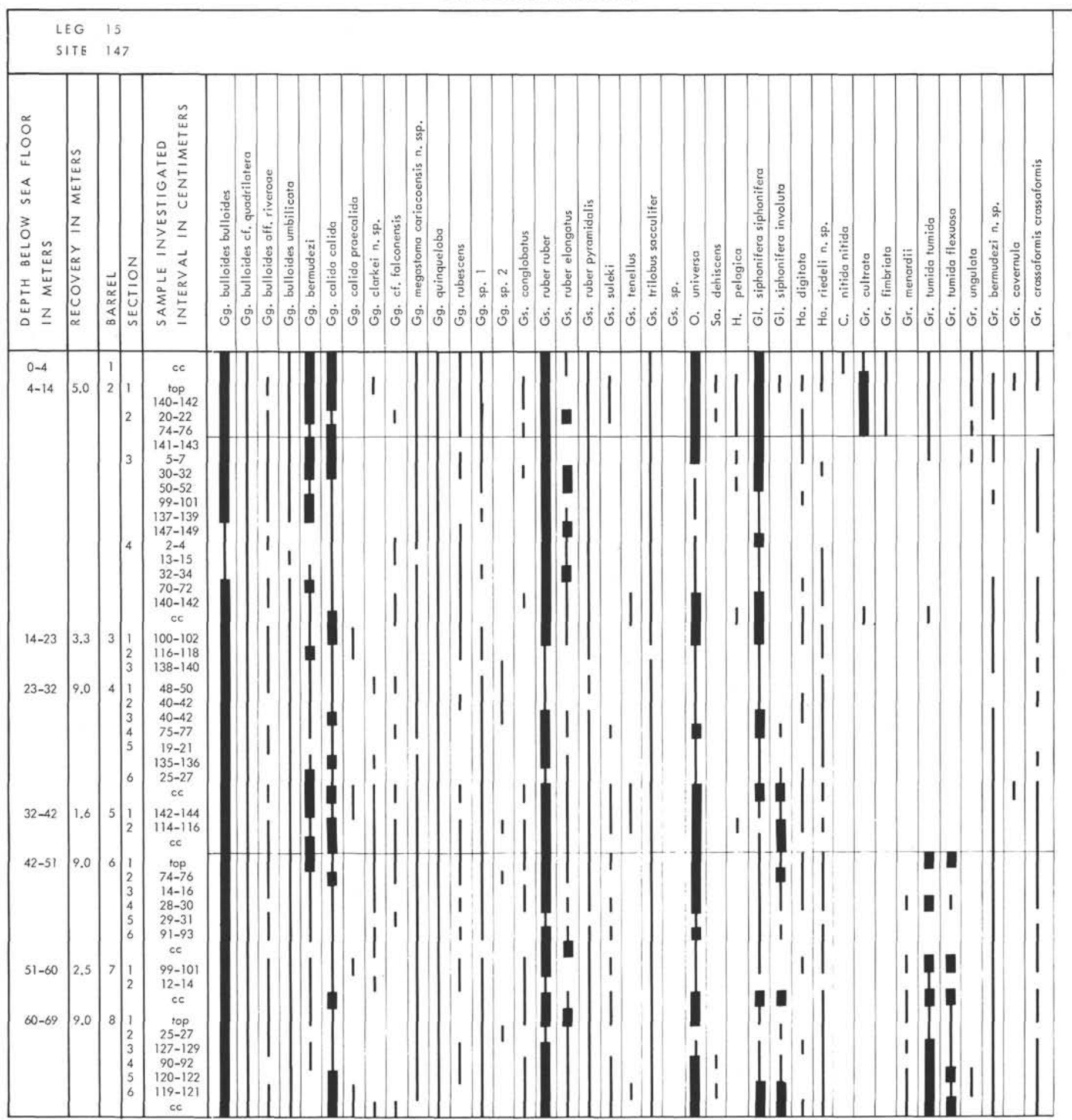


TABLE 2 - Continued

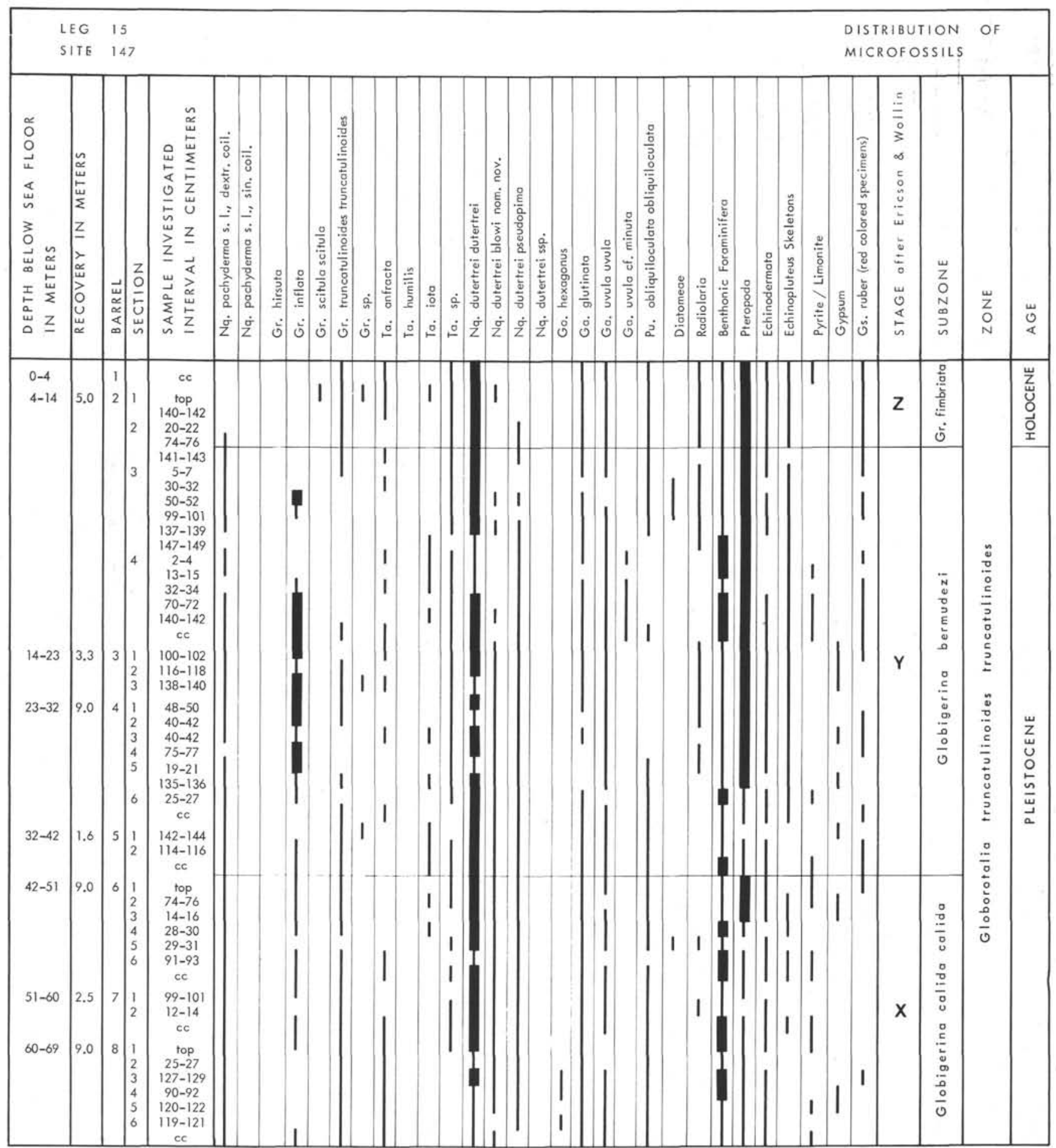




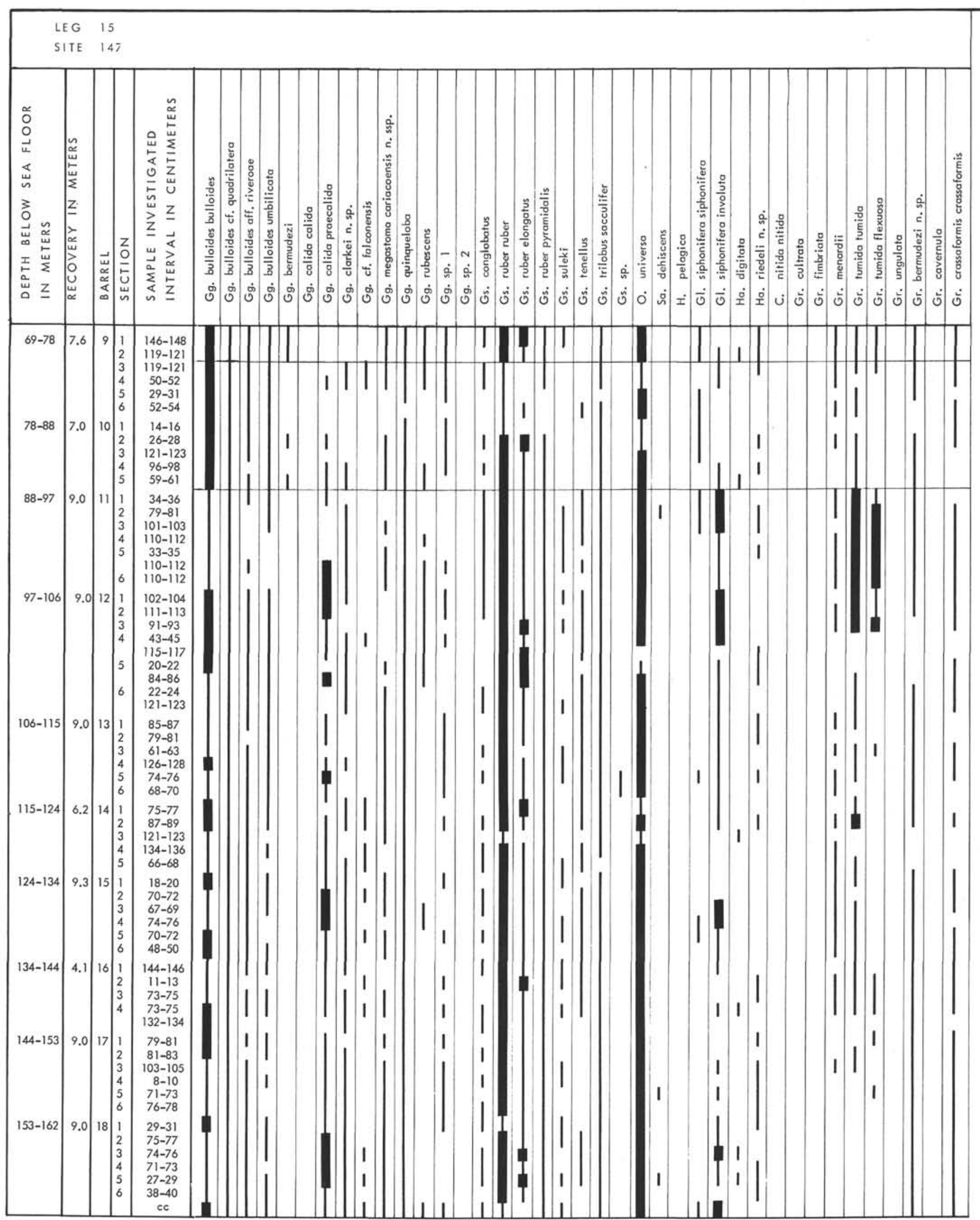


LEG 15

SITE 147
DISTRIBUTION OF

MICROFOSSILS

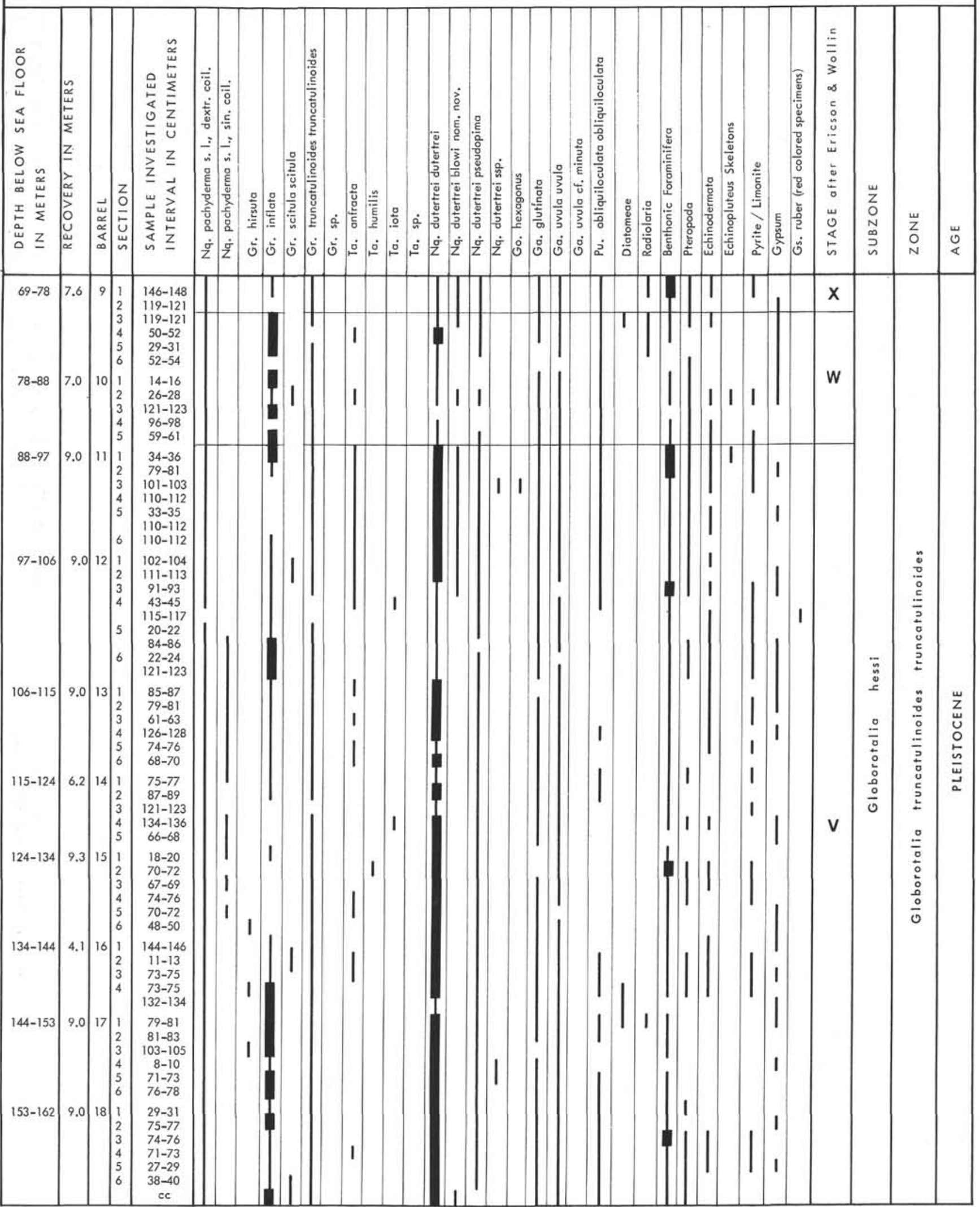




\section{PLATE 1}

All figures $100 \times$.

Figures 1.4 Globigerina bulloides bulloides d'Orb.; juvenile. From Site 147, Core 2, Section 1 (top). Globorotalia fimbriata Subzone: Holocene.

Figure 1: Umbilical view (NMB C-26957). Figure 2: Spiral view (NMB C-26958). Figure 3: Spiral view, with secondary aperture (NMB C-26956); see Plate 12, Figure 8. Figure 4: Side view (NMB C-26959).

Figures 5-7 Globigerina bulloides bulloides d'Orb.; adult. From Site 147, Core 2, Section 1 (top). Globorotalia fimbriata Subzone; Holocene.

Figure 5: Umbilical view (NMB C-26952). Figure 6: Spiral view (NMB C-26953). Figure 7: Side view (NMB C-26946).

Figure 8-9 Globigerina bulloides bulloides d'Orb. From Site 147, Core 18, Section $1(29-31 \mathrm{~cm})$. Globorotalia hessi Subzone; Pleistocene.

Figure 8: Spiral view (NMB C-27115). Figure 9: Umbilical view (NMB C-27114).

Figure 10

Globigerina bulloides aff. riveroae Bolli \& Bermudez; umbilical view (NMB C-27116). From Site 147, Core 9, Section $2(119-121 \mathrm{~cm})$. Globorotalia hessi Subzone; Pleistocene.

Figure $11 \quad$ Globigerina bulloides bulloides d'Orb; umbilical view (NMB C-26951). See Plate 12, Figure 1. From Site 147, Core 2, Section 1 (top). Globorotalia fimbriata Subzone; Holocene.

Figures 12-16 Globigerina bulloides cf. quadrilatera Galloway \& Wissler. From Site 147, Core 2, Section 1 (top). Globorotalia fimbriata Subzone; Holocene.

Figure 12: Umbilical view (NMB C-26955). Figure 13: Umbilical view (NMB C-26949). Figure 14: Spiral view (NMB C-26954). Figure 15: Side view (NMB C-26947). Figure 16: Spiral view (NMB C-26948), see Plate 12, Figures 2-3 and 7.

Figures 17-18 Globigerina intermediate between $G$. bulloides bulloides and $G$. bulloides umbilicata. From Site 147, Core 2, Section 1 (top). Globorotalia fimbriata Subzone; Holocene.

Figure 17: Umbilical view (NMB C-26966). Figure 18: Umbilical view (NMB C-26943).

Figures 19-20 Globigerina bulloides umbilicata Orr \& Zaitzeff. From Site 147, Core 2, Section 1 (top). Globorotalia fimbriata Subzone; Holocene.

Figure 19: Umbilical view (NMB C-26969). Figure 20: Spiral view (NMB C-26971).

Figure 21 Globigerina intermediate between $G$. bulloides bulloides and $G$. bermudezi; umbilical view (NMB C-26965). From Site 147, Core 2, Section 1 (top). Globorotalia fimbriata Subzone; Holocene.

Figures 22-24 Globigerina bulloides umbilicata Orr \& Zaitzeff. From Site 147, Core 2, Section 1 (top). Globorotalia fimbriata Subzone; Holocene.

Figure 22: Umbilical view (NMB C-26968). Figure 23: Umbilical view (NMB C-26970). Figure 24: Spiral view, with secondary apertures (NMB C-26967); see Plate 11, Figure 13. 
PLATE 1
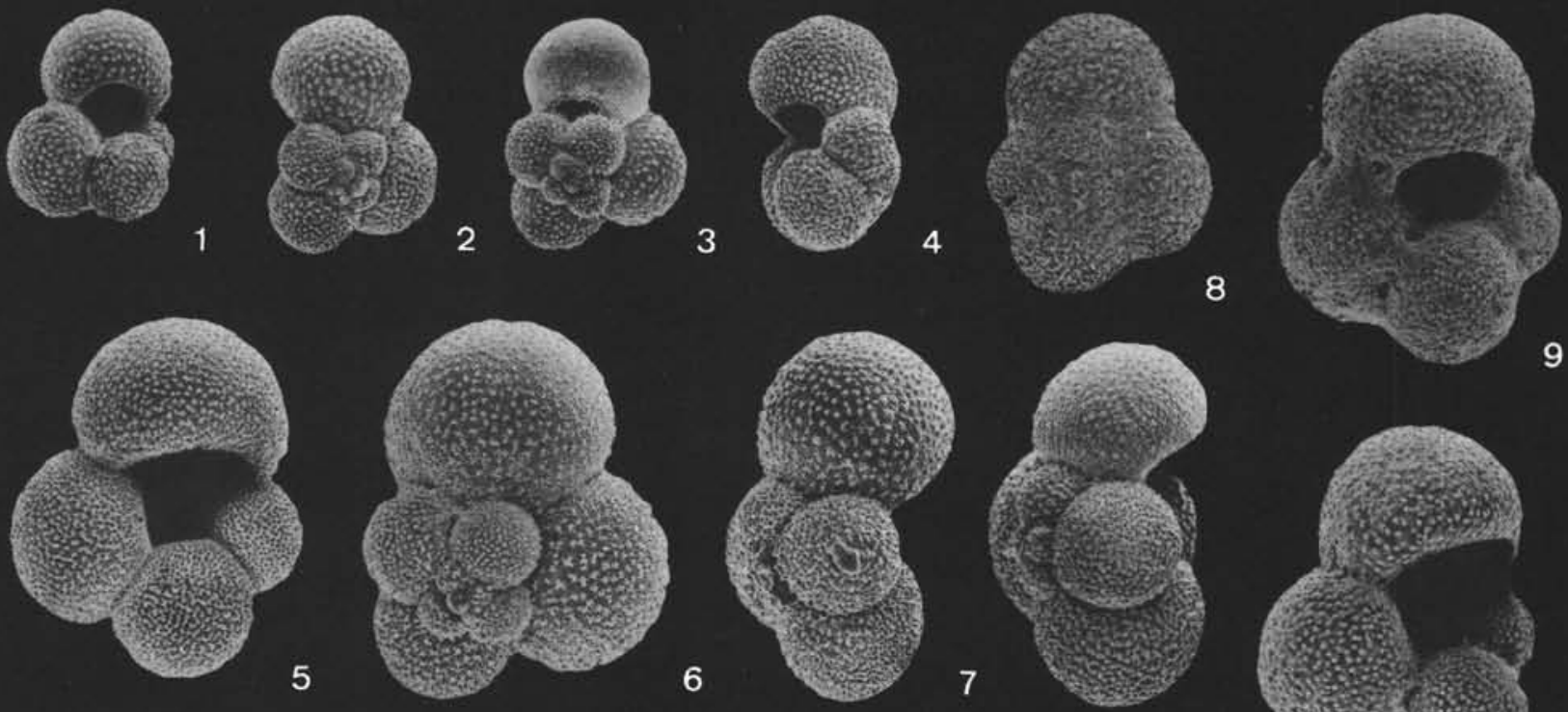

15
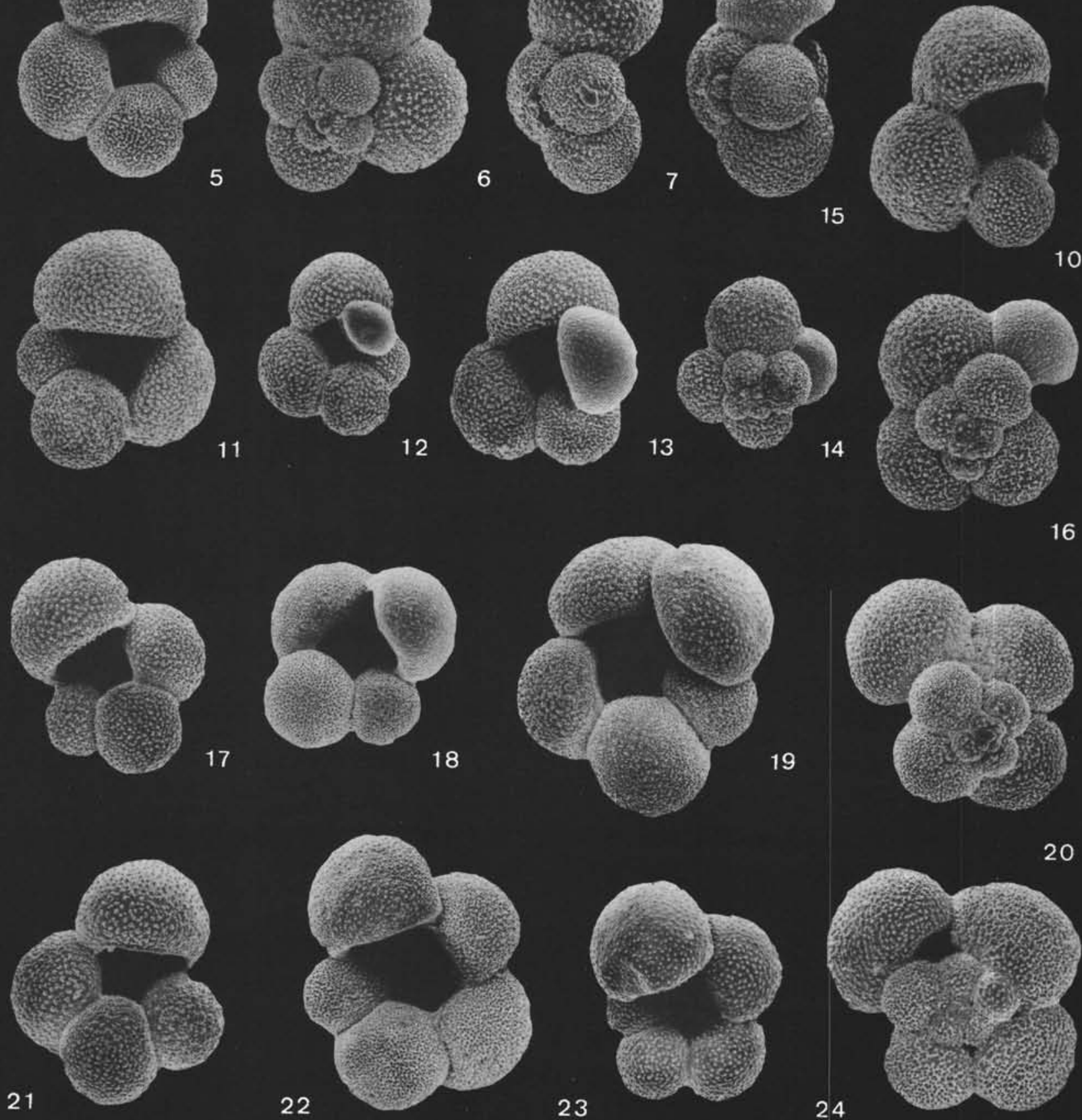

23

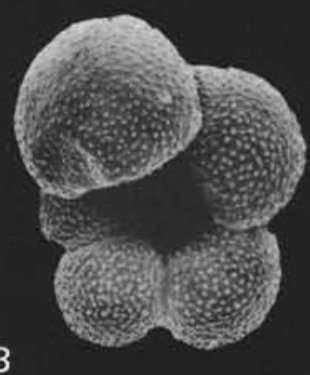

20 


\section{PLATE 2}

Figures 1-10 Globigerina megastoma cariacoensis Rögl and Bolli n. ssp. From Site 147, Core 2, Section 1 (top). Globorotalia fimbriata Subzone; Holocene. Figures 1 through 7: 100X; Figures 8 through 10: 75X.

Figure 1: Umbilical view (NMB C-26964). Figure 2: Spiral view (NMB C-26962); holotype. Figure 3: Side view (NMB C-26961). Figure 4. Side view (NMB C-26981). Figure 5: Side view (NMB C-26986). Figure 6: Side view (NMB C-26982). Figure 7: Side view (NMB C-26983); see Plate 12, Figures 5-6. Figure 8: Side view (NMB C-27081). Figure 9: Side view (NMB C-27082). Figure 10: Oblique umbilical view (NMB C-27083). From Site 147, Core 2, Section 1 (top). Globorotalia fimbriata Subzone; Holocene. Figures 1 through 7: 100X; Figures 8 through 10: $75 \mathrm{X}$.

Figures 11-19 Globigerina bermudezi Seiglie. From Site 147, Core 2, Section 1 (top). Globorotalia fimbriata Subzone; Holocene. All figures (11-19) 75X.

Figure 11: Umbilical view (NMB C-26980). Figures 12: Spiral view (NMB C-26972). Figure 13: Side view (NMB C-26985). Figure 14: Umbilical view, partially detached final chamber (NMB C-26974). Figure 15: Umbilical view (NMB C-26984); see Plate 12, Figure 4. Figure 16: Umbilical view, specimen with large secondary spiral aperture (NMB C-26979). Figure 17: Spiral view, with large secondary aperture (NMB C-26978). Figure 18: Oblique umbilical view, partially detached final chamber (NMB C-26977). Figure 19: Oblique umbilical view, partially detached final chamber (NMB C-26976).

Figure $20 \quad$ Globigerina cf. falconensis Blow. Umbilical view (NMB C-27120); see Plate 13, Figure 1. From Site 147, Core 5, Section $2(114-116 \mathrm{~cm})$. Globigerina bermudezi Subzone; Late Pleistocene. 100X.

Figures 21-23 Globigerina sp. 1. From Site 147, Core 9, Section $2(119-121 \mathrm{~cm})$. Globorotalia hessi Subzone; Pleistocene. All figures (21-23): 100X.

Figure 21: Spiral view (NMB C-27119). Figure 22: Umbilical view (NMB C-27118); see Plate 11, Figure 14. Figure 23: Umbilical view (NMB C-27117).

Figures 24-26 Globigerina sp. 2. From Site 147, Core 3, Section $3(138-140 \mathrm{~cm})$. Globigerina bermudezi Subzone; Late Pleistocene. All figures (24 through 26): 100X.

Figure 24: Umbilical view, with removed bulla like final chamber (NMB C-27132); see Plate 11, Figure 15. Figure 25: Oblique spiral view (NMB C-27134). Figure 26: Oblique umbilical view, to see second bulla like chamber (NMB C-27133). 
PLATE 2
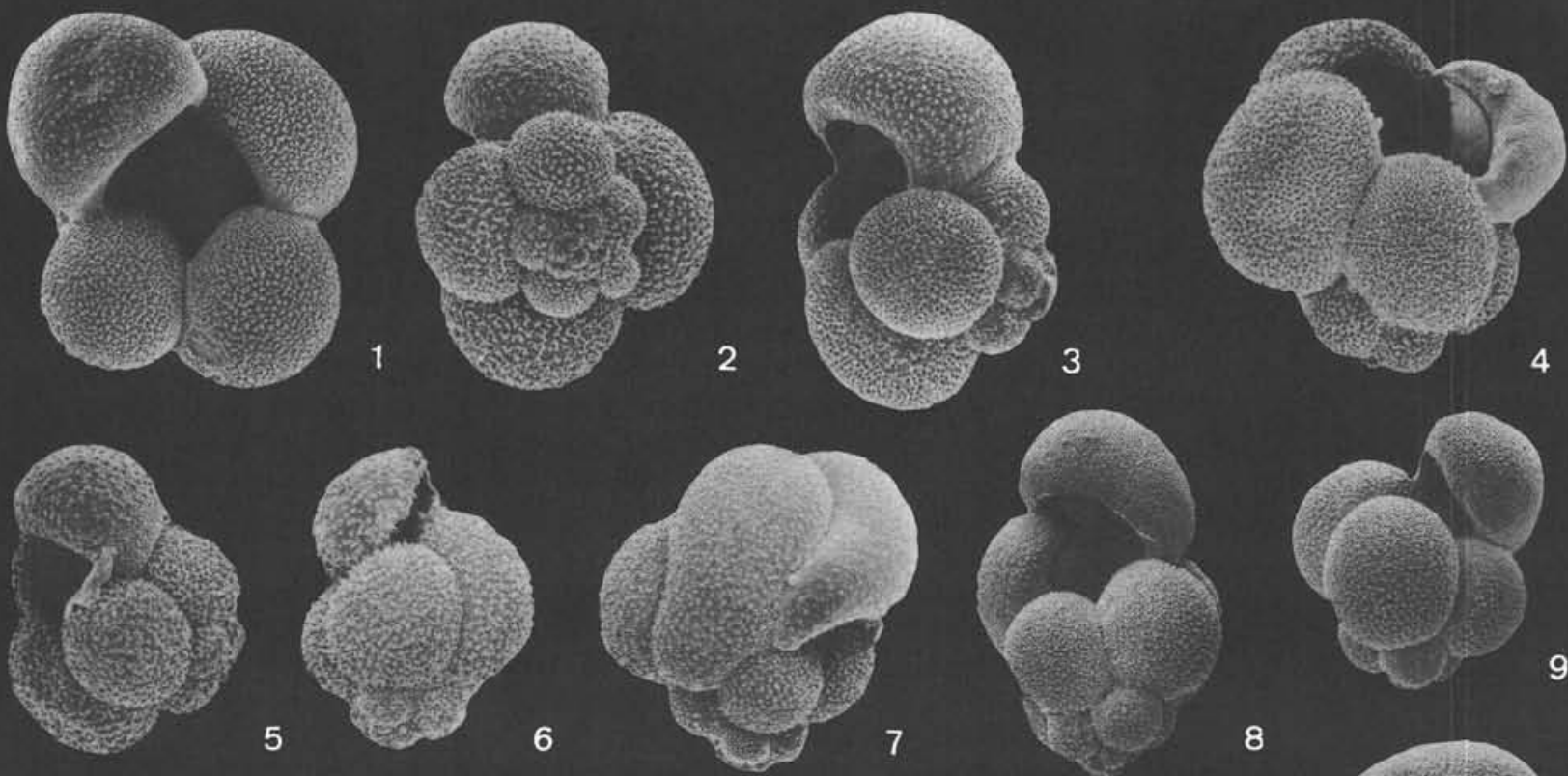

8
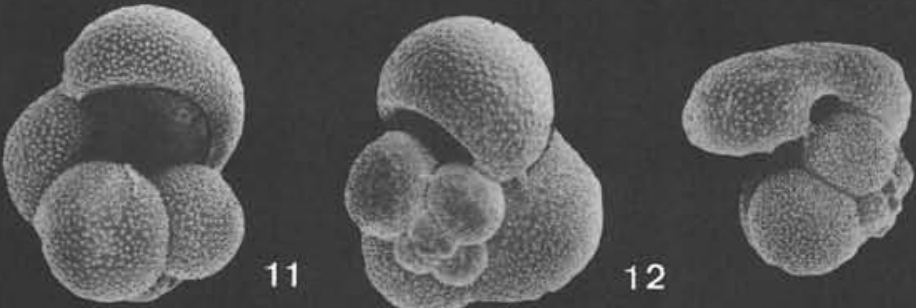

13
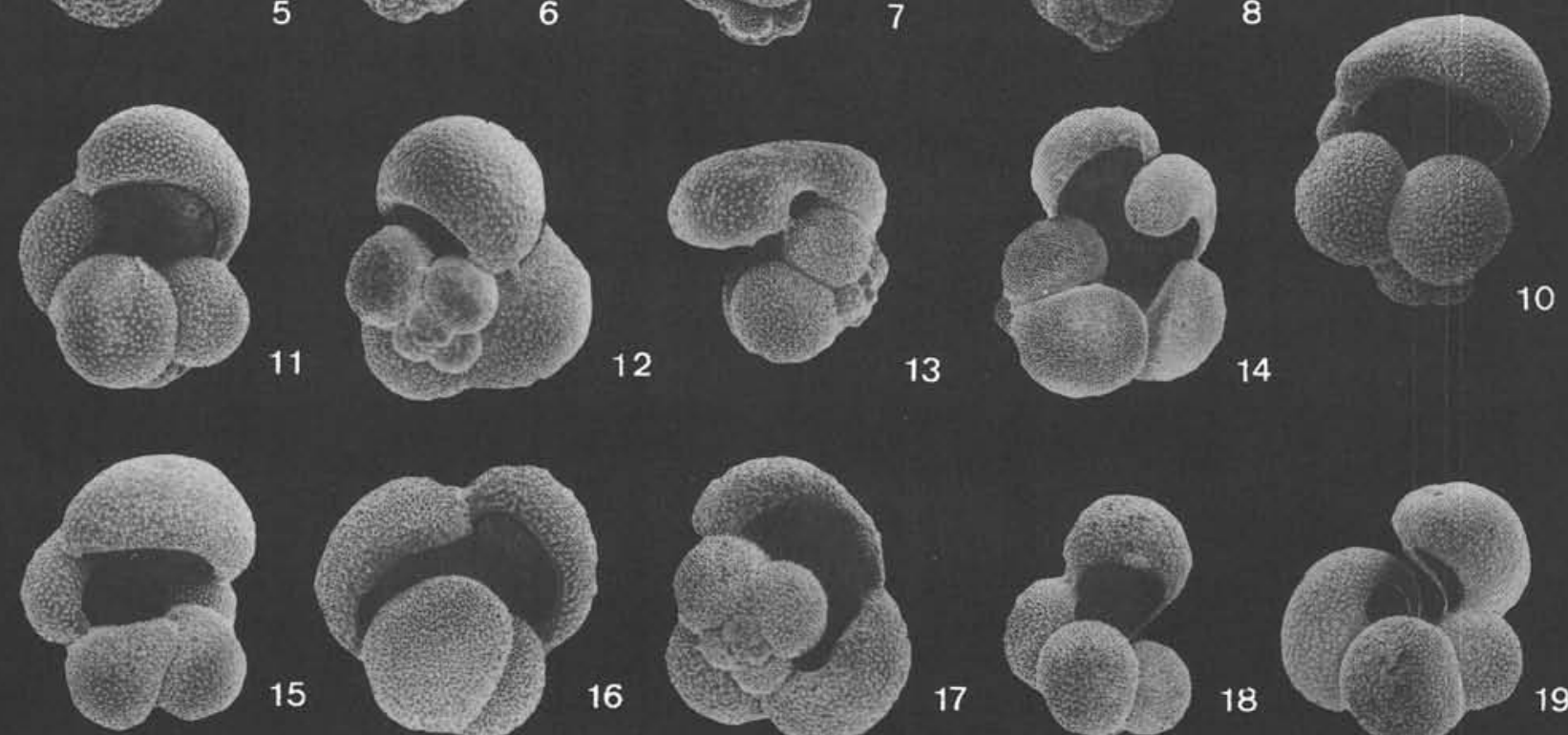

15

16
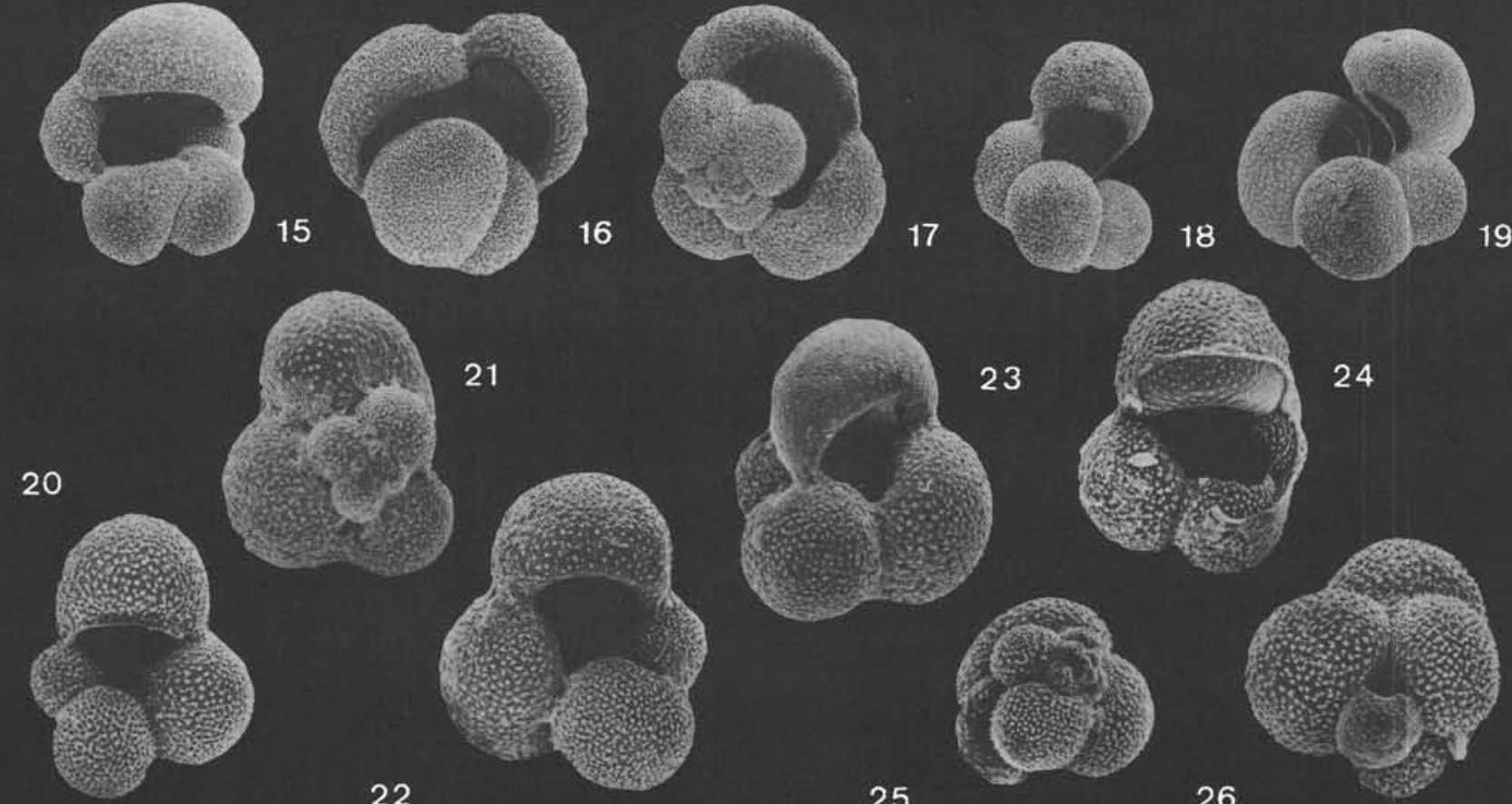

22

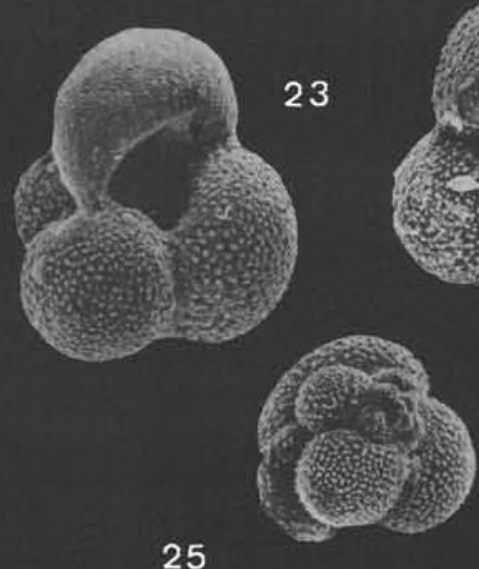

26 


\section{PLATE 3}

Figures 1-8 Globigerina calida calida Parker. From Site 147, Core 2, Section 1 (top). Globorotalia fimbriata Subzone; Holocene. Figures 1 through 5: 100X; Figures 6 through 8: $75 \times$.

Figure 1: Umbilical view, juvenile specimen (NMB C-27016); see Plate 12, Figure 9. Figure 2: Umbilical view (NMB C-27020). Figure 3: Umbilical view, near to G. calida praecalida (NMB C-27017); see Plate 12, Figure 10. Figure 4: Umbilical view (NMB C-27018). Figure 5: Umbilical view (NMB C-27019). Figure 6: Umbilical view (NMB C-27021); see Plate 12, Figure 12. Figure 7: Umbilical view (NMB C-27023). Figure 8: Spiral view (NMB C-27022); see Plate 12, Figure 11.

Figures 9-13. Globigerina calida praecalida Blow. From Site 147, Core 8 (core catcher). Boundary Globorotalia hessi/Globigerina calida calida Subzone; Pleistocene. All figures (9 through 13): $75 \mathrm{X}$.

Figure 9: Umbilical view (NMB C-27198). Figure 10: Spiral view (specimen destroyed). Figure 11: Spiral view (NMB C-27197); see Plate 13, Figure 2. Figure 12: Umbilical view (NMB C-27195). Figure 13: Side view (NMB C-27196).

Figures 14-15 Globigerinella siphonifera siphonifera (d'Orb.). From Site 147, Core 2, Section 1 (top). Globorotalia fimbriata Subzone; Holocene. Figure 14: $75 \times$; Figure 15: 50X.

Figure 14: Equatorial view, juvenile specimen (NMB C-27026). Figure 15: Equatorial view, adult specimen (NMB C-27025).

Figure 16 Globigerinella siphonifera involuta (Cushman); equatorial view (NMB C-27024); see Plate 13, Figure 5. From Site 147, Core 2, Section 1 (top). Globorotalia fimbriata Subzone, Holocene. $75 \mathrm{X}$.

Figures 17-18 Globigerinella siphonifera involuta (Cushman). From Site 147, Core 8 (core catcher). Boundary Globorotalia hessi/Globigerina calida calida Subzone; Pleistocene. Figure 17: 50X; Figure 18: 75X.

Figure 17: Lateral view (NMB C-27200). Figure 18: Equatorial view (NMB C-27201).

Figure 19 Globigerinella siphonifera siphonifera (d'Orb.); equatorial view, juvenile specimen, with shrunken final chamber, supported by strong triradiate spines (NMB C-27027); see Plate 13, Figure 4. From Site 147, Core 2, Section 1 (top). Globorotalia fimbriata Subzone; Holocene. 100X.

Figures 20-23 Hastigerina pelagica (d'Orb.). From Site 147, Core 2, Section 1 (top). Globorotalia fimbriata Subzone; Holocene. Both figures (22 and 23): $50 \times$.

Figure 20: Lateral view (NMB C-27048). Figure 21: Equatorial view (NMB C-27029); see Plate 13, Figure 10. Figure 22: Equatorial view, gerontic specimen (NMB C-27050). Figure 23: Lateral view, gerontic specimen (NMB C-27030); see Plate 13, Figure 11. 


\section{PLATE 3}
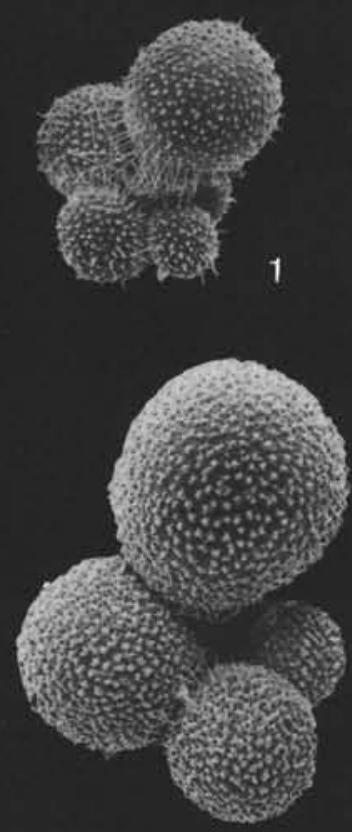

5
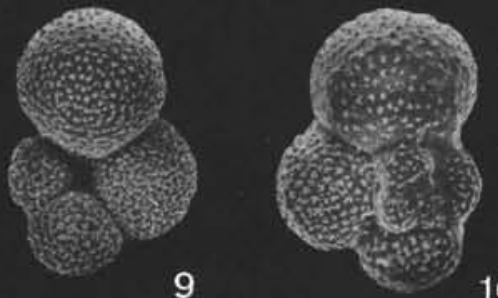

10

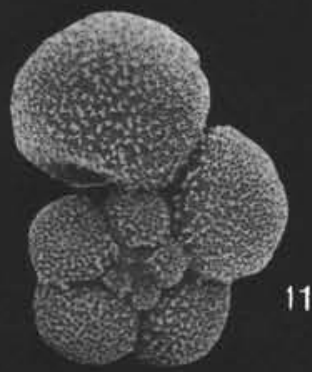

11
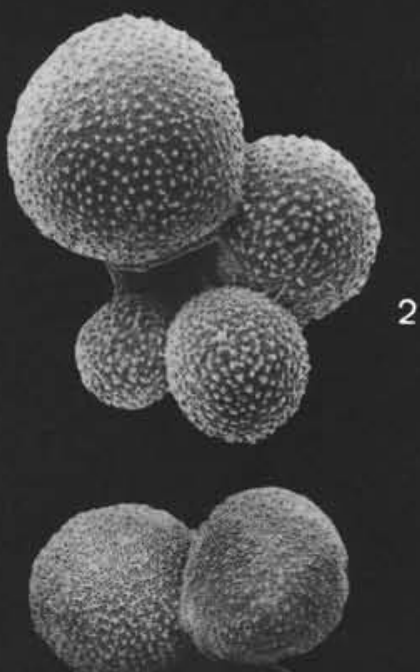

9
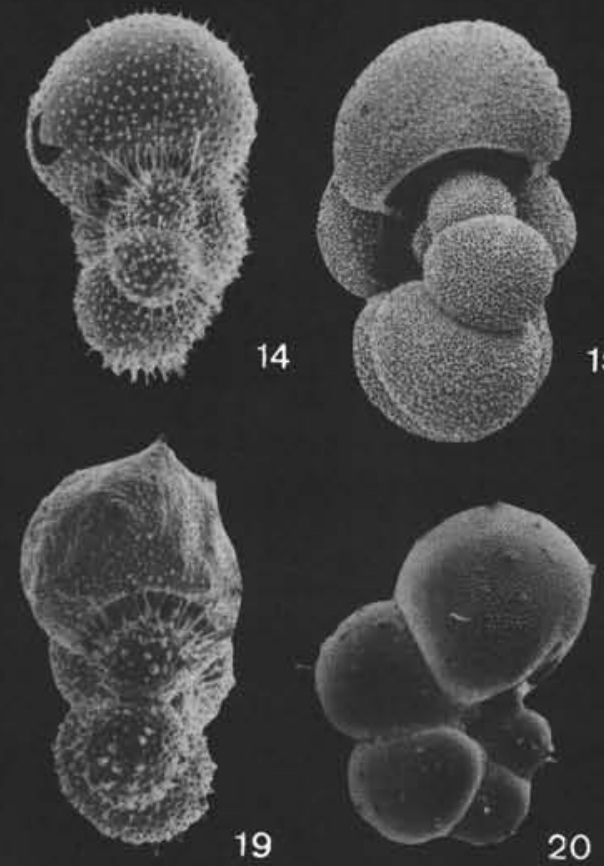

15

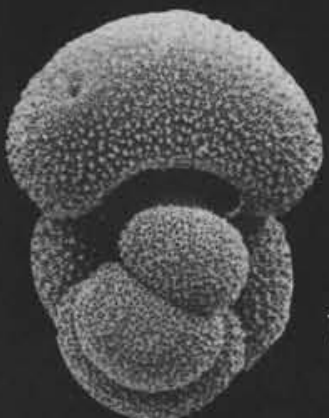

16

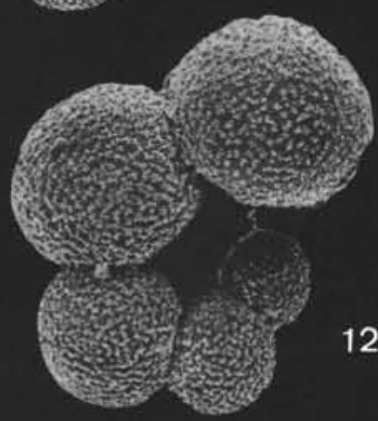

12

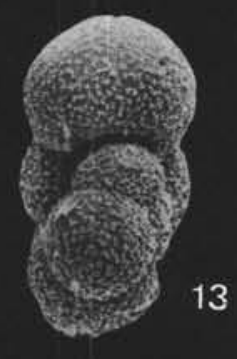

13
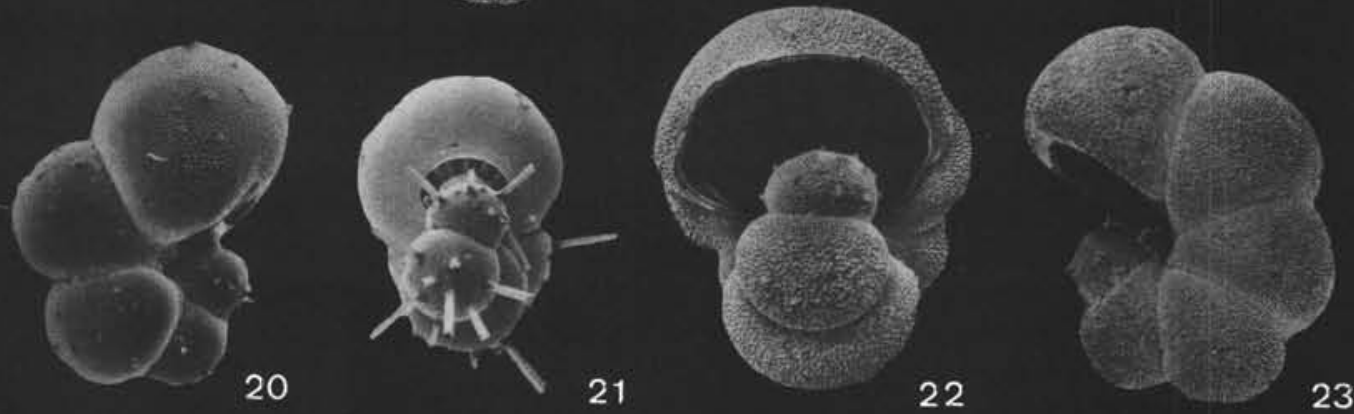


\section{PLATE 4}

Figure 1 Hastigerinella riedeli Rögl and Bolli, n. sp; umbilical view (NMB C-27162); see Plate 14, Figure 1. From Site 147, Core 2, Section 1 (top). Globorotalia fimbriata Subzone; Holocene. 250X.

Figures 2-5 Hastigerinella riedeli Rögl and Bolli, n. sp. From Site 147, Core 6 (core catcher). Globigerina calida calida Subzone; Pleistocene. Figures 2 through 4: 250X; Figure 5: 200X.

Figure 2: Side view (NMB C-27164), holotype. Figure 3: Spiral view (NMB C-27163). Figure 4: Umbilical view (NMB C-27165); see Plate 14, Figures 1 and 3. Figure 5: Spiral view (NMB C-27170).

Figures 6-9 Globigerina rubescens Hofker. From Site 147, Core 2, Section 1 (top). Globorotalia fimbriata Subzone; Holocene. All figures (6 through 9): $100 \times$.

Figure 6: Umbilical view (NMB C-27084). Figure 7: Side view (NMB C-27085). Figure 8: Spiral view (NMB C-27000); see Plate 13, Figure 3. Figure 9: Spiral view, specimen with secondary aperture (NMB C-27129).

Figures 10-12 Globigerina quinqueloba Natland. From Site 147, Core 2, Section 1 (top). Globorotalia fimbriata Subzone; Holocene. All figures (10 through 12): $150 \mathrm{X}$.

Figure 10: Umbilical view (NMB C-27105). Figure 11: Spiral view (NMB C-27222). Figure 12: Side view (NMB C-27106).

Figures 13-15 Globigerina clarkei Rögl and Bolli, n. sp. From Site 147, Core 4 (core catcher). Globigerina bermudezi Subzone; Late Pleistocene. All figures (13 through 15): $250 \mathrm{X}$.

Figure 13: Umbilical view (NMB C-27171). Figure 14: Spiral view (NMB C-27173), holotype. Figure 15: Umbilical view (NMB C-27172).

Figure 16 Hastigerinella digitata (Brady); umbilical view, juvenile specimen (NMB C-26989); see Plate 13, Figure 6. From Site 147, Core 2, Section 1 (top). Globorotalia fimbriata Subzone; Holocene. 100X.

Figure 17 Hastigerinella digitata (Brady); umbilical view, adult specimen, spines visible at thirdlas chamber (NMB C-27121); see Plate 13, Figure 7-9. From Site 147, Core 2, Section $2(20-22 \mathrm{~cm})$. Globorotalia fimbriata Subzone; Holocene. $75 \times$.

Figures 18-20 Orbulina universa d'Orb. From Site 147, Core 2, Section 1 (top). Globorotalia fimbriata Subzone; Holocene. Figures (18 through 20): $75 \times$.

Figure 18: Fine perforated specimen (NMB C-27044); see Plate 14, Figure 4. Figure 19: Coarsely perforated specimen (NMB C-27045); see Plate 74, Figure 5. Figure 20: Coarsely perforated small specimen (NMB C-27043).

Figure $21 \quad$ Orbulina universa d'Orb; thickwalled, small specimen (NMB C-27221); see Plate 74, Figure 6. From Site 147, Core 12, Section 6 (121-123 cm) Globorotalia hessi Subzone; Pleistocene.

Figure 22 Globigerinoides conglobatus (Brady); umbilical view (NMB C-27199). From Site 147, Core 8 (core catcher). Boundary Globorotalia hessi/ Globigerina calida calida Subzone; Pleistocene. 50X.

Figure 23 Globigerinoides suleki Bermudez; umbilical view (NMB C-26988); see Plate 15, Figure 3. From Site 147, Core 2, Section 1 (top). Globorotalia fimbriata Subzone; Holocene. $100 \times$. 


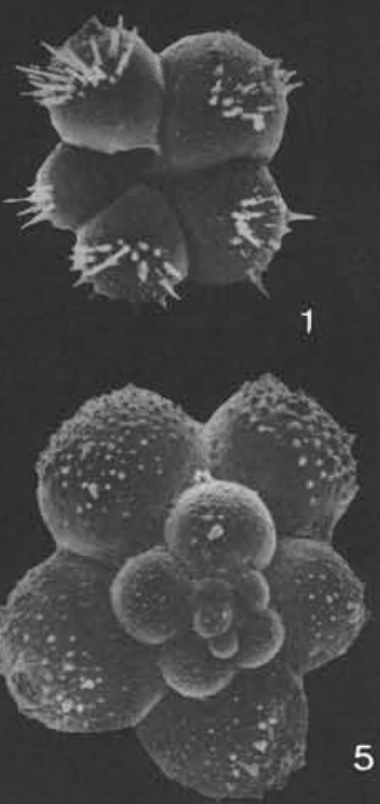

PLATE 4
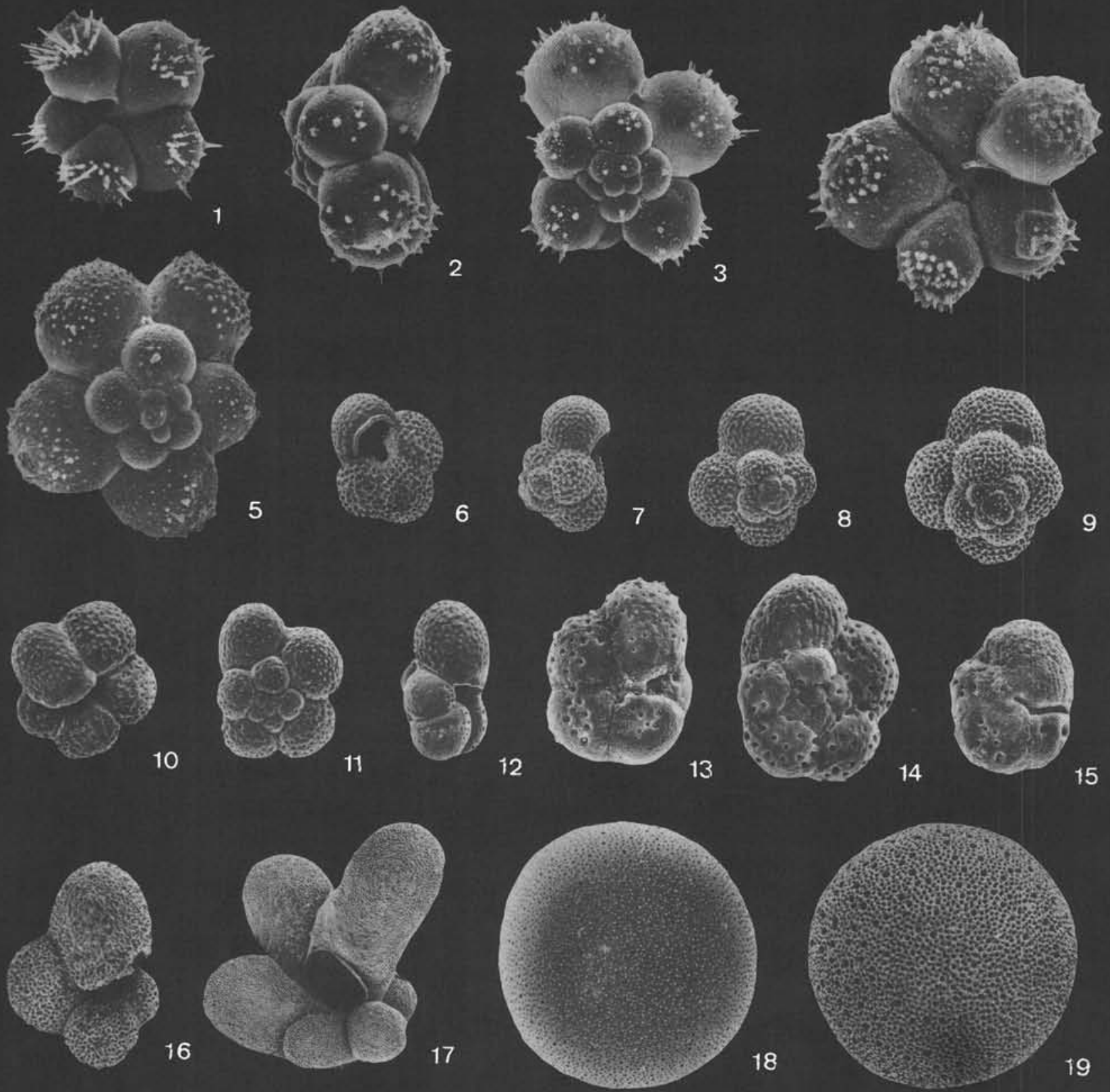

18
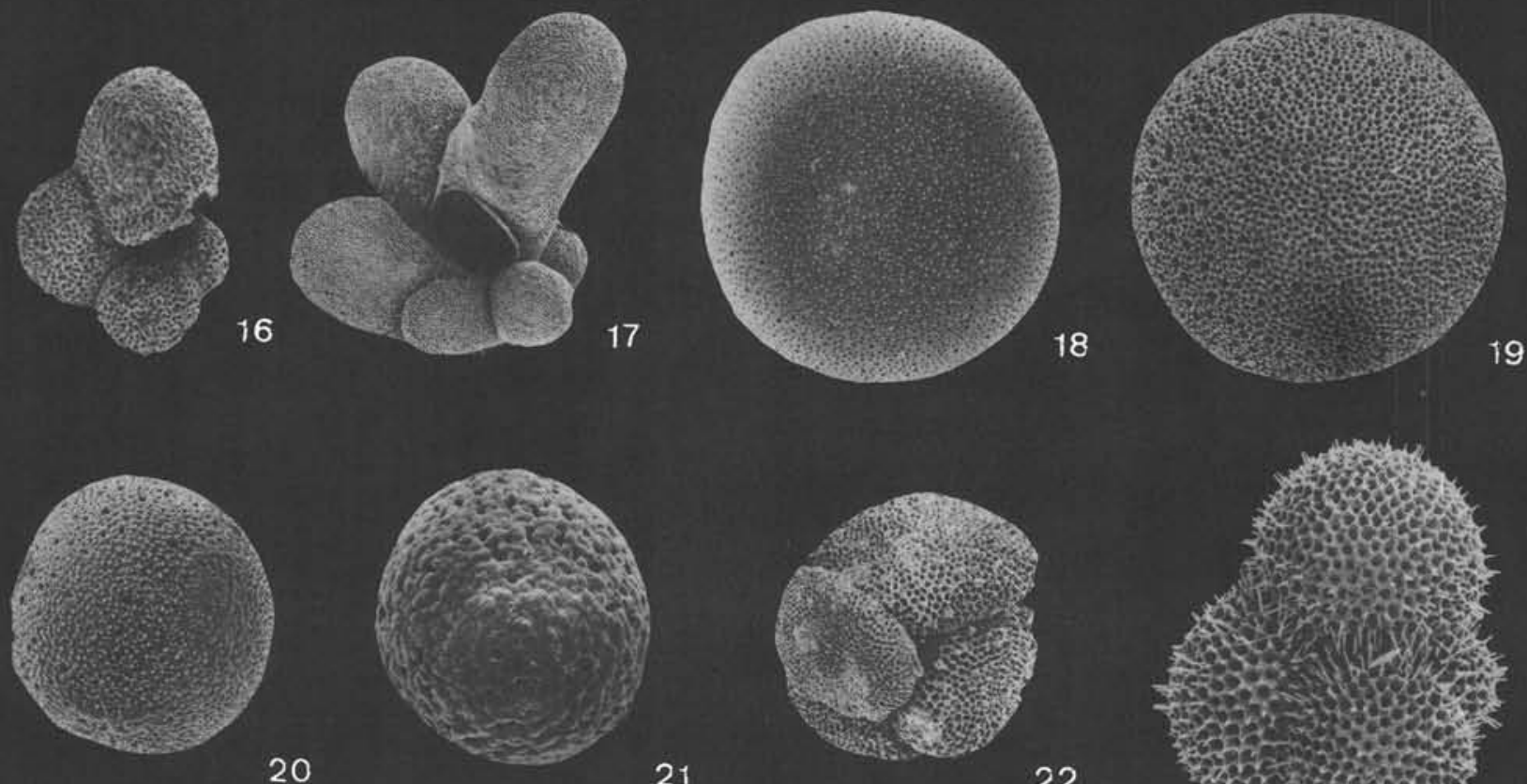

21

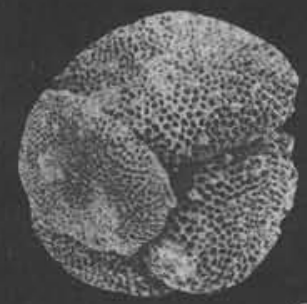

22

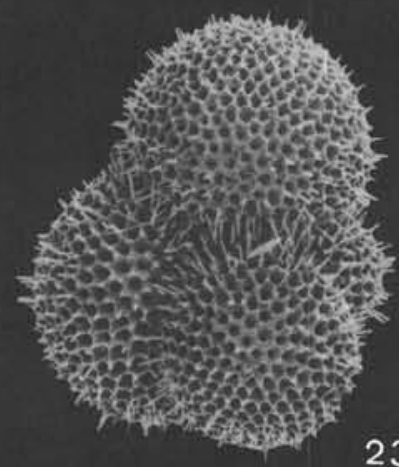




\section{PLATE 5}

Figures 1-5 Globigerinoides ruber ruber (d'Orb.). From Site 147, Core 2, Section 1 (top). Globorotalia fimbriata Subzone; Holocene. Figure 1: 100X; Figures 2 through 5: 50X.

Figure 1: Umbilical view, juvenile specimen (NMB C-26999). Figure 2: Umbilical view (NMB C-26998). Figure 3: Spiral view (NMB C-26997). Figure 4: Side view (NMB C-26996); see Plate 14, Figures 7 - 9. Figure 5: Side view (NMB C-26995).

Figure 6 Globigerinoides cf. ruber pyramidalis (Van den Broeck); side view (NMB C-26990); see Plate 14, Figure 10. From Site 147, Core 2, Section 1 (top). Globorotalia fimbriata Subzone; Holocene. 100X.

Figures 7-9 Globigerinoides ruber pyramidalis (Van den Broeck). From Site 147, Core 2, Section 1 (top). Globorotalia fimbriata Subzone; Holocene. All Figures (7 through 9): 50X.

Figure 7: Umbilical view (NMB C-26991). Figure 8: Spiral view (NMB C-26992). Figure 9: Side view (NMB C-26993); see Plate 14, Figure 11.

Figure 10 Globigerinoides ruber ruber (d'Orb.); spiral view (NMB C-26994). From Site 147, Core 2, Section 1 (top). Globorotalia fimbriata Subzone; Holocene. 50X.

Figure $11 \quad$ Globigerinoides ruber elongatus (d'Orb.); umbilical view (NMB C-27122); see Plate 74, Figure 12. From Site 147, Core 2, Section 4 (70-72 cm). Globigerina bermudezi Subzone; Late Pleistocene. 50X.

Figure 12 Globigerinoides ruber elongatus (d'Orb.); side view (NMB C-27123). From Site 147, Core 9, Section 1 $(146-148 \mathrm{~cm})$. Globorotalia hessi Subzone; Pleistocene. 50X.

Figures 13-15 Globigerinoides trilobus sacculifer (Brady). From Site 147, Core 2, Section 1 (top). Globorotalia fimbriata Subzone, Holocene. All figures (13 through 15): 50X.

Figure 13: Umbilical view (NMB C-27077). Figure 14: Umbilical view (NMB C-27080). Figure 15: Spiral view (NMB C-27079).

Figures 16-17 Globigerinoides tenellus Parker. From Site 147, Core 2, Section 4, (70-72 cm). Globigerina bermudezi Subzone; Late Pleistocene. Both figures (16 and 17): 100X.

Figure 16: Umbilical view (NMB C-27124); see Plate 13, Figure 12. Figure 17: Spiral view (NMB C-27125).

Figure 18 Globigerinoides tenellus Parker; side view, high spired specimen (NMB C-27126). From Site 147, Core 12, Section $4(43-45 \mathrm{~cm})$. Globorotalia hessi Subzone; Pleistocene. 100X.

Figures 19-20 Globigerinoides sp. From Site 147, Core 13, Section 5 (74-76 cm). Globorotalia hessi Subzone; Pleistocene. Both figures (19 and 20): $75 \times$.

Figure 19: Umbilical view (NMB C-27127). Figure 20: Spiral view (NMB C-27128).

Figures 21-23 Globigerinita glutinata (Egger). From Site 147, Core 2, Section 1, (top). Globorotalia fimbriata Subzone; Holocene. All Figures (21 through 23): 150X.

Figure 21: Umbilical view (NMB C-27013); see Plate 15, Figure 4. Figure 22: Umbilical view (NMB C-27014). Figure 23: Spiral view (NMB C-27015); see Plate 15, Figure 5.

Figure $24 \quad$ Globigerinita uvula uvula (Ehrenberg); side view (NMB C-27130); see Plate 15, Figure 7. From Site 147, Core 2, Section 3, (5-7 cm). Globigerina bermudezi Subzone; Late Pleistocene. 250X.

Figure $25 \quad$ Globigerinita uvula cf. minuta (Natland); side view (NMB C-27131); see Plate 15, Figure 8. From Site 147, Core 2, Section 4 (70-72 cm). Globigerina bermudezi Subzone; Late Pleistocene. $200 X$. 


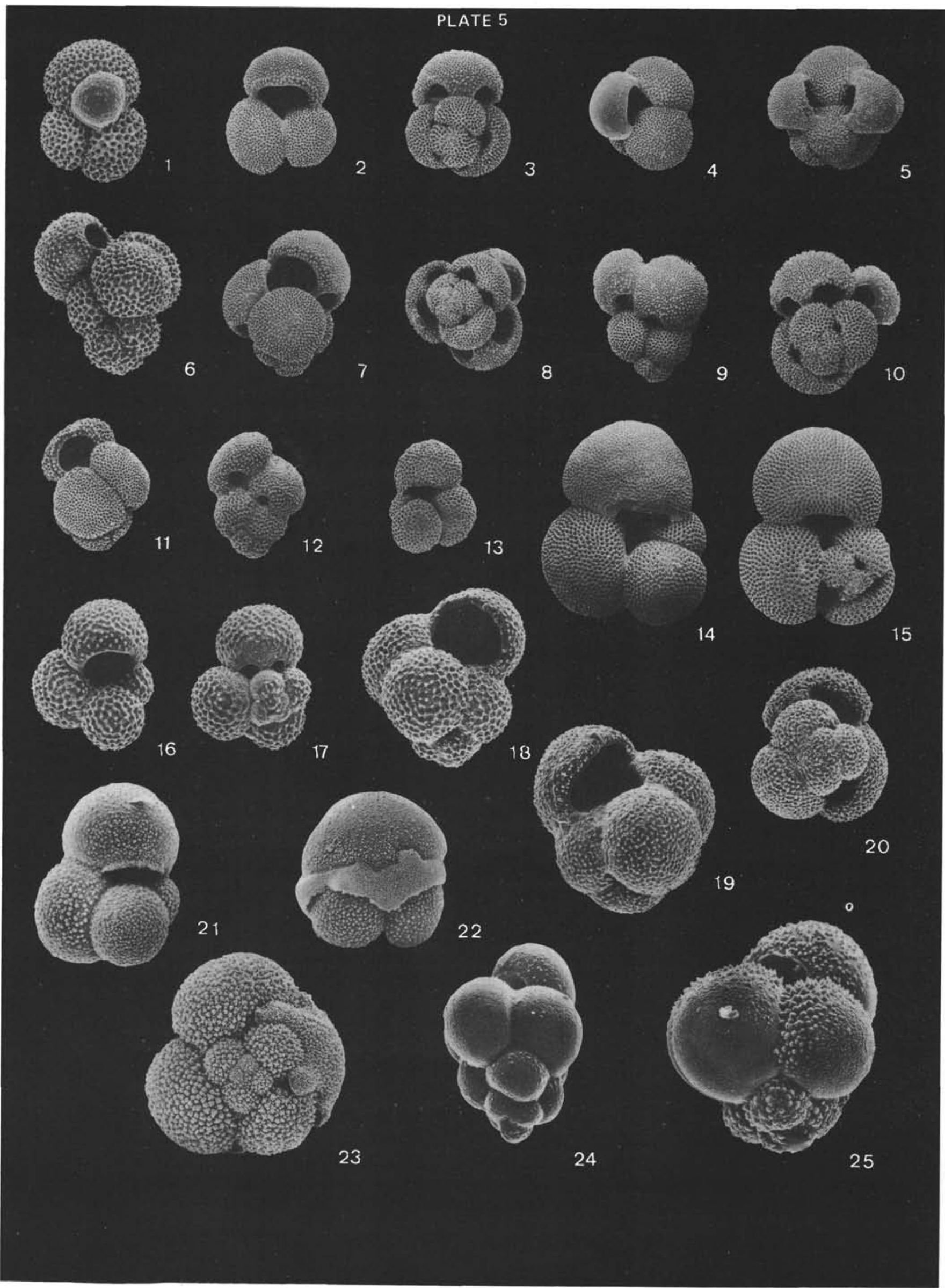




\section{PLATE 6}

Figures 1-2 Globorotalia cultrata (d'Orb.). From Site 147, Core 2, Section 1 (top). Globorotalia fimbriata Subzone; Holocene. Both figures (1 and 2): $37.5 \times$.

Figure 1: Spiral view (NMB C-27033). Figure 2: Umbilical view (NMB C-27034.

Figures 3-4 Globorotalia menardii (Parker, Jones and Brady). From Site 147, Core 15, Section 1, (18-20 cm). Globorotalia hessi Subzone; Pleistocene. Both figures (3 and 4): $75 \times$.

Figure 3: Spiral view (NMB C-27204). Figure 4: Umbilical view (NMB C-27203).

Figures 5-7 Globorotalia ungulata Bermudez. From Site 147, Core 2, Section 1 (top). Globorotalia fimbriata Subzone: Holocene. Figures 5 and 7; 50X, Figure 6: $37.5 \times$.

Figure 5: Spiral view (NMB C-27032). Figure 6: Umbilical view (NMB C-27035). Figure 7: Side view (NMB C-27031).

Figure $8 \quad$ Globorotalia truncatulinoides truncatulinoides (d'Orb.); umbilical view (NMB C-27010). From Site 147, Core 2, Section 1 (top). Globorotalia fimbriata Subzone; Holocene. $90 \times$.

Figure 9 Globorotalia tumida flexuosa (Koch); umbilical view (NMB C-27202). From Site 147, Core 6, Section 1 (top). Globigerina calida calida Subzone; Pleistocene. 50X.

Figures 10-11 Globorotalia tumida tumida (Brady). From Site 147, Core 11, (core catcher). Globorotalia hessi Subzone: Pleistocene. Both figures (10 and 11): $50 \mathrm{X}$.

Figure 10: Umbilical view (NMB C-27205). Figure 11: Side view (NMB C-27206).

Figure 12 Globorotalia truncatulinoides truncatulinoides (d'Orb.). Umbilical view, thick walled specimen (NMB C-27185). From Site 147, Core 18, Section 2, (75-77 cm). Globorotalia hessi Subzone; Pleistocene. $90 \mathrm{X}$.

Figures 13-15 Globorotalia scitula scitula (Brady). From Site 147, Core 18 (core catcher). Globorotalia hessi Subzone; Pleistocene. All figures (13 through 15): $100 \mathrm{X}$.

Figure 13: Umbilical view (NMB C-27174); see Plate 16, Figure 5. Figure 14: Side view (NMB C-27176). Figure 15: Spiral view (NMB C-27175).

Figures 16-20 Globorotalia bermudezi Rogl and Bolli, n. sp. From Site 147, Core 2, Section 1 (top). Globorotalia fimbriata Subzone; Holocene. All figures (16 through 20): 150X.

Figure 16: Spiral view (NMB C-27086); see Plate 16, Figure 1. Figure 17: Umbilical view (NMB C-27087); holotype; see Plate 16, Figure 2-3. Figure 18: Side view (NMB C-27088). Figure 19: Umbilical view (NMB C-27092). Figure 20: Spiral view (NMB C-27095). 


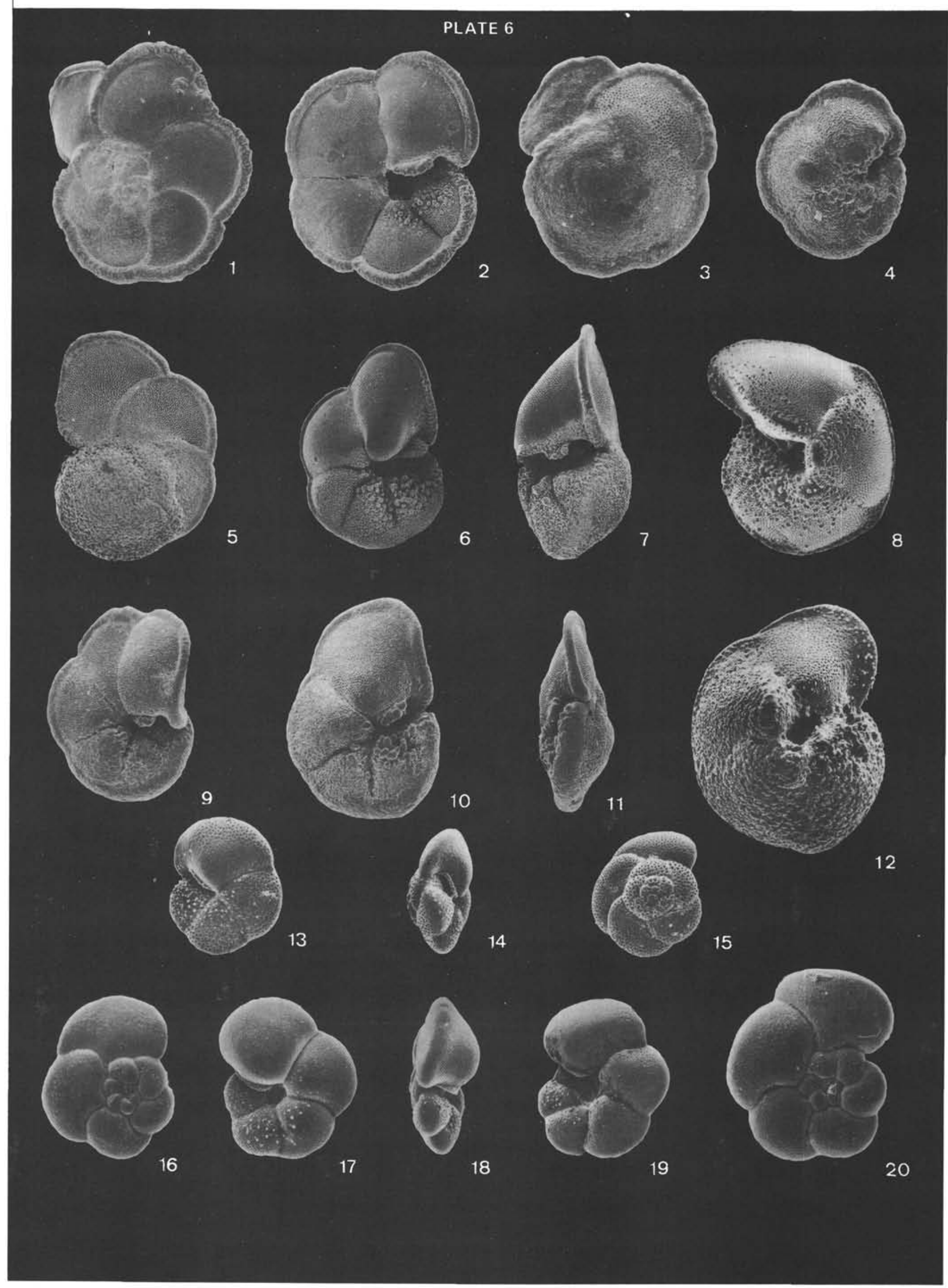




\section{PLATE 7}

Figures 1-4 Globorotalia sp. From Site 147, Core 2, Section 1 (top). Globorotalia fimbriata Subzone; Holocene. All Figures (1 through 4): 100X.

Figure 1: Umbilical view (NMB C-27039). Figure 2: Umbilical view (NMB C-27041). Figure 3: Side view (NMB C-27038). Figure 4: Spiral view (NMB C-27040); see Plate 16, Figure 4.

Figures 5-6 Globorotalia cavenula Be. From Site 147, Core 2, Section 1 (top). Globorotalia fimbriata Subzone; Holocene. Both figures (5 and 6): $100 \times$.

Figure 5: Umbilical view (NMB C-27036). Figure 6: Side view (NMB C-27037).

Figures 7-8 Globorotalia crassaformis crassaformis (Galloway and Wissler). From Site 147, Core 2, Section 1 (top).Globorotalia fimbriata Subzone; Holocene. Both figures ( 7 and 8$): 100 X$.

Figure 7: Umbilical view (NMB C-27008). Figure 8: Side view (NMB C-27007).

Figure 9 Globorotalia crassaformis crassaformis (Galloway and Wissler); umbilical view (NMB C-27183). From Site 147, Core 17, Section 5 (71-73 $\mathrm{cm})$. Globorotalia hessi Subzone; Pleistocene. 90X.

Figure 10 Globorotalia crassaformis crassaformis (Galloway and Wissler); side view (NMB C-27184). From Site 147, Core 17, Section 6 (76-78 cm). Globorotalia hessi Subzone; Pleistocene. 90X.

Figures 11-13 Globorotalia crassformis crassaformis (Galloway and Wissler). From Site 147, Core 2, Section 1 (top). Globorotalia fimbriata Subzone, Holocene. Figure 11: 90X; Figures 12 and 13: 100X.

Figure 11: Umbilical view (NMB C-27006); see Plate 16, Figure 8. Figure 12: Side view (NMB C-27002). Figure 13: Spiral view (NMB C-27001); see Plate 16, Figure 7.

Figure 14 Globorotalia crassaformis crassaformis (Galloway and Wissler); umbilical view, thick walled specimen (NMB C-27191). From Site 147, Core 4 (core catcher). Globigerina bermudezi Subzone; Late Pleistocene. $100 x$.

Figures 15-16 Globorotalia inflata (d'Orb.). From Site 147, Core 4, Section 5 (19-21 $\mathrm{cm})$. Globigerina bermudezi Subzone; Late Pleistocene. Both figures (15 and 16): 100X.

Figure 15: Umbilical view (NMB C-27186). Figure 16: Side view (NMB C-27188).

Figures 17-19 Globorotalia inflata (d'Orb.). From Site 147, Core 17, Section 5 (71-73 $\mathrm{cm})$. Globorotalia hessi Subzone; Pleistocene. All figures (17-19): $100 \times$.

Figure 17: Umbilical view (NMB C-27190). Figure 18: Side view (NMB C-27189). Figure 19: Spiral view (NMB C-27194).

Figures 20-21 Globorotalia inflata (d'Orb.). From Site 147, Core 4, Section 5 (19-21 $\mathrm{cm})$. Globigerina bermudezi Subzone; Late Pleistocene. Figure 20: 100X; Figure 21: $90 \mathrm{X}$.

Figure 20: Umbilical view (NMB C-27187). Figure 21: Spiral view (NMB C-27193); see Plate 16, Figure 6.

Figure 22 Globorotalia inflata (d'Orb.); umbilical view, small specimen (NMB C-27213). From Site 147, Core 2, Section $3(99-101 \mathrm{~cm})$. Globigerina bermudezi Subzone; Late Pleistocene. 150X. 


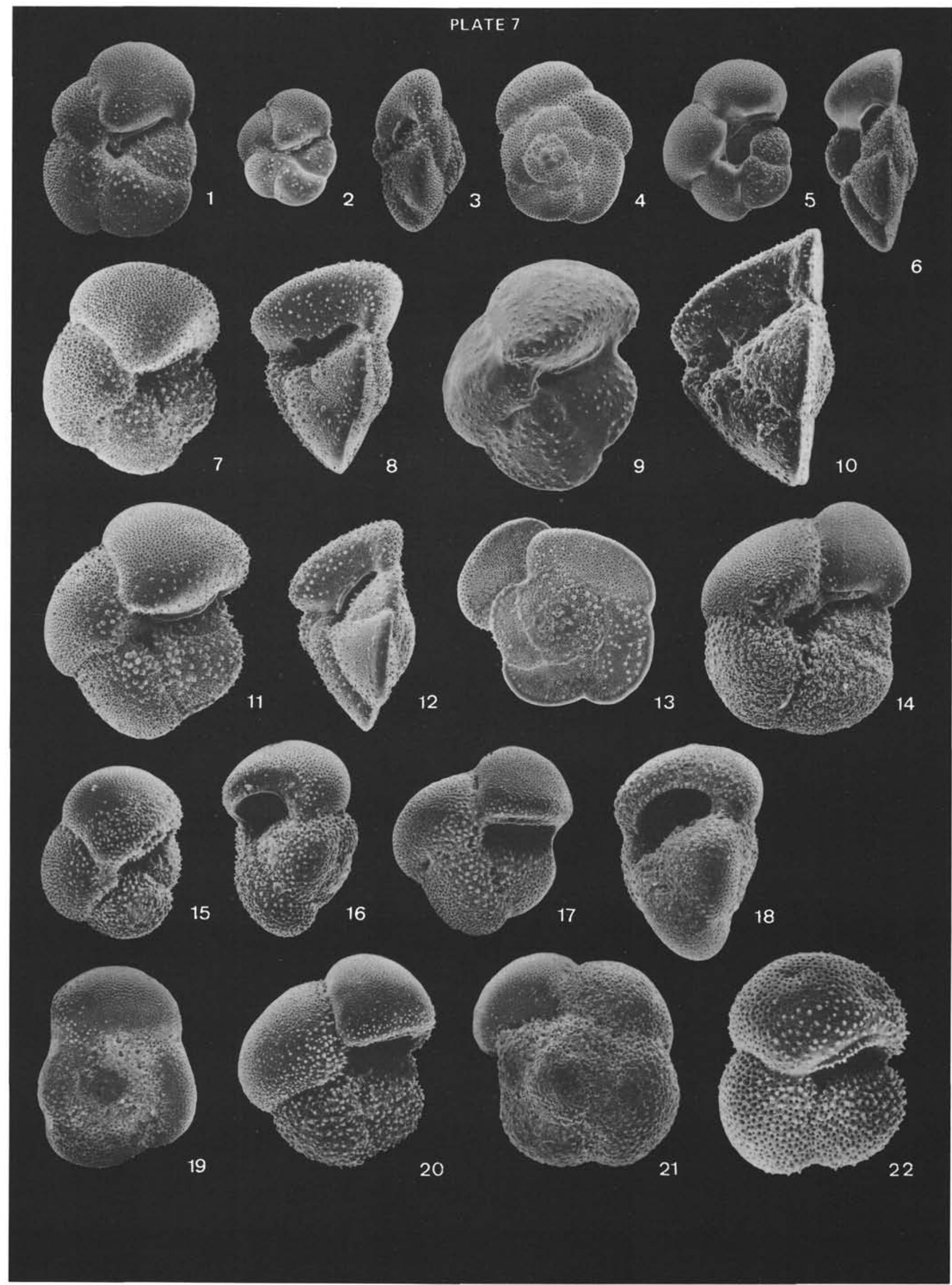




\section{PLATE 8}

Figure 1 Turborotalita anfracta (Parker); umbilical view (NMB C-27167). From Site 147, Core 6 (core catcher). Globigerina calida calida Subzone; Pleistocene. 250X.

Figures 2-4 Turborotalita anfracta (Parker). From Site 147, Core 2, Section 1 (top). Globorotalia fimbriata Subzone; Holocene. All figures (2 through 4): $150 \times$.

Figure 2: Umbilical view (NMB C-27102), see Plate 15, Figure 10. Figure 3: Side view (NMB C-27103). Figure 4: Spiral view (NMB C-27104).

Figures 5-7 Turborotalia anfracta (Parker). From Site 147, Core 6 (core catcher). Globigerina calida calida Subzone; Pleistocene. All figures (5 through 7): $150 \times$.

Figure 5: Umbilical view (NMB C-27166). Figure 6: Side view (NMB C-27169). Figure 7: Spiral view (NMB C-27168).

Figures 8-12 Turborotalita sp., small form. From Site 147, Core 2, Section 1 (top). Globorotalia fimbriata Subzone; Holocene. All figures (8 through 12): $150 \times$.

Figure 8: Umbilical view (NMB C-27101). Figure 9: Spiral view (NMB C-27100). Figure 10: Side view (NMB C-27099). Figure 11: Umbilical view (NMB C-27096). Figure 12: Spiral view (NMB C-27097); see Plate 15 , Figure 11.

Figures 13-14 Turborotalita sp., large form. From Site 147, Core 3, Section 1 (100-102 cm). Globigerina bermudezi Subzone; Late Pleistocene. Both figures (13 and 14): $150 \mathrm{X}$.

Figure 13: Umbilical view (NMB C-27150); see Plate 15, Figure 12. Figure 14: Spiral view (NMB C-27151).

Figures 15-16 Pulleniatina obliquiloculata obliquiloculata (Parker and Jones). From Site 147, Core 2, Section 1 (top). Globorotalia fimbriata Subzone; Holocene. Both figures (15 and 16): 100X.

Figure 15: Umbilical view (NMB C-27011). Figure 16: Umbilical view, specimen with thick cortex (NMB C-27012).

Figures 17-20 Turborotalita (Parker). From Site 147, Core 2, Section 1 (top). Globorotalita fimbriata Subzone; Holocene. All figures (17 through 20): $150 X$.

Figure 17: Umbilical view (NMB C-27108). Figure 18: Side view (NMB C-27109). Figure 19: Umbilical view, specimen with bulla (NMB C-27111). Figure 20: Spiral view (NMB C-27110).

Figures 21-23 Turborotalita iota (Parker), large specimens. From Site 147, Core 2, Section $4(2-4 \mathrm{~cm})$. Globigerina bermudezi Subzone; Late Pleistocene. All figures (21 through 23): 150X.

Figure 21: Umbilical view, specimen with bulla (NMB C-27135). Figure 22: Umbilical view (NMB C-27136); see Plate 16, Figure 9. Figure 23: Spiral view, specimen with bulla (NMB C-27137). 


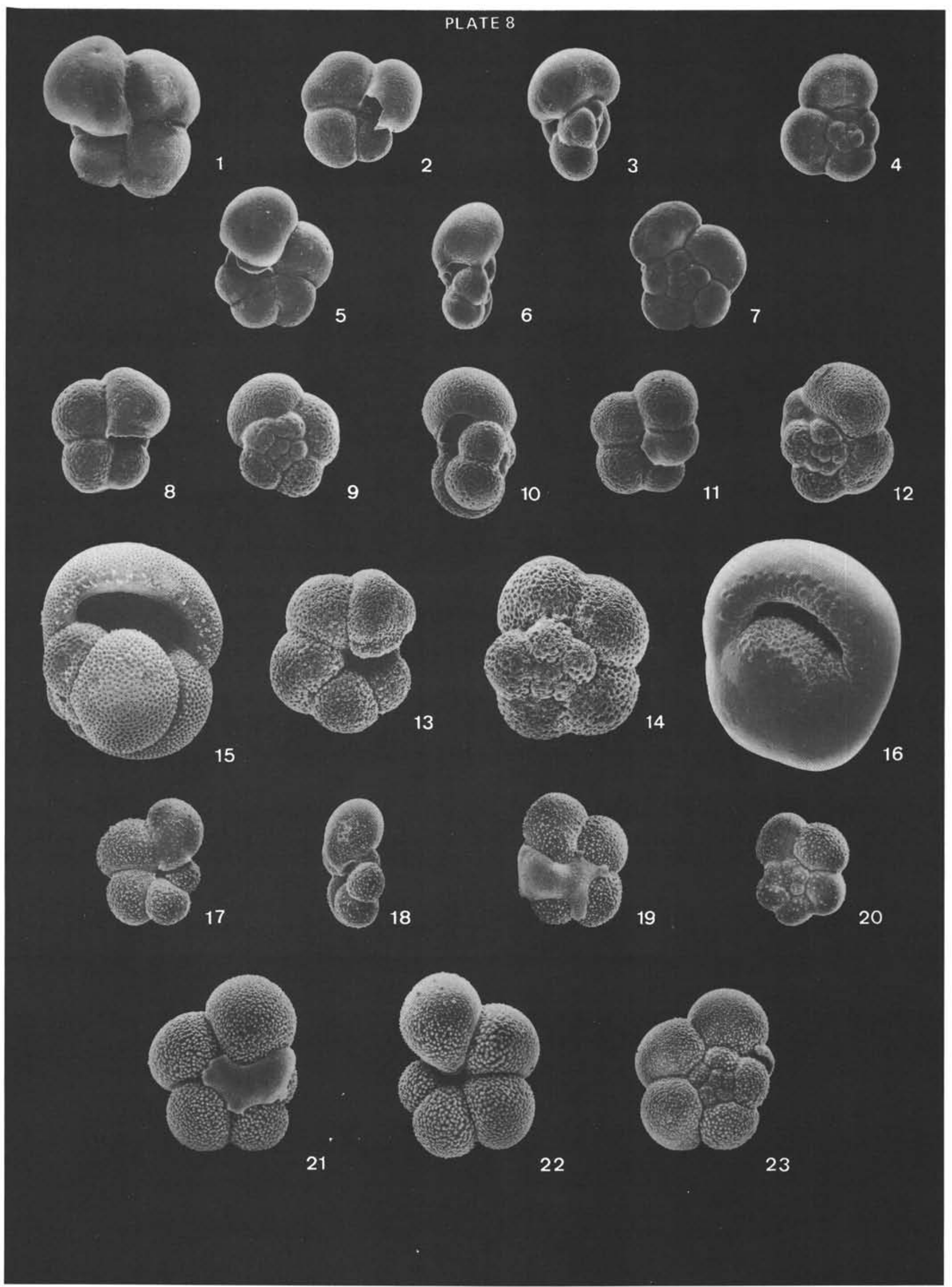




\section{PLATE 9}

All Figures are $75 X$

Figures 1-5 Neogloboquadrina dutertrei dutertrei (d'Orb.). From Site 147, Core 2, Section 1 (top). Globorotalia fimbriata Subzone; Holocene.

Figure 1: Umbilical view, juvenile specimen (NMB C-27075). Figure 2: Umbilical view, juvenile specimen (NMB C-27071). Figure 3: Umbilical view, thick walled small specimen (NMB C-27076). Figure 4: Umbilical view, juvenile specimen (NMB C-27074). Figure 5: Umbilical view (NMB C-27052); see Plate 17, Figures 2-3.

Figure 6 Neogloboquadrina dutertrei dutertrei (d'Orb.); umbilical view, small multichambered specimen (NMB C-27144). From Site 147, Core 9, Section 4 (50-52 cm). Globorotalia hessi Subzone; Pleistocene.

Figures 7-9 Neogloboquadrina dutertrei dutertrei (d'Orb.). From Site 147, Core 2, Section 1 (top). Globorotalia fimbriata Subzone; Holocene.

Figure 7: Umbilical view (NMB C-27071). Figure 8: Umbilical view (NMB C-27053); see Plate 17, Figures 1 and 4. Figure 9: Umbilical view (NMB C-27054); see Plate 17, Figures 5-6.

Figures 10-12 Neogloboquadrina dutertrei ssp. Samples for 10 and 12 are from Site 147, Core 17, Section $5(71-73 \mathrm{~cm})$; sample for 11 is from Site 147 , Core 17, Section $4(8-10 \mathrm{~cm})$. Globorotalia hessi Subzone; Pleistocene. Figure 10: Umbilical view, with bulla (NMB C-27179); see Plate 17, Figure 11. Figure 11: Umbilical view, specimen with bulla (NMB C-27180); see Plate 17, Figure 10. Figure 12: Spiral view, specimen without bulla (NMB C-27178).

Figures 13-16 Neogloboquadrina dutertrei pseudopima (Blow). From Site 147, Core 2, Section 1 (top). Globorotalia fimbriata Subzone; Holocene.

Figure 13: Umbilical view (NMB C-27058); see Plate 17, Figure 7.

Figure 14: Spiral view (NMB C-27057). Figure 15: Umbilical view (NMB C-27055); see Plate 17, Figures 8-9. Figure 16: Side view (NMB C-27056).

Figures 17-18 Neogloboquadrina dutertrei pseudopima (Blow). From Site 147, Core 4 (core catcher). Globigerina bermudezi Subzone: Late Pleistocene.

Figure 17: Umbilical view (NMB C-27142). Figure 18: Side view (NMB C-27143).

Figures 19-20 Neogloboquadrina dutertrei blowi Rögl and Bolli, nom. nov. From Site 147, Core 9, Section 2 (119-121 cm). Globorotalia hessi Subzone; Pleistocene.

Figure 19: Umbilical view (NMB C-27141). Figure 20: Side view (NMB C-27140).

Figures 21-22 Neogloboquadrina dutertrei blowi Rögl and Bolli, nom. nov. From Site 147, Core 4 (core catcher). Globigerina bermudezi Subzone; Late Pleistocene.

Figure 21: Umbilical view (NMB C-27145), see Plate 17, Figure 12.

Figure 22: Side view (NMB C-27146). 


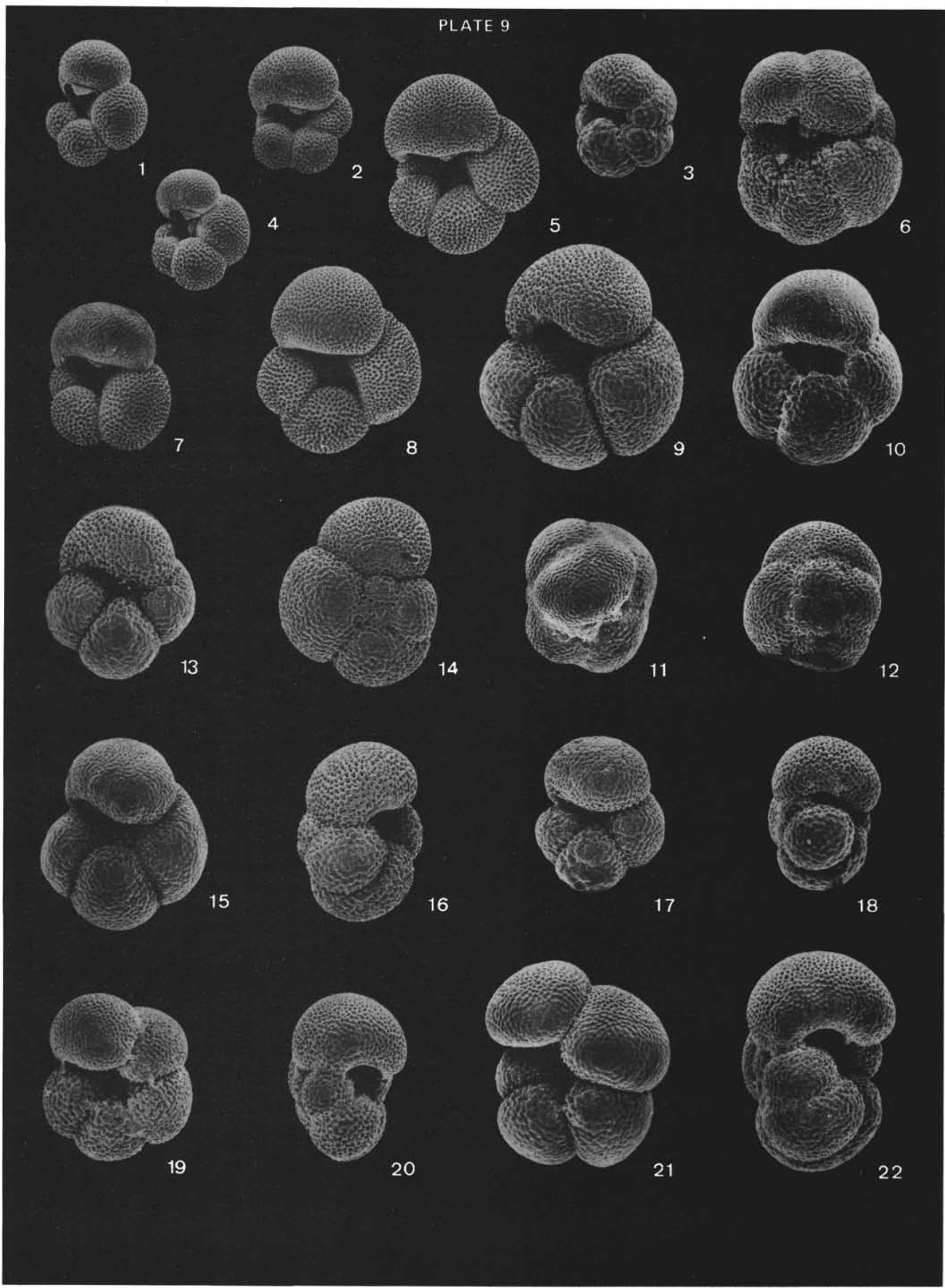


PLATE 10

Figures 1-8 Neogloboquadrina dutertrei dutertrei (d'Orb.). Samples for 1 through 3 and 6 through 8 are from Site 147, Core 2, Section 1 (top). Globorotalia fimbriata Subzone; Holocene. Samples for 4 and 5 are from Site 147, Core 4 (core catcher). Globigerina bermudezi Subzone; Late Pleistocene. Samples shown in 1 through 3 are five-chambered axially compressed specimens. Those shown in 4 through 5 are six-chambered and those in 6 through 8 have the last whorl higher coiled. All figures (1 through 8): $50 \times$.

Figure 1: Umbilical view (NMB C-27065). Figure 2: Spiral view (NMB C-27064). Figure 3: Side view (NMB C-27063). Figure 4: Umbilical view (NMB C-27148). Figure 5: Spiral view (NMB C-27147). Figure 6: Umbilical view (NMB C-27062). Figure 7: Spiral view (NMB C-27060). Figure 8: Side view (NMB C-27059).

Figures 9-10 Neogloboquadrina dutertrei dutertrei (d'Orb.); high spired specimens. From Site 147, Core 18 (core catcher). Globorotalia hessi Subzone: Pleistocene. Both figures ( 9 and 10): 50X.

Figure 9: Umbilical view (NMB C-27182). Figure 10: Side view (NMB C-27181).

Figures 11-16 Neogloboquadrina pachyderma incompta (Cifelli). Samples for 11 and 12 are from Site 147, Core 2, Section 3 $(5-7 \mathrm{~cm})$; samples for 13 and 14 are from Site 147, Core 2, Section $3(99-101 \mathrm{~cm})$; samples for 15 and 16 are from Site 147, Core 5, Section $2(114-116 \mathrm{~cm})$. Globigerina bermudezi Subzone; Late Pleistocene. All figures show typical rightcoiled specimens. All figures (11 through 16): 150X.

Figure 11: Umbilical view (NMB C-27152). Figure 12: Umbilical view (NMB C-27153). Figure 13: Umbilical view (NMB C-27207); see Plate 16, Figure 10. Figure 14: Spiral view (NMB C-27209). Figure 15: Umbilical view (NMB C-27155); see Plate 16, Figure 11. Figure 16: Side view (NMB C-27154).

Figures 17-20 Neogloboquadrina pachyderma incompta (Cifelli). Samples for 17, 19 and 20 are from Site 147, Core 9, Section $2(119-121 \mathrm{~cm})$; Globorotalia hessi Subzone; Pleistocene. Sample for 18 is from Site 147, Core 2, Section 3 (99-101 cm); Globigerina bermudezi Subzone; Late Pleistocene. All figures show large specimens with similarity to the $N$. dutertrei - group, especially by separation of the final chamber. Figure 17: 150X; Figures 18-20: 100X.

Figure 17: Umbilical view, specimen with separated final chamber (NMB C-27215). Figure 18: Umbilical view (NMB C-27212). Figure 19: Umbilical view (NMB C-27214). Figure 20: Side view (NMB C-27216).

Figures 21-22 Neogloboquadrina pachyderma incompta (Cifelli). From Site 147, Core 12, Section $6(121-123 \mathrm{~cm})$. Globorotalia hessi Subzone; Pleistocene. All figures show typical sinistrally coiled specimens. Both figures (21 and 22): $150 \mathrm{X}$.

Figure 21: Umbilical view (NMB C-27156). Figure 22: Umbilical view (NMB C-27157). 


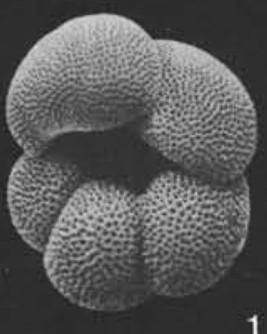

PLATE 10
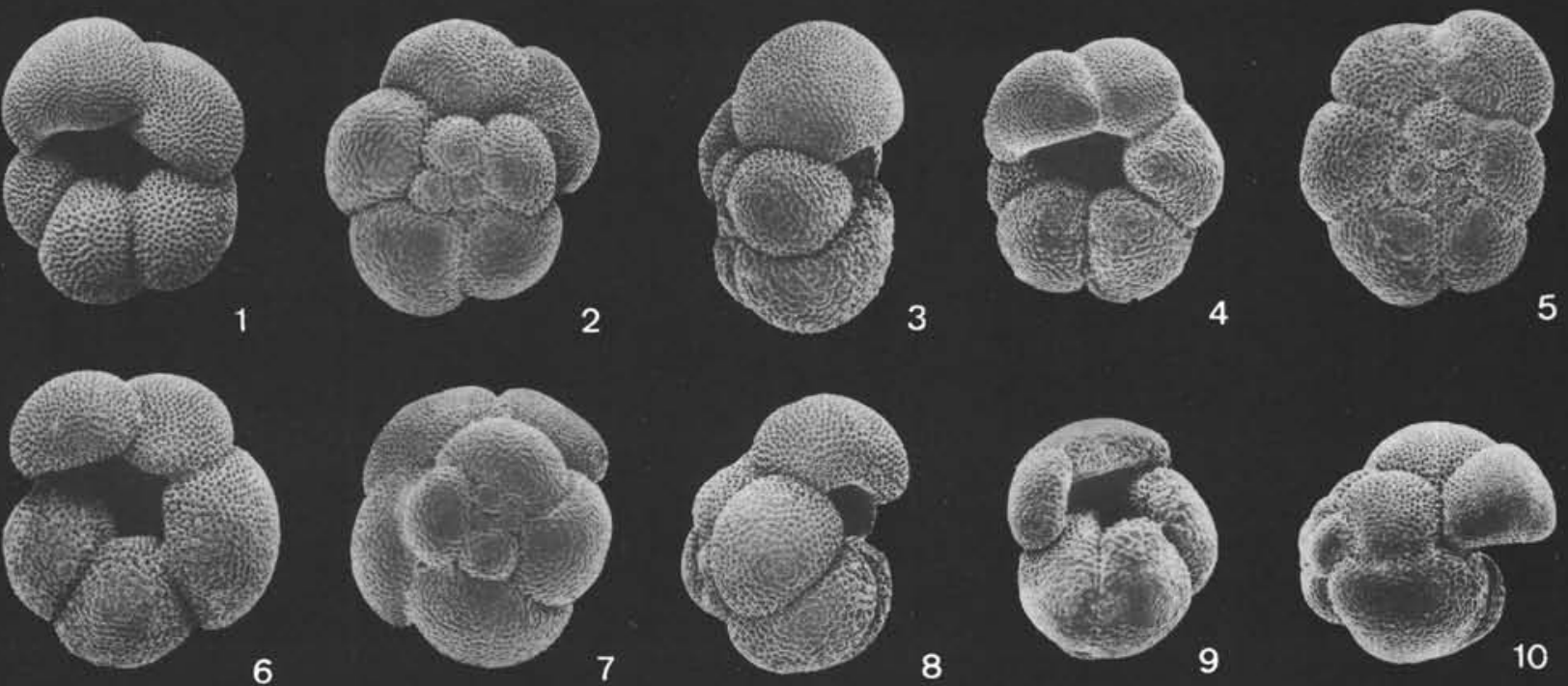

5

6
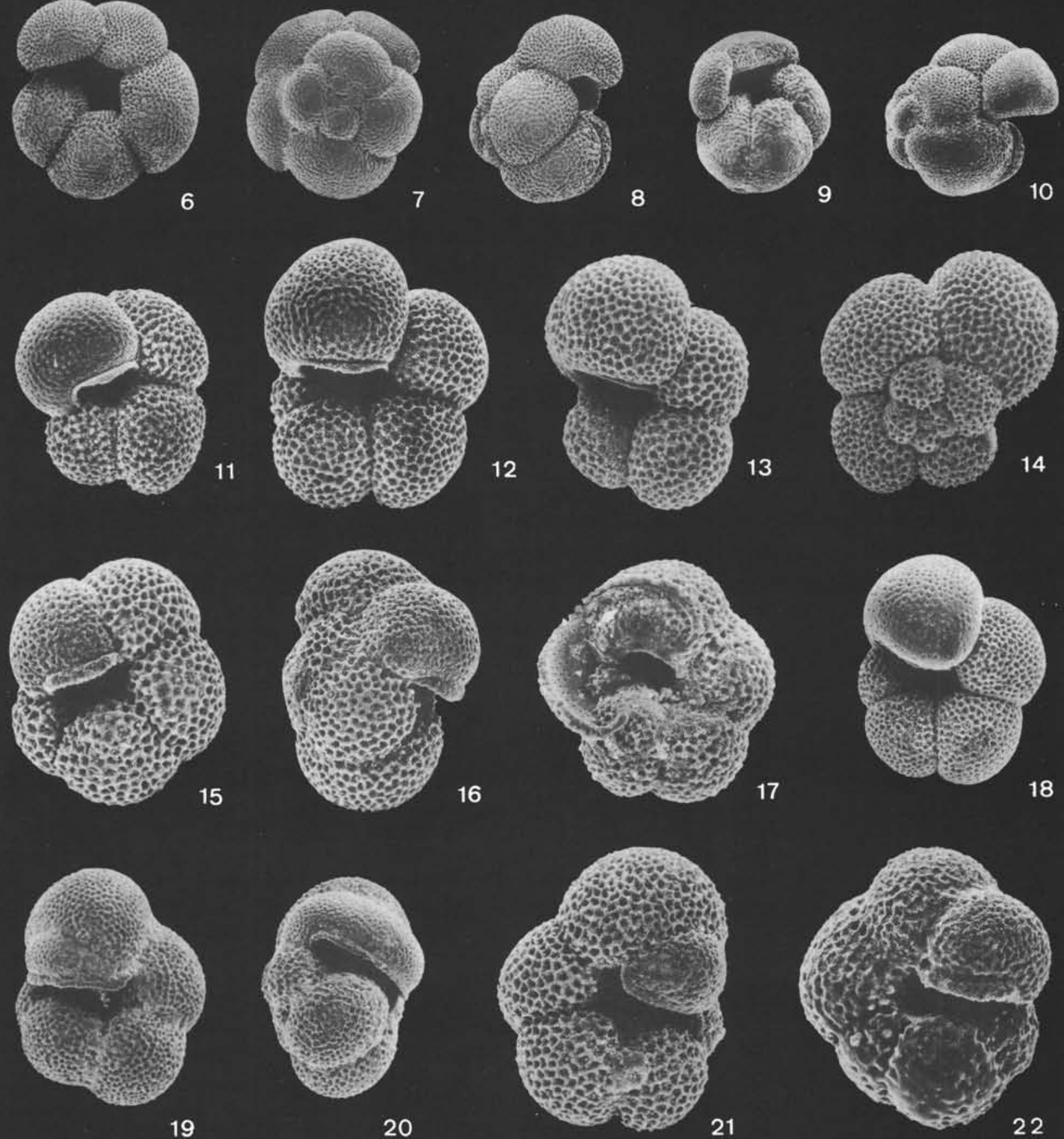


\section{PLATE 11}

Figure 1 Neogloboquadrina intermediate between pachyderma pachyderma and pachyderma incompta; umbilical view (NMB C-27177). From Site 147, Core 18 (core catcher). Globorotalia hessi Subzone; Pleistocene. $150 \times$.

Figures 2-6 Neogloboquadrina pachyderma pachyderma (Ehrenberg). From Site 147, Core 12, Section 6 (121-123 $\mathrm{cm})$. Globorotalia hessi Subzone; Pleistocene. All figures (2-6): 150X.

Figure 2: Umbilical view (NMB C-27218). Figure 3: Umbilical view (NMB C-27161). Figure 4: Umbilical view (NMB C-27160); see Plate 16, Figure 12. Figure 5: Umbilical view (NMB C-27158). Figure 6: Spiral view (NMB C-27159).

Figure $7 \quad$ Globigerina megastoma cariacoensis Rögl and Bolli, $\mathrm{n}$. ssp; side view, specimen with aberrant, bulla like final chamber (NMB C-26960); see Plate 11, Figure 10. From Site 147, Core 2, Section 1 (top). Globorotalia fimbriata Subzone; Holocene. 100X.

Figure $8 \quad$ Globigerina bulloides s.1.; umbilical view, specimen with bulla like chamber (NMB C-26945); see Plate 11, Figure 11. From Site 147, Core 2, Section 1 (top) Globorotalia fimbriata Subzone; Holocene. 100X.

Figure $9 \quad$ Globigerina bermudezi Seiglie; spiral view, specimen with bulla like chamber (NMB C-26973); see Plate 11, Figure 12. From Site 147, Core 2, Section 1 (top). Globorotalia fimbriata Subzone; Holocene. 75X.

Figure 10 Globigerina megastoma cariacoensis Rögl and Bolli, n. ssp. See Plate 11, Figure 7. 250X.

Figure $11 \quad$ Globigerina bulloides s.1. See Plate 11, Figure 8. $250 \mathrm{X}$.

Figure $12 \quad$ Globigerina bermudezi Seiglie. See Plate 11, Figure 9. $500 \mathrm{x}$.

Figure $13 \quad$ Globigerina bulloides umbilicata Orr and Zaitzeff. See Plate 1, Figure 24. 1000X.

Figure $14 \quad$ Globigerina sp. 1. See Plate 2, Figure 22. 1000X.

Figure 15 Globigerina sp. 2. See Plate 2, Figure 24. 1000X. 


\section{PLATE 11}
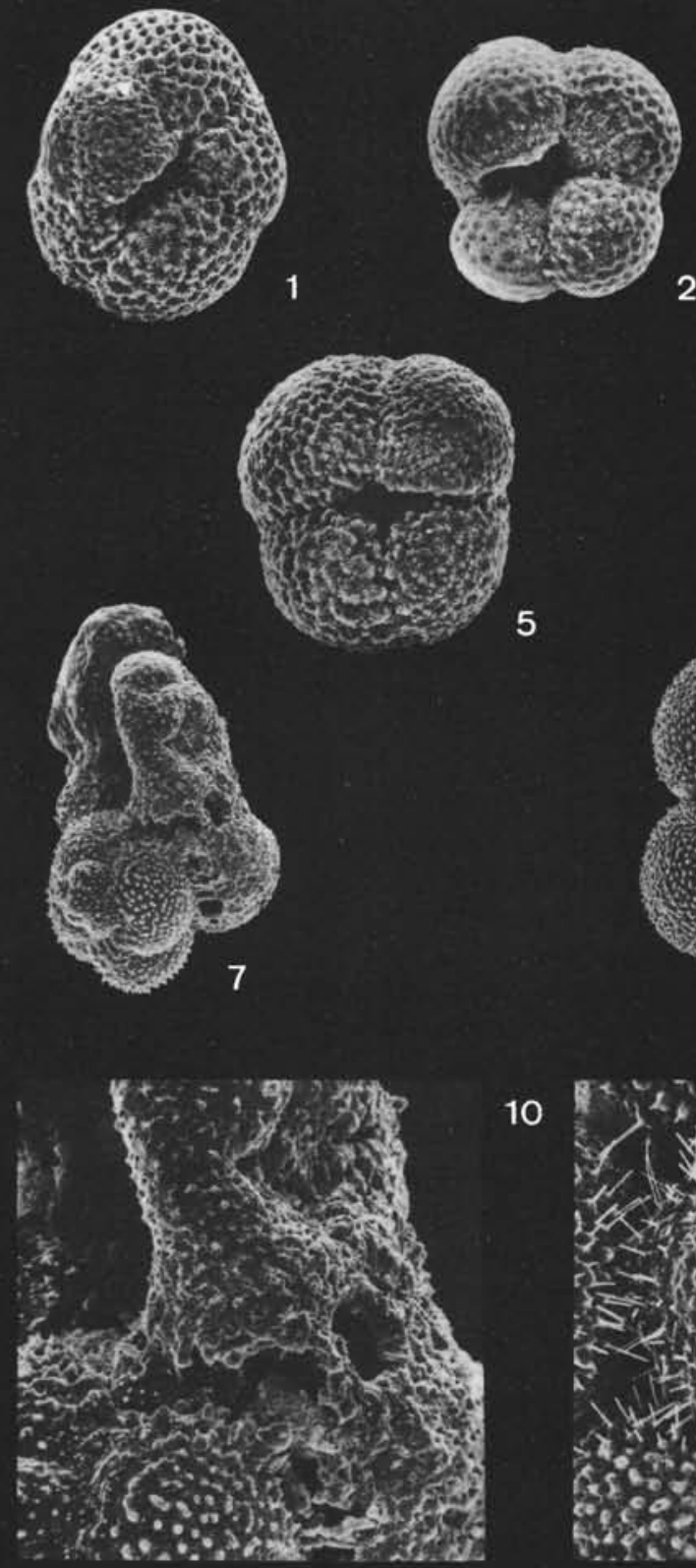

10
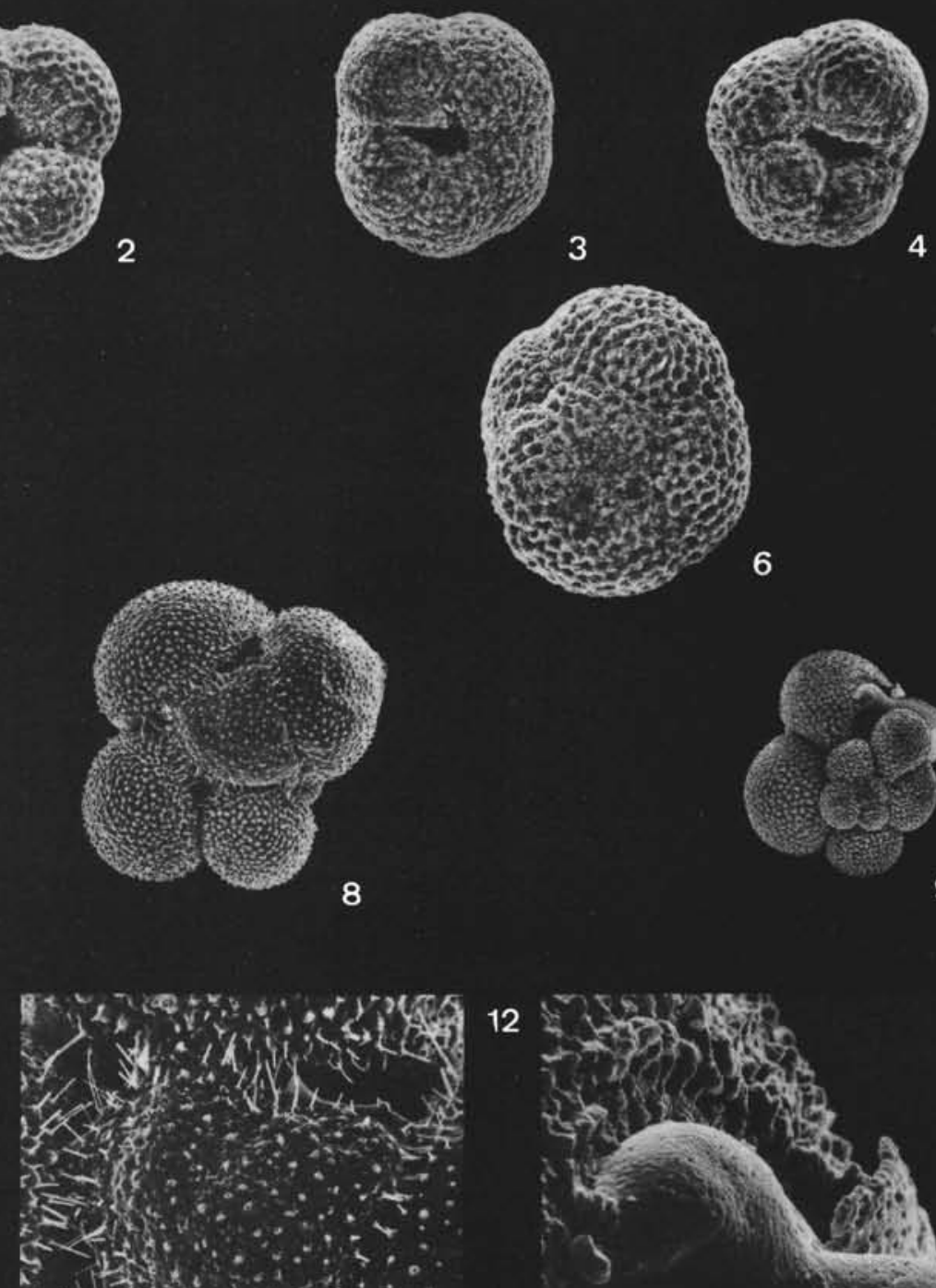

6

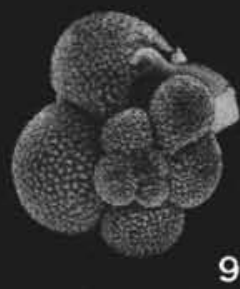

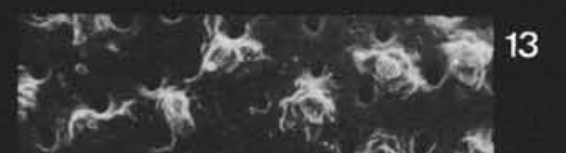

- 0 a a

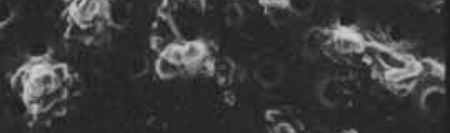

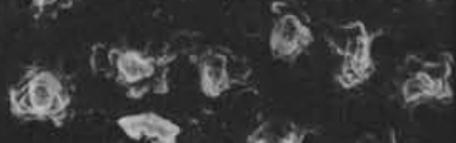

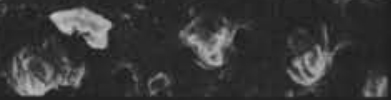

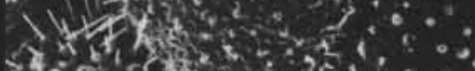

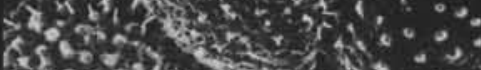

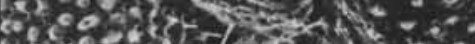

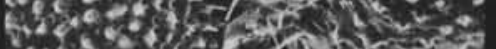

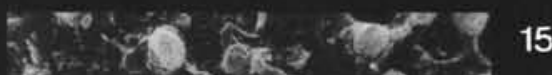
$8 \times(x-2)+20$ La $x \mathrm{~A}^{2}$. Iy 0 को

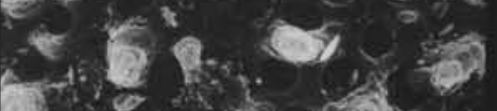

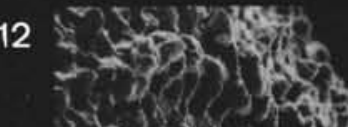

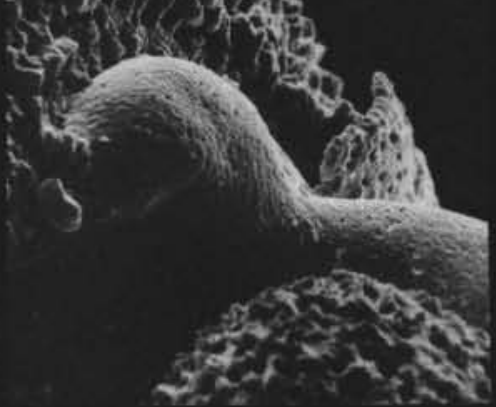

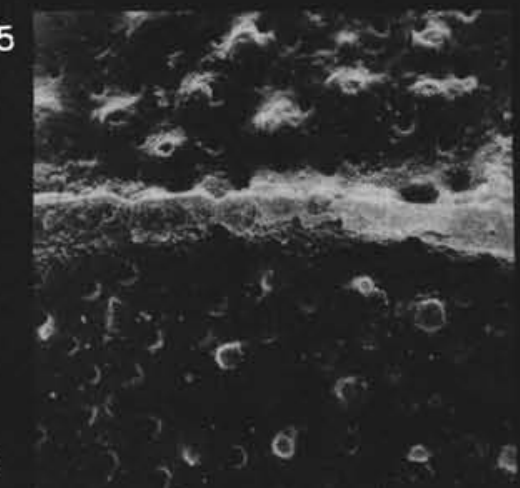




\section{PLATE 12}

Figure 1 Globigerina bulloides bulloides d'Orb.; final chamber. See Plate 1, Figure 11. 1000X.

Figure 2 Globigerina bulloides cf. quadrilatera Galloway and Wissler; penultimate chamber. See Plate 1, Figure 16. $1000 x$.

Figure 3 Globigerina bulloides cf. quadrilatera Galloway and Wissler; third last chamber. See Plate 1, Figure 16. 1000X.

Figure $4 \quad$ Globigerina bermudezi Seiglie; third last chamber. See Plate 2, Figure 15. 1000X.

Figure 5 Globigerina megastoma cariacoensis Rögl and Bolli n. ssp.; penultimate chamber. See Plate 2, Figure 7. 1000X.

Figure 6 Globigerina megastoma cariacoensis Rögl and Bolli, n. ssp.; penultimate chamber. See Plate 2, Figure 7. $5000 x$.

Figure $7 \quad$ Globigerina bulloides $\mathrm{cf}$. quadrilatera Galloway and Wissler; final chamber. See Plate 1, Figure 16.1000X.

Figure $8 \quad$ Globigerina bulloides bulloides d'Orb.; spiral side with secondary aperture. See Plate 1, Figure 3. 500X.

Figure 9 Globigerina calida calida Parker; penultimate chamber. See Plate 3, Figure 1.1000X.

Figure 10 Globigerina calida calida Parker; penultimate chamber. See Plate 3, Figure 3. 1000X.

Figure 11 Globigerina calida calida Parker; penultimate chamber. See Plate 3, Figure 8. 1000X.

Figure 12 Globigerina calida calida Parker; first chamber of the last whorl. See Plate 3, Figure 6. 1000X. 


\section{PLATE 12}

arivere 1. Q.

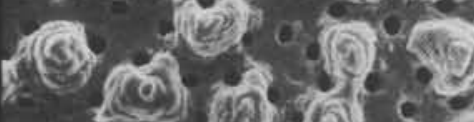
a) $\because$ (4)

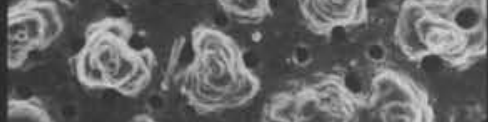

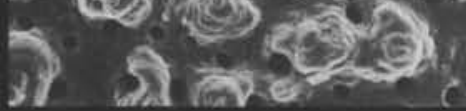
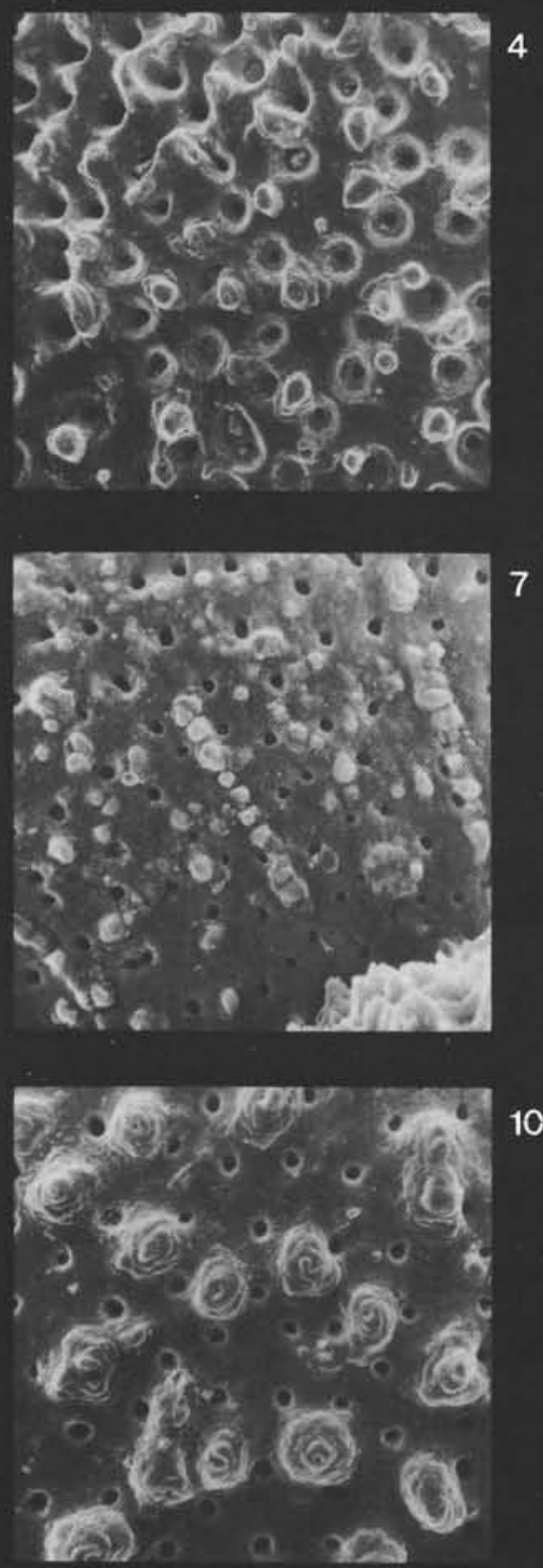
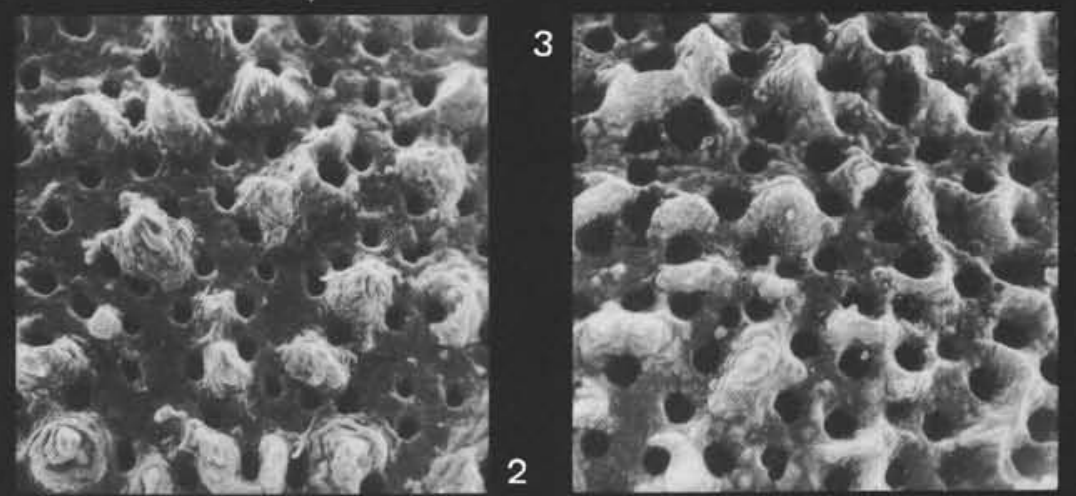

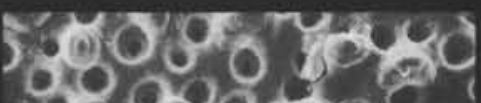

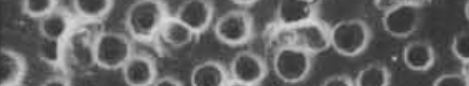

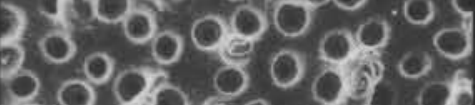
3. $01000 \%$

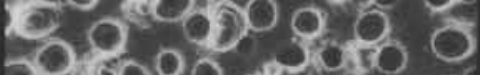

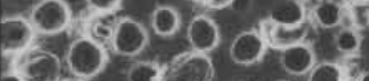

(3) 32010

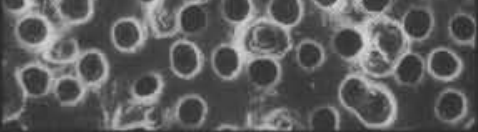

5
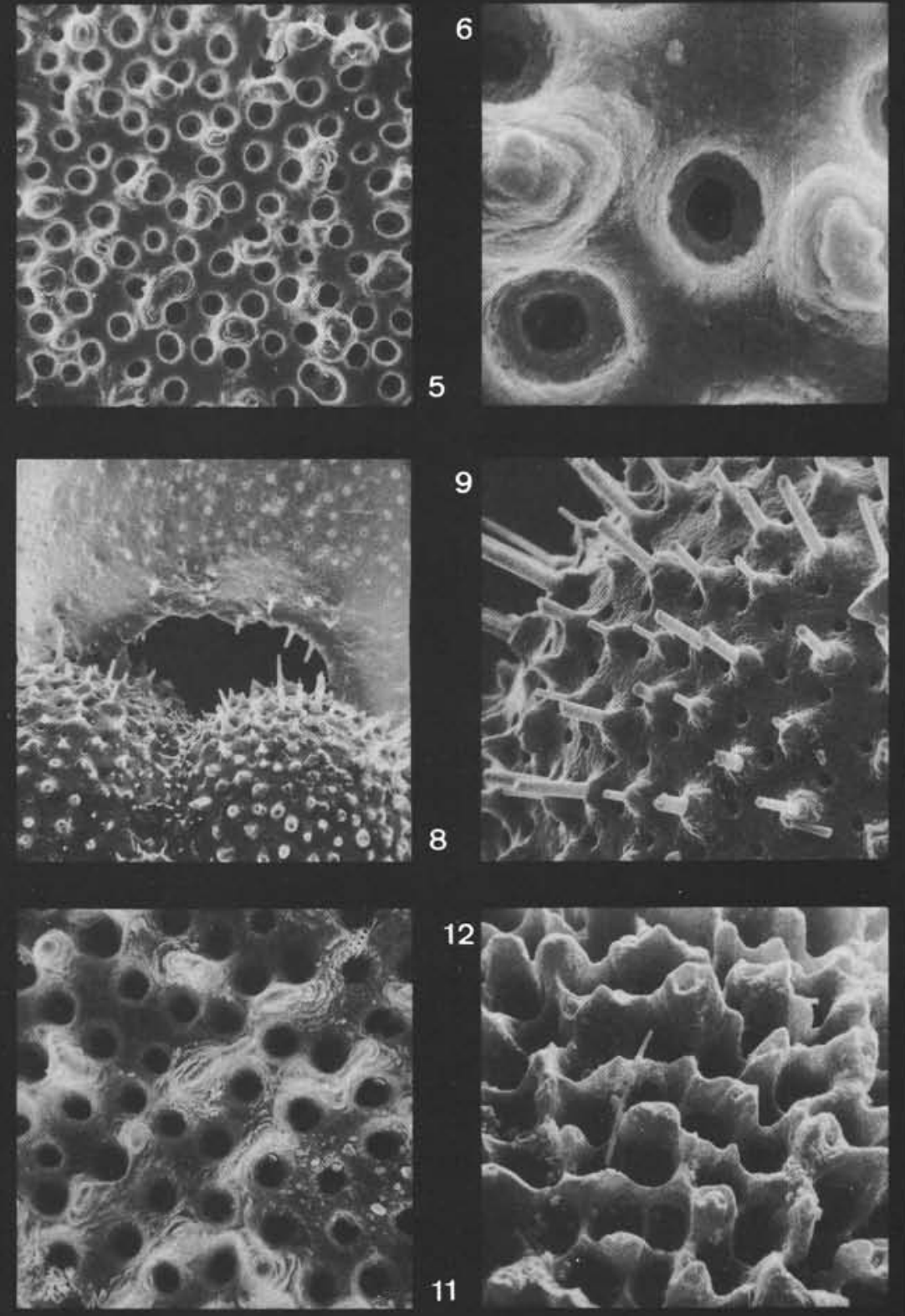


\section{PLATE 13}

Figure 1 Globigerina cf. falconensis Blow; final chamber. See Plate 2, Figure 20. 1000X.

Figure 2 Globigerina calida praecalida Blow; final chamber. See Plate 3, Figure 11. 1000X.

Figure 3 Globigerina rubescens Hofker; penultimate chamber. See Plate 4, Figure 8. 1000X.

Figure $4 \quad$ Globigerinella siphonifera siphonifera (d'Orb.); spiral side. See Plate 3, Figure 19. 500X.

Figure $5 \quad$ Globigerinella siphonifera involuta (Cushman); final chamber. See Plate 3, Figure 16. 1000X.

Figure 6 Hastigerinella digitata (Brady); penultimate chamber. See Plate 4, Figure 16. 1000X.

Figure $7 \quad$ Hastigerinella digitata (Brady); third last chamber. See Plate 4, Figure 17. 1850X.

Figure 8 Hastigerinella digitata (Brady); spines. See Plate 4, Figure 17. 10,750X.

Figure 9 Hastigerinella digitata (Brady); triradiate spine. See Plate 4, Figure 17. 11,000X.

Figure 10 Hastigerina pelagica (d'Orb.); younger part. See Plate 3 , Figure 21.250X.

Figure 11 Hastigerina pelagica (d'Orb.); older chamber. See Plate 3, Figure 23. 1000X.

Figure 12 Globigerinoides tenellus Parker; penultimate chamber. See Plate 5, Figure 16. 1000X. 


\section{PLATE 13}

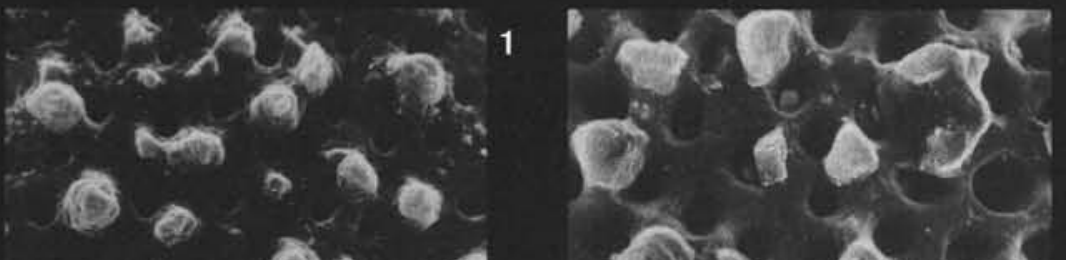
0000 . कर $\because: 00$

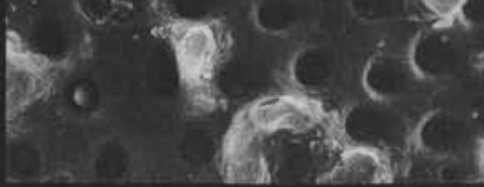

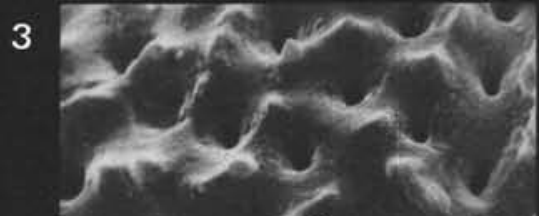

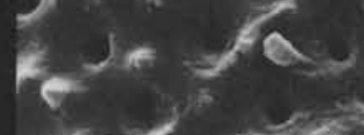

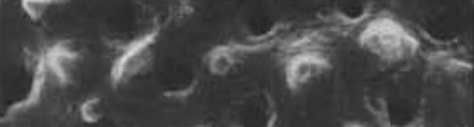

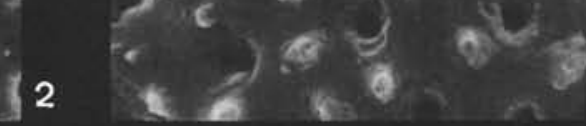

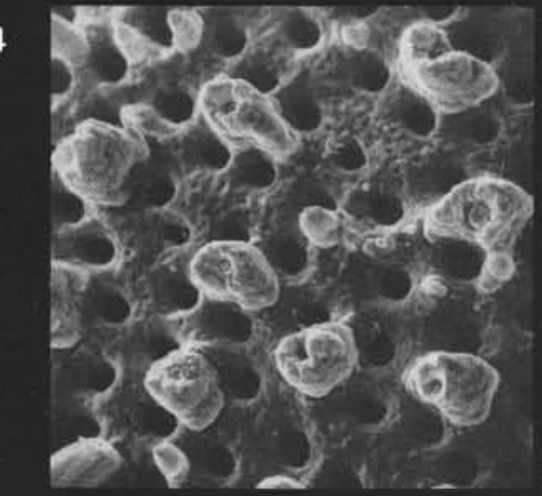

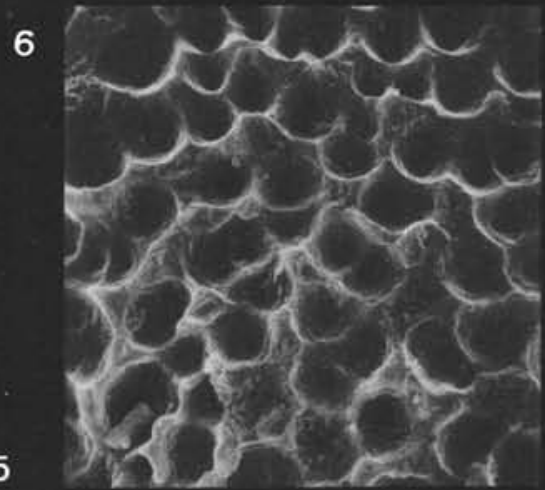
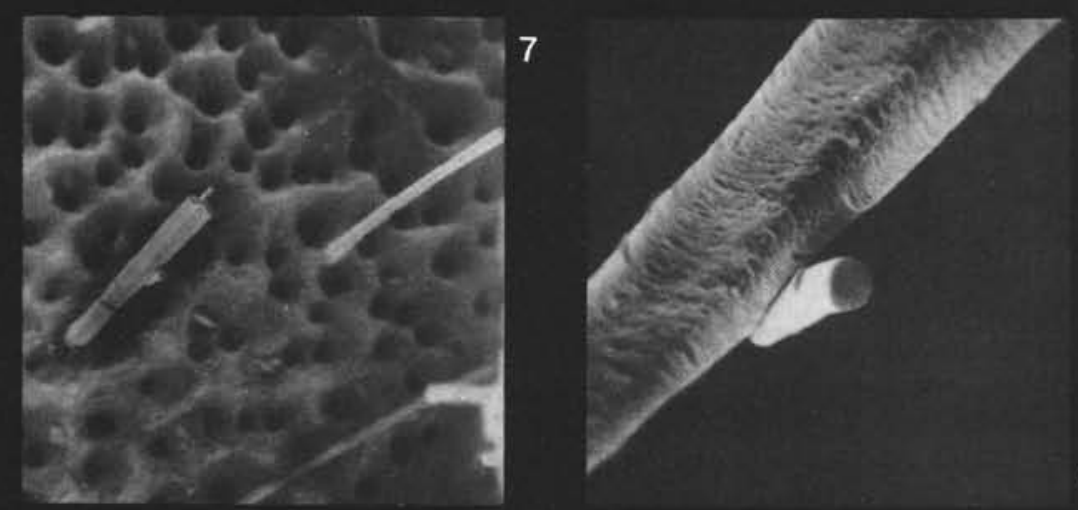

9

8
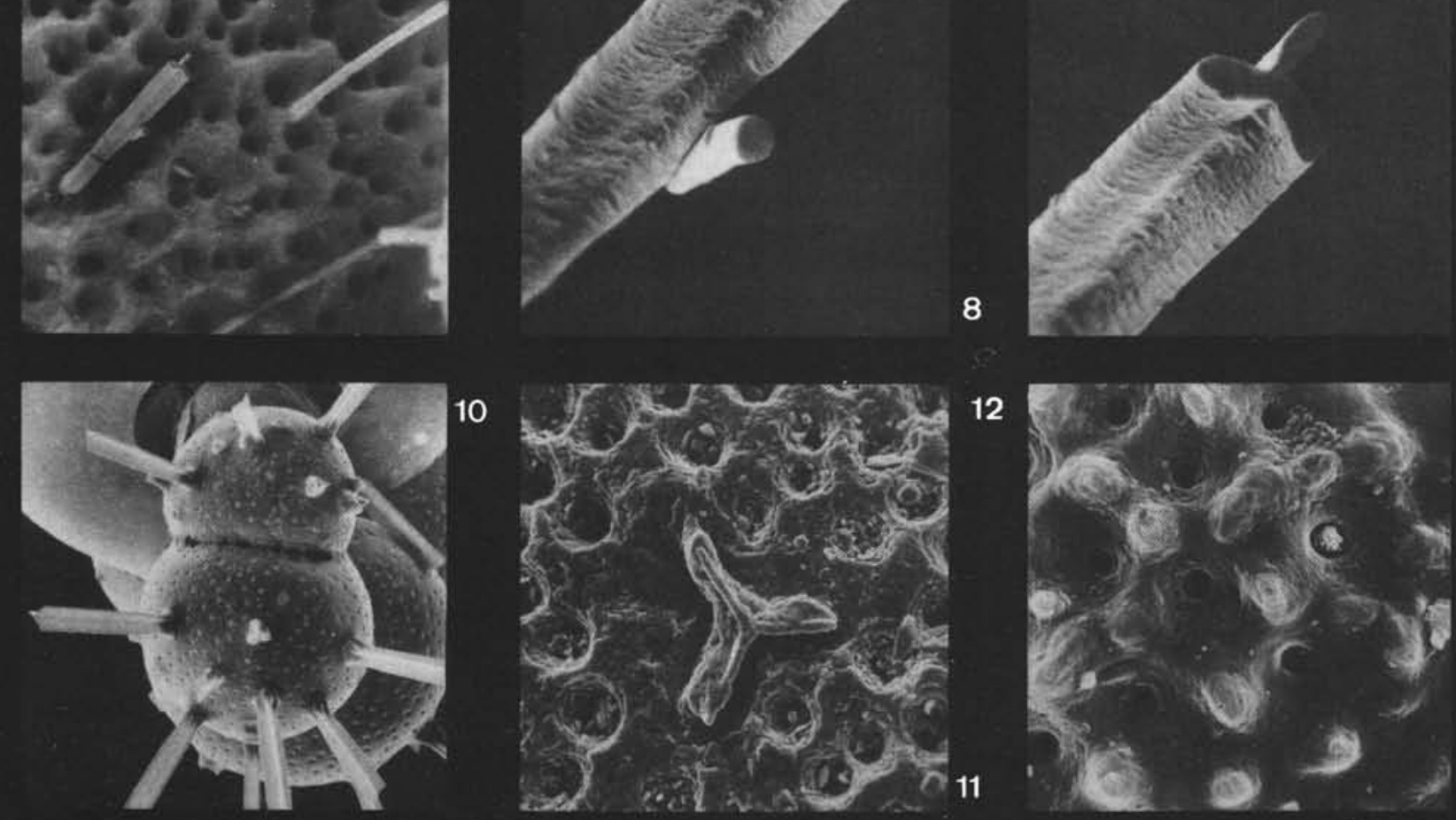


\section{PLATE 14}

Figure 1

Figure 2

Figure 3

Figure 4

Figure 5

Figure 6

Figure 7

Figure 8

Figure 9

Figure 10

Figure 11

Figure 12
Hastigerinella riedeli Rögl and Bolli, n. sp.; older chamber. See Plate 4, Figure 4. 2500X.

Hastigerinella riedeli Rögl and Bolli n. sp.; spines. See Plate 4, Figure 1. 2500X.

Hastigerinella riedeli $\mathrm{Rögl}$ and Bolli n. sp.; aperture. See Plate 4, Figure 4. 1000X.

Orbulina universa d'Orb. See Plate 4, Figure 18. 1000X.

Orbulina universa d'Orb. See Plate 4, Figure 19. 1000X.

Orbulina universa d'Orb. See Plate 4, Figure 21. 1000X.

Globigerinoides ruber ruber (d'Orb.); final chamber. See Plate 5, Figure 4. 1000X.

Globigerinoides ruber ruber (d'Orb.); penultimate chamber. See Plate 5, Figure 4. 1000X.

Globigerinoides ruber ruber (d'Orb.); third last chamber. see Plate 5, Figure 4. 1000X.

Globigerinoides cf. ruber pyramidalis (Van den Broeck); third last chamber. See Plate 5, Figure 6. 1000X.

Globigerinoides ruber pyramidalis (Van den Broeck); older chamber. See Plate 5, Figure 9. 1000X.

Globigerinoides ruber elongatus (d'Orb.); third last chamber. See Plate 5, Figure 11. 1000X. 


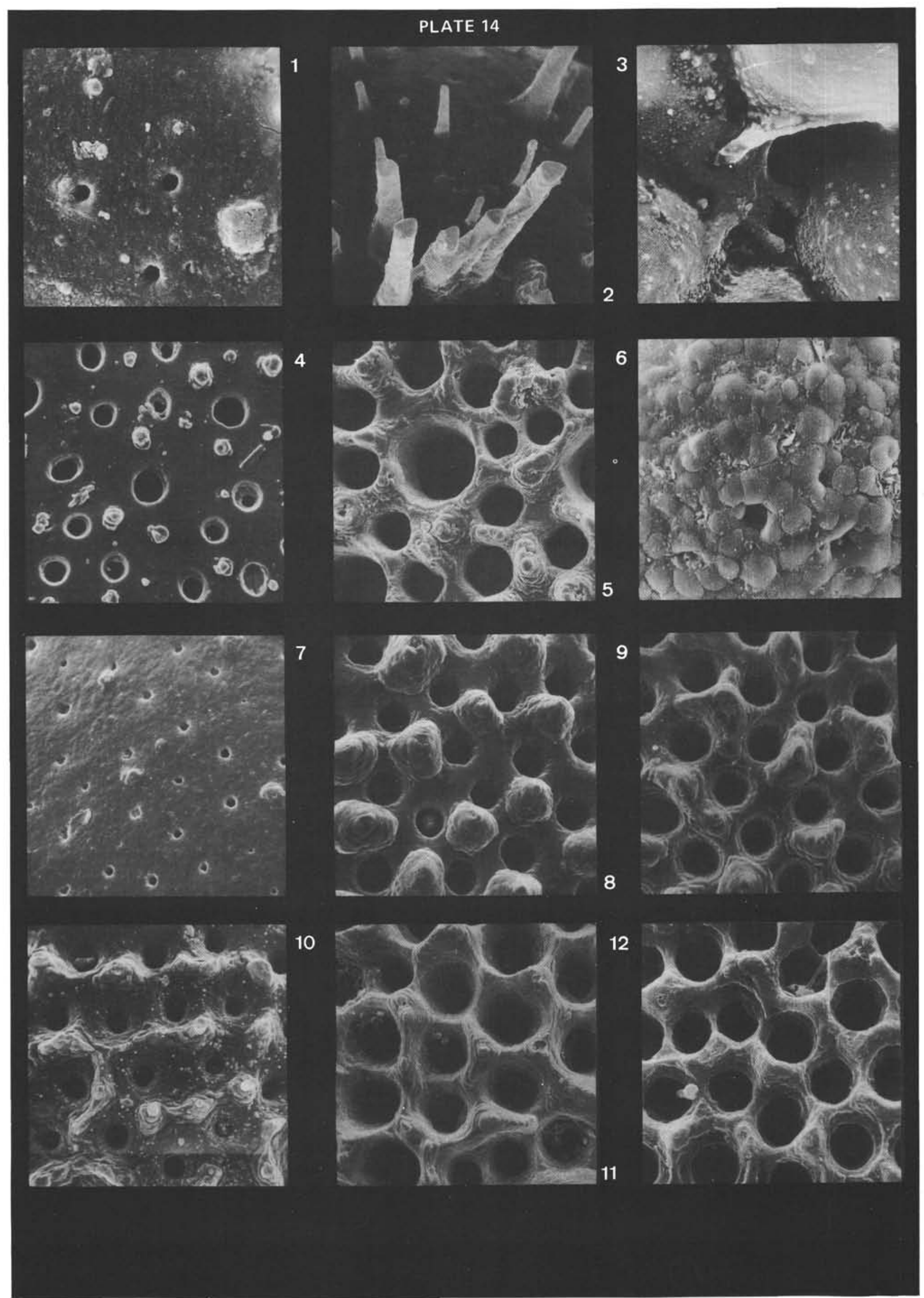




\section{PLATE 15}

Figure 1 Globigerinoides trilobus sacculifer (Brady); final chamber (NMB C-27078). From Site 147, Core 2, Section 1 (top). Globorotalia fimbriata Subzone; Holocene. $1000 \mathrm{X}$.

Figure 2 Globigerinoides trilobus sacculifer (Brady); penultimate chamber. Same specimen as Figure 1. 1000X.

Figure 3 Globigerinoides suleki Bermudez; penultimate chamber. See Plate 4, Figure 23. 500X.

Figure 4 Globigerinita glutinata (Egger); penultimate chamber. See Plate 5, Figure 21. 2500X.

Figure 5 Globigerinita glutinata (Egger); older chamber. See Plate 5, Figure 23. 1500X.

Figure 6

Pulleniatina obliquiloculata obliquiloculata (Parker and Jones); Opened specimen (NMB C-27049). See Plate 15, Figure 9. From Site 147, Core 4, core catcher. Globigerina bermudezi Subzone; Late Pleistocene. $150 \mathrm{X}$.

Figure 7 Globigerinita uvula uvula (Ehrenberg); third last chamber. See Plate 5, Figure 24. 2500X.

Figure $8 \quad$ Globigerinita uvula cf. minuta (Natland); penultimate chamber. See Plate 5, Figure 25. 2500X.

Figure 9 Pulleniatina obliquiloculata obliquiloculata (Parker and Jones); inner chamber. See Plate 15, Figure 6. $750 \mathrm{X}$.

Figure $10 \quad$ Turborotalita anfracta (Parker); third last chamber. See Plate 8, Figure 2. 1000X.

Figure 11 Turborotalita sp.; penultimate chamber. See Plate 8, Figure 12.1000X.

Figure 12 Turborotalita sp.; final chamber. See Plate 8, Figure 13. $2000 \mathrm{X}$. 


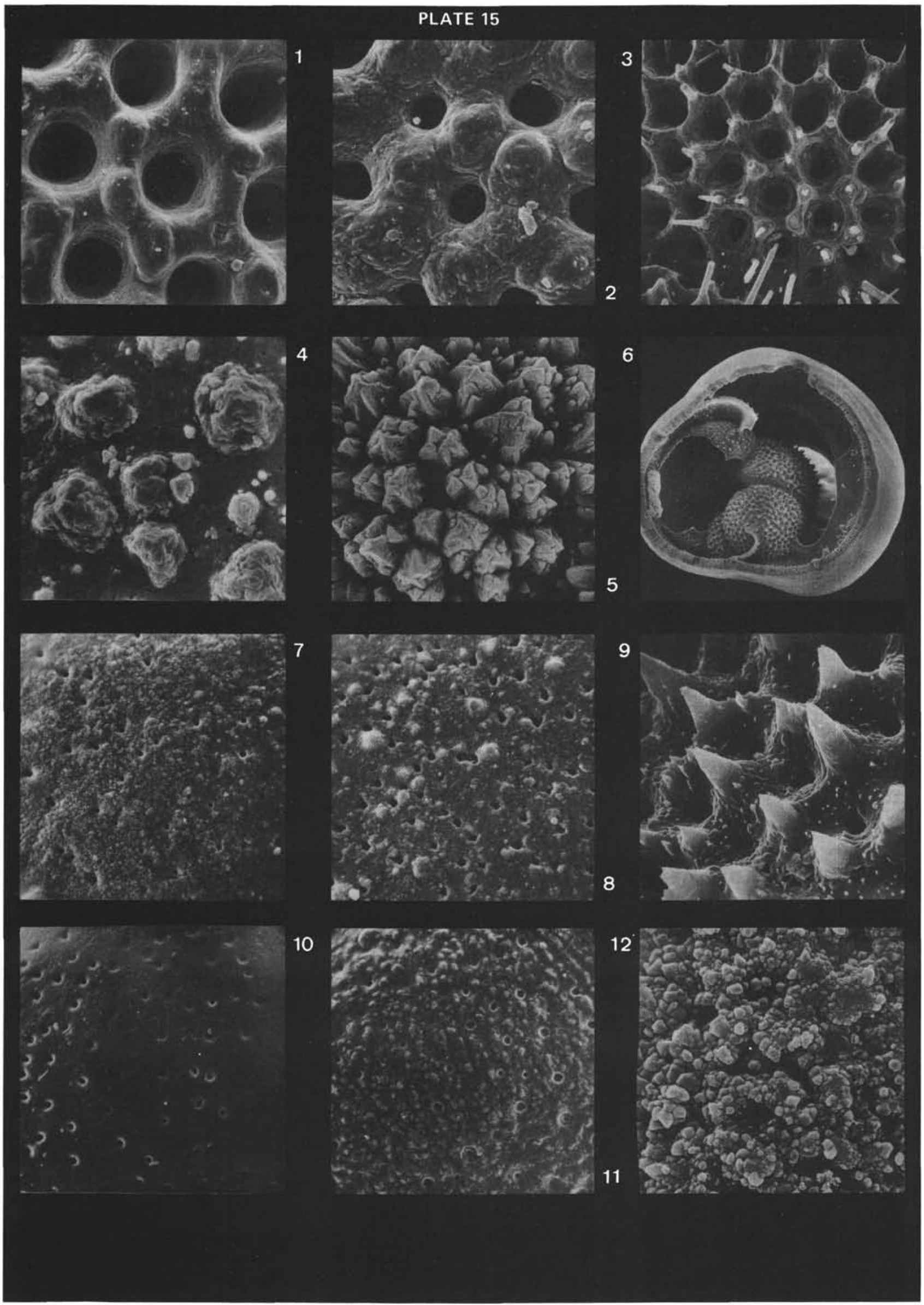




\section{PLATE 16}

Figure 1 Globorotalia bermudezi Rögl and Bolli, n. sp.; penultimate chamber, spiral side. See Plate 6, Figure 16. $500 x$.

Figure 2 Globorotalia bermudezi Rögl and Bolli, n. sp.; penultimate chamber, umbilical side. See Plate 6, Figure 17. 500X.

Figure 3 Globorotalia bermudezi Rögl and Bolli n. sp.; penultimate chamber, umbilical side. See Plate 6, Figure 17. $1000 x$.

Figure $4 \quad$ Globorotalia sp.; penultimate chamber, spiral side. See Plate 7, Figure 4. 1000X.

Figure 5 Globorotalia scitula scitula (Brady); penultimate chamber, umbilical side. See Plate 6, Figure 13. $1000 x$

Figure 6 Globorotalia inflata (d'Orb.); penultimate chamber, spiral side. See Plate 7, Figure 21. 1000X.

Figure $7 \quad$ Globorotalia crassaformis crassaformis (Galloway and Wissler); penultimate chamber, spiral side. See Plate 7, Figure 13. 1000X.

Figure $8 \quad$ Globorotalia crassaformis crassaformis (Galloway and Wissler); penultimate chamber, umbilical side. See Plate 7, Figure 11. 1000X.

Figure 9 Turborotalita iota (Parker; penultimate chamber, umbilical side. See Plate 8, Figure 22. 1000X.

Figure 10 Neogloboquadrina pachyderma incompta (Cifelli); final chamber. See Plate 10, Figure 13. 1000X.

Figure 11 Neogloboquadrina pachyderma incompta (Cifelli); penultimate chamber. See Plate 10, Figure 15. $1000 \times$.

Figure 12 Neogloboquadrina pachyderma pachyderma (Ehrenberg); penultimate chamber. See Plate 11, Figure 4. $1000 x$. 


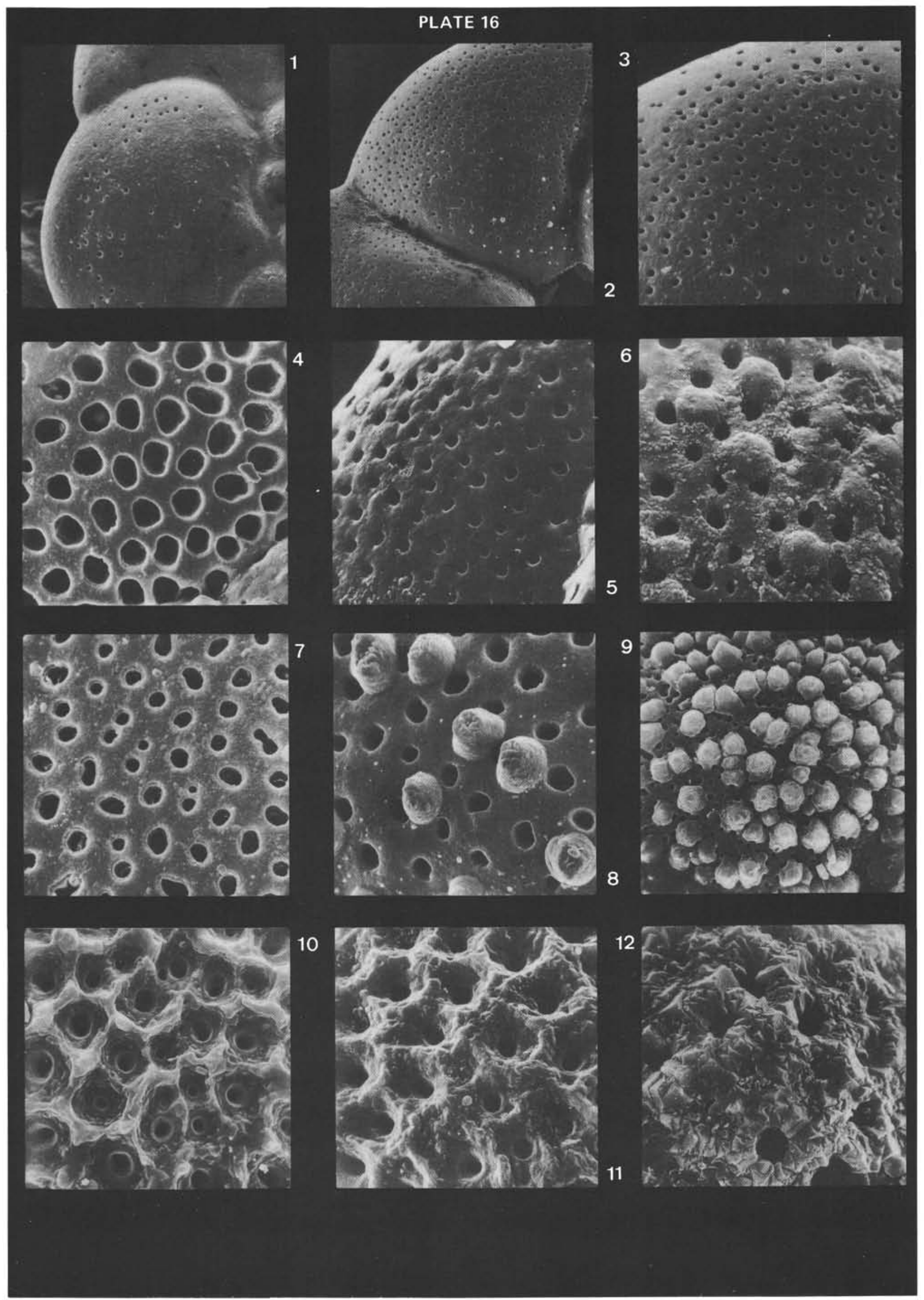




\section{PLATE 17}

Figure $1 \quad$ Neogloboquadrina dutertrei dutertrei (d'Orb); final chamber. See Plate 9, Figure 8.500X.

Figure 2 Neogloboquadrina dutertrei dutertrei (d'Orb); final chamber. See Plate 9, Figure 5. 1000X.

Figure 3 Neogloboquadrina dutertrei dutertrei (d'Orb.); penultimate chamber. See Plate 9, Figure 5. 1000X.

Figure 4 Neogloboquadrina dutertrei dutertrei (d'Orb.); third last chamber. See Plate 9, Figure 8. 1000X.

Figure $5 \quad$ Neogloboquadrina dutertrei dutertrei (d'Orb.); final chamber. See Plate 9, Figure 9. 1000X.

Figure $6 \quad$ Neogloboquadrina dutertrei dutertrei (d'Orb.); penultimate chamber. See Plate 9, Figure 9. 1000X.

Figure $7 \quad$ Neogloboquadrina dutertrei pseudopima (Blow); final chamber. See Plate 9, Figure 13. 1000X.

Figure $8 \quad$ Neogloboquadrina dutertrei pseudopima (Blow); umbilical area. See Plate 9, Figure 15.250X.

Figure 9 Neogloboquadrina dutertrei pseudopima (Blow); penultimate chamber. See Plate 9, Figure 15. 1000X.

Figure 10 Neogloboquadrina dutertrei ssp., bulla. See Plate 9, Figure 11.500X.

Figure $11 \quad$ Neogloboquadrina dutertrei ssp.; final chamber. See Plate 9, Figure 10. 1000X.

Figure 12 Neogloboquadrina dutertrei blowi Rögl and Bolli, nom. nov.; final chamber. See Plate 9, Figure 21. $1000 \times$. 


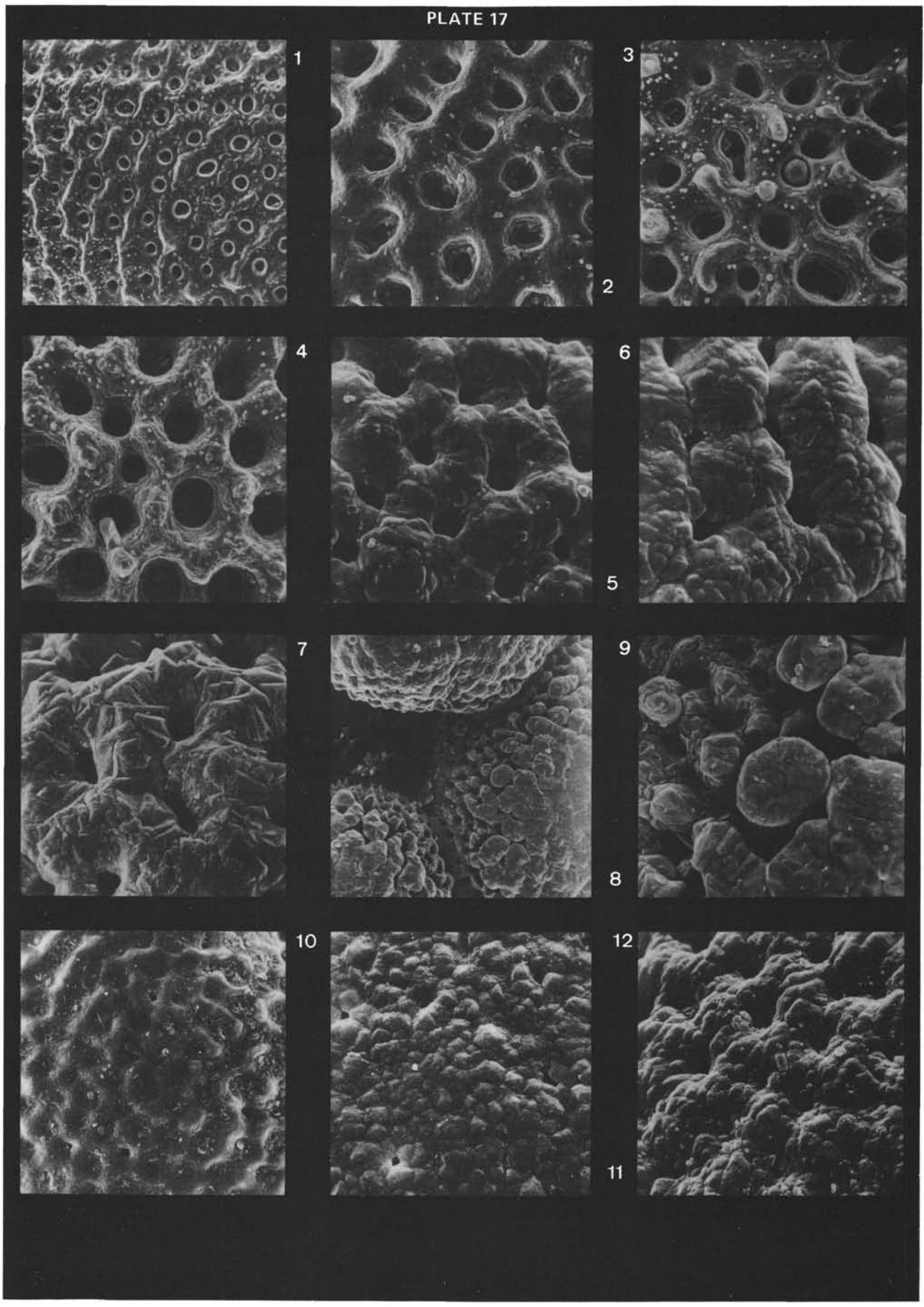




\section{PLATE 18}

Figure 1 Spine from the arms of Ophiuroidea. From Site 147, Core 2, Section 1 (top). Globorotalia fimbriata Subzone; Holocene. 190X.

Figure 2-14 Internal skeletons of Echinopluteus (planktonic larval stage of Echinoidea).

Figure 2: From Site 147, Core 3, Section 1 (100-102 $\mathrm{cm})$. Globigerina bermudezi Subzone; Late Pleistocene. 150X. Figure 3: From Site 147, Core 2, Section $2(141-143 \mathrm{~cm})$. Globigerina bermudezi Subzone; Late Pleistocene. 25X. Figure 4: From Site 147, Core 2, Section $1(140-142 \mathrm{~cm})$. Globorotalia fimbriata Subzone; Holocene. 75X. Figure 5: From Site 147, Core 2, Section $3(99-101 \mathrm{~cm})$. Globigerina bermudezi Subzone; Late Pleistocene. 100X. Figure 6: From Site 147, Core 2, Section 1 (140-142 cm). Globorotalia fimbriata Subzone; Holocene. 100X. Figure 7: From Site 147; Core 2, Section 1 (140-142 $\mathrm{cm})$. Globorotalia fimbriata Subzone; Holocene. 250X. Figure 8: From Site 147, Core 2, Section 3 $(99-101 \mathrm{~cm})$. Globigerina bermudezi Subzone; Late Pleistocene. 300X. Figure 9: From Site 147, Core 2, Section $2(20-22 \mathrm{~cm})$. Globorotalia fimbriata Subzone; Holocene. 150X. Figure 10: See Plate 18, Figure 6 (detail). 1000X. Figure 11: See Plate 18, Figure 6 (detail). 1000X. Figure 12: See Plate 18, Figure 9 (detail). 500X. Figure 13: See Plate 18, Figure 9 (detail). 1000X. Figure 14: See Plate 18, Figure 2 (detail). 1000X.

Figure 15 Spine from the arms of Ophiuroidea. See Plate 18, Figure 1 (detail). 1000X. 
HOLOCENE TO PLEISTOCENE PLANKTONIC FORAMINIFERA, SITE 147

PLATE 18
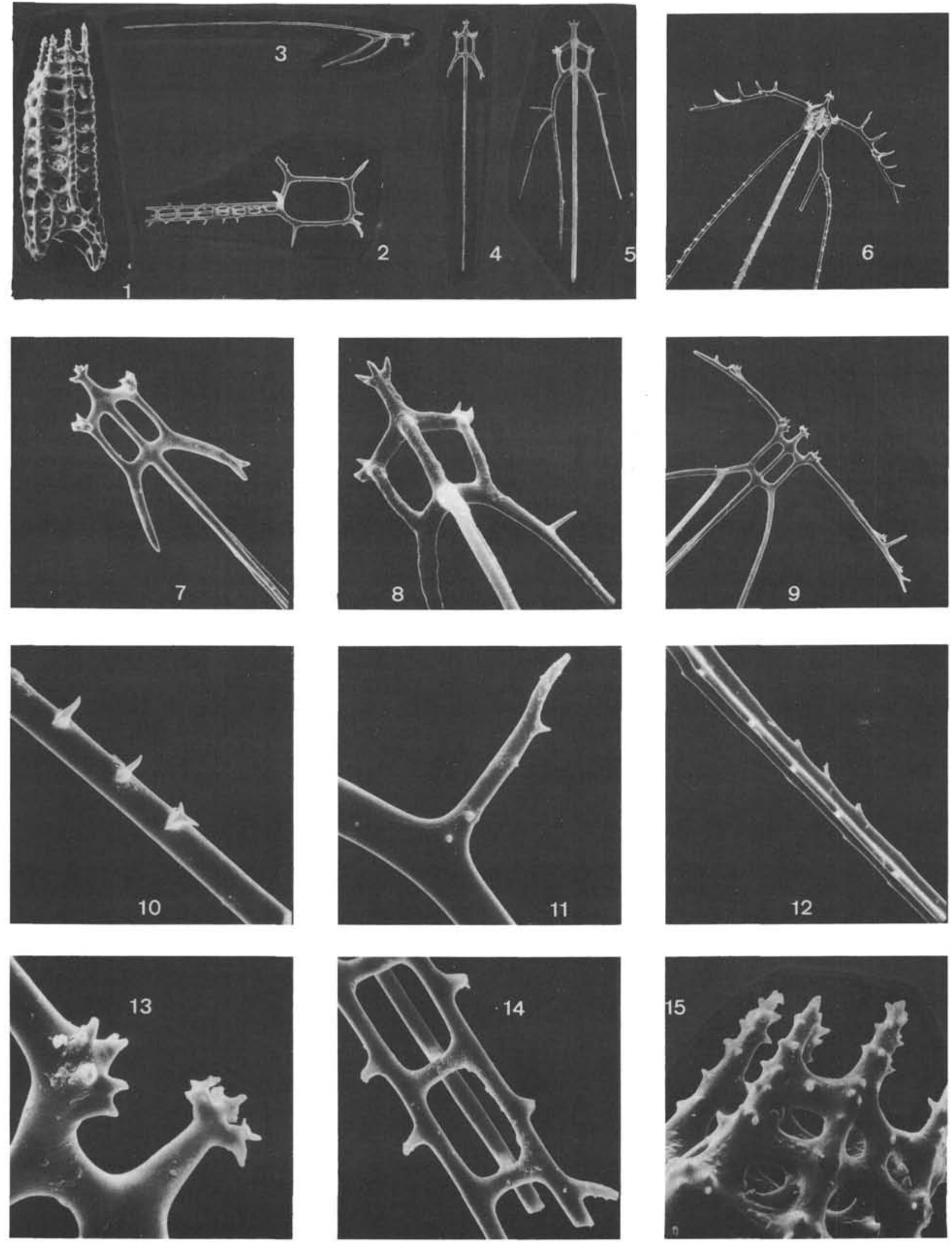